\title{
WestVirginiaUniversity
}

THE RESEARCH REPOSITORY @ WVU

Graduate Theses, Dissertations, and Problem Reports

2006

\section{An analysis of institutions, economic freedom, and the quality of life}

Nathan J. Ashby

West Virginia University

Follow this and additional works at: https://researchrepository.wvu.edu/etd

\section{Recommended Citation}

Ashby, Nathan J., "An analysis of institutions, economic freedom, and the quality of life" (2006). Graduate Theses, Dissertations, and Problem Reports. 2494.

https://researchrepository.wvu.edu/etd/2494

This Dissertation is protected by copyright and/or related rights. It has been brought to you by the The Research Repository @ WVU with permission from the rights-holder(s). You are free to use this Dissertation in any way that is permitted by the copyright and related rights legislation that applies to your use. For other uses you must obtain permission from the rights-holder(s) directly, unless additional rights are indicated by a Creative Commons license in the record and/ or on the work itself. This Dissertation has been accepted for inclusion in WVU Graduate Theses, Dissertations, and Problem Reports collection by an authorized administrator of The Research Repository @ WVU.

For more information, please contact researchrepository@mail.wvu.edu. 


\title{
An Analysis of Institutions, Economic Freedom, and the Quality of Life
}

\author{
Nathan J. Ashby \\ Dissertation Submitted to the \\ College of Business and Economics at \\ West Virginia University \\ in partial fulfillment of the requirements for the degree of \\ Doctor of Philosophy \\ in \\ Economics \\ Russell S. Sobel, Ph.D., Chair \\ Brian Cushing, Ph.D. \\ Stratford M. Douglas, Ph.D. \\ Subhayu Bandyopadhay, Ph.D. \\ William Anderson, Ph.D. \\ Department of Economics \\ Morgantown, West Virginia \\ 2006
}

Keywords: economic freedom, migration, federalism, institutions

Copyright 2006 Nathan J. Ashby 


\title{
ABSTRACT \\ An Analysis of Institutions, Economic Freedom, and the Quality of Life
}

\begin{abstract}
Nathan J. Ashby
The impact of economic freedom on the quality of life is the subject of interest for this dissertation. Three separate studies are conducted. The first of these studies in Chapter 2 analyzes the impact of economic freedom on the quality of life in an international panel data study between 1985 and 2000. It is found that economic freedom and in particular well-defined property rights and limited regulation lead to improvement in the quality of life using the Index of Human Progress, an index made up income, health and education indicators, and access to modern technology for individuals in a given country. Chapter 3 contains the second study, a cross-sectional analysis of migration of individuals between the ages of 20 and 59 in the United States between the lower 48 states between 1995 and 2000. The impact of economic freedom on migration as well as other control variables is measured and it is found that economic freedom has a positive impact on the decision to migrate in aggregate. After decomposing the index into the raw data, it is found that individuals move towards states with less restrictive minimum wages, less restrictive tax rates for the top income group, less unionization, and less dependence on public employment. It also found that individuals migrate towards states with relatively higher expenditures by government. Chapter 4 contains the last of three studies. This essay is an analysis of positive changes in economic freedom on income and income growth for the lowest, middle, and highest quintiles of income in the lower 48 states between 1980 and 2003. It is found that economic freedom has significant impacts on income levels and growth rates for all three groups. However, the results are the strongest for the lowest and middle quintiles. The share of income held by the lowest quintile increases as a result of improvements in economic freedom whereas the same change will lower the share of income held by the highest quintile. It is found that inequality between the highest income quintile and the lowest quintile in the United States is lowered by improvements in economic freedom.
\end{abstract}


Dedicated to Holly 


\section{$\underline{\text { ACKNOWLEDGEMENTS }}$}

I am greatly indebted to my dissertation chairman, Russell Sobel, and his constant willingness to help me achieve this objective. He has helped me turn three simple ideas into a dissertation. He always was prompt to read and revise my papers and provided invaluable suggestions that have guided me as a doctoral student and undoubtedly will be of assistance to me in my future career.

I also should express appreciation to my other committee members Subhayu Bandyopadhyay, Brian Cushing, Stratford Douglas, and William Anderson for their invaluable assistance in helping me to attack the fundamental questions that I sought to answer in this thesis. Pete Leeson, James Lesage, Mehmet Tosun, William Trumbull, Alexei Egorov, and Ronald Balvers have given me assistance and deserve recognition as well.

I have attended school with some very smart people that have helped me get through some tough classes. Fang Wang, my office mate for three years, was very helpful to me in explaining difficult concepts and guiding me through some complicated programming in MATLAB and SAS. Many others have helped me on many occasions, but there are too many to list here.

With sincere gratitude I include my parents, Wayne and Janice, for the many years of hard work in raising me and for always believing in me. They have taught me the important things in life which have been most essential for my success. I would also like to thank Jonathan and Colleen for their willingness to trust a penniless, timid kid to traverse the continent with their daughter toward an uncertain future. Their support for my family has perhaps gone further than they realize in alleviating the stresses of these past years. I am indebted to my brothers David, John, Adam, and Blake, and my sister JoEllen for their love and support they have given me throughout the years.

My children, Savanna and Joshua, although too young to realize it, have done a lot to help me get through this program. A simple smile or laugh when I had a hard day helped bring me down to earth on many occasions and helped me remember that there is more to life than running regressions. I can honestly say that this would have been harder without them.

Most importantly, I must thank Holly, my wife, for putting up with many late nights at the office and some major stress fits before exams. Of her own volition she has spent endless hours in our cramped mobile home with our children. Certainly, she has taken on more than her share of mundane chores, and she has done it with a smile. If it had not been for her encouragement, it is quite likely that I would have packed my bags after my first semester here at West Virginia University and tried my lot at something else. It's a good thing she makes life so much fun or there would have been nothing to offset the misery of my first year of grad school. This Ph.D. is as much a tribute to herif not more - than to me for her patience and understanding during these past four years. 


\section{TABLE OF CONTENTS}

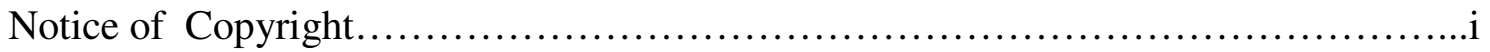

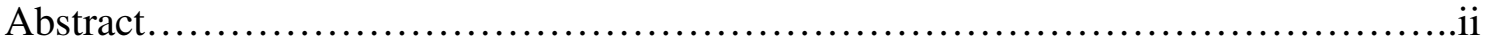

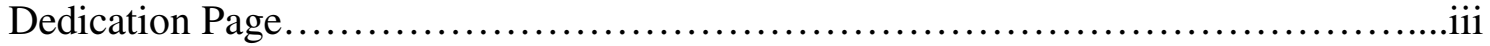

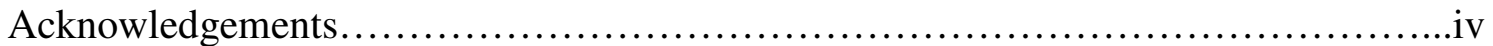

List of Tables and Figures...................................................

Chapter 1: Economic Freedom and the Quality of Life.............................



1.2 What is Economic Freedom............................................

1.3 Economic Freedom as an End........................................... 5

1.4 Economic Freedom as a Means........................................10

1.5 Summary of Contributions......................................... 12

Chapter 2: Property Rights, Institutions, and the Quality of Life: An Analysis of International Panel Data............................................................ 16

2.1 Introduction........................................................ 17

2.2 The Importance of the Institutions in Determining the Quality of Life.......18

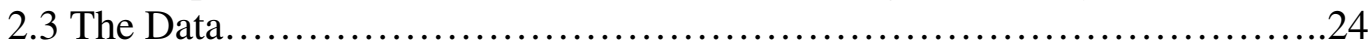

2.3.1 Measurements of Quality of Life..........................24

2.3.2 Measurements of Institutions................................27

2.3.3 Other Variables in the Model...................................29

2.4 Empirical Model................................................... 31

2.5 Empirical Results................................................. 34

2.6 Conclusion.......................................................... 40

Chapter 3: Economic Freedom and Migration Flows Between U.S. States..............41

3.1 Introduction ....................................................... 42

3.2 Review of the Literature...........................................45

3.2.1 Economic Freedom and Market-Preserving Fiscal Federalism.....45

3.2.2 Migration...............................................50

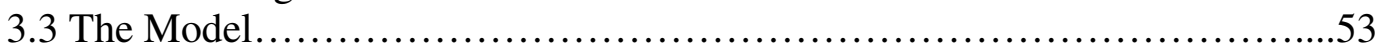

3.4 Empirical Results...................................................63

3.5 Conclusion and Policy Implications.................................. 73

Chapter 4: Income Inequality and Economic Freedom in U.S. States..................74

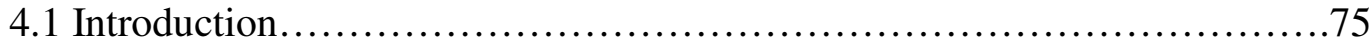

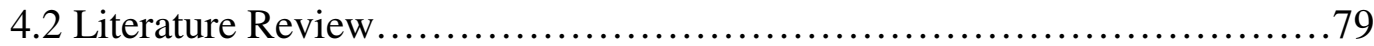

4.3 Data and Methodology............................................... 80 
4.4 Regression Results................................................ 85

4.5 Freedom Components....................................................93



Chapter 5: Summary and Concluding Remarks.................................. 98

5.1 Summary............................................................... 99

5.2 Concluding Remarks............................................. 101



References...................................................................... 114 


\section{LIST OF TABLES AND FIGURES}

\section{TABLES:}

Table 2.1: Descriptive Statistics..............................................32

Table 2.2: Regression Results with IHP as the Dependent Variable.....................35

Table 2.3: Regression Results with IHP as the Dependent Variable and the Economic

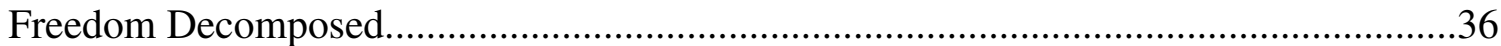

Table 2.4: Regression Results with IHP as the Dependent Variable and the Economic Freedom Decomposed and Government Expenditure from Penn World Tables...........39

Table 3.1: Components of Economic Freedom of North America Index................48

Table 3.2: Economic Freedom Rank 1990-1995 Average............................49

Table 3.3: Descriptive Statistics...........................................62

Table 3.4: GSAR Estimation for Equation 4 with the Log-Odds Ratio of the Migration

Rate as the Dependent Variable.................................................64

Table 3.5: GSAR Estimation for Equation 4 with the Log-Odds Ratio of the Migration

Rate as the Dependent Variable and Economic Freedom Decomposed..................67

Table 3.6: Analysis of a Standard Deviation Increase in the Values of the Variables.....70

Table 4.1: The Impact of Economic Freedom (Level and Changes) on the Lowest Income

Quintile...................................................................... 88

Table 4.2: The Impact of Economic Freedom (Level and Changes) on the Middle Income

Quintile................................................................. 89

Table 4.3: The Impact of Economic Freedom (Level and Changes) on the Highest

Income Quintile........................................................90

Table 4.4: Economic Freedom and Income Inequality: The Ratio of the Share of Income Held by the Highest Quintile to the Share of Income Held by the Lowest Income Quintile

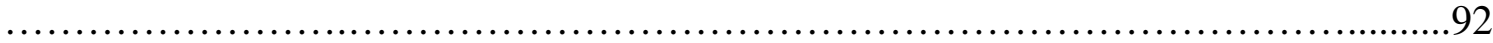

Table 4.5: Economic Freedom Component Areas (summarized coefficient results).....96

Table A.1: Description of Variables Used in Chapter 2..............................104

Table A.2: Correlation Matrix for Institution Measurements......................... 105

Table A.3: List of Countries in Sample Used in Chapter 2 ..........................106

Table B.1: Description of Data and Sources and Description.......................111

Table C.1: Variable Sources and Descriptive Statistics............................115 


\section{FIGURES:}

Figure 2.1: Relationship Between Economic Freedom Components and the Index of Human Progress................................................................33

Figure 2.2: Relationship Between Economic Freedom Components and Index of Human Progress .38

Figure 4.1: The Change in Economic Freedom and Income Growth in the Lowest, Middle, and Highest Income Quintiles (1980-2003).....

Figure 4.2: The Impact of a One Unit Increase in Economic Freedom on Income Levels

and Growth for the Lowest, Middle, and Highest Income Quintiles..................91 Figure A.1: Explanation for the Calculation of the Human Development Index and the Index of Human Progress...................................................... 107 Figure A.2: Algebraic Explanation for the Calculation of the Chain-linked Economic Freedom Component Scores.................................................... 108

Figure A.3: The Areas and Components of the EFW Index........................109 


\section{CHAPTER 1}

\section{ECONOMIC FREEDOM AND THE QUALITY OF LIFE}

“...the forces of the market are just that: They are forces;

they are like the wind and the tides... if you want to try to ignore them, you ignore them at your peril... if you find a way of ordering your life that is compatible with these forces, indeed which harnesses these forces to the benefit of your society, that's the way to go."

-Arnold Harberger, 2000 


\section{CHAPTER 1}

\section{ECONOMIC FREEDOM AND THE QUALITY OF LIFE}

\subsection{Introduction}

In the year 1215 A.D., the original Magna Carta was signed in England by King John conceding rights to landowners by limiting expropriation of property by the monarchy to the consent of Parliament. Although this individual act did not lead to immediately accepted protections for individuals from government coercion-indeed there were many versions of this document during the imminent centuries-it eventually led to the Glorious Revolution in 1688 essentially providing the Parliament veto power over the monarchy and instituting the Bill of Rights. Nearly a century later, on the American continent an even bolder development occurred when the colonists signed the Declaration of Independence demanding autonomy from the English crown. The U.S. Constitution was signed in 1787 , creating the first of many continuing republics in the current world. The Industrial Revolution began in the early $19^{\text {th }}$ Century resulting in an improvement in production never even fathomed prior to that time.

All of these events were different points along hundreds of years of evolution of institutional development. All were building upon their predecessors. Certainly, these events are only discrete symbols of the continuous changes that were occurring through voluntary institutional arrangements and individuals' accumulation of knowledge that were beneficial to society in fomenting the forces of production. Douglass North (1990, 1991) refers to this evolution as path dependence. Such changes are perhaps a function of religious and cultural values and customs. The success of developed nations today can 
be traced through a path of successful decisions that were made throughout centuries of historical precedents.

On the contrary, many less developed nations and the lack of quality of institutions in these can be traced to a less effective pathway of institutional development. Such is the case with many Spanish-colonized nations and the form in which Spain chose to colonize (Acemoglu, Johnson, and Robinson, 2001). The methods used by the Spanish were usually extractive and centralized instead of constructive and decentralized. The evidence of the importance of institutions in development is becoming more widely accepted by economists. What it is that leads nations towards development of quality institutions is a puzzle that remains to be solved. Some societies have gradually improved their institutions throughout the centuries; others at some point have chosen institutional pathways that have resulted in overall disastrous outcomes.

Milton Friedman (1962) suggests that the establishment of institutions of economic freedom is a desirable objective for public policy in and of itself, but that it is also a necessary means of obtaining political freedom and economic wellbeing. For many, economic freedom is merely an ideal, simply an end; for some, it is a necessary condition to ensure the perseverance of democracy and maximize the quality of life of individuals. Even if one does not hold economic freedom as an ideal, there is much evidence that it is desirable to promote such policies in order to achieve other outcomes or economic objectives that would lead to improvements in the quality of life.

The purpose of this dissertation is to discuss and analyze empirically the extent to which institutions of economic freedom enhance the quality of life. This opening chapter will describe the meaning of economic freedom, provide a background on economic 
freedom as an ideal, present a description of economic freedom as an end to other objectives, and give a summary of the three studies contained herein and the contributions that they provide. Although the studies discussed are quite different, the overall theme is consistent.

\subsection{What is Economic Freedom}

Milton and Rose Friedman explained in their book Free to Choose that "... an essential part of economic freedom is freedom to choose how to use our income: how much to spend on ourselves and on what items; how much to save and in what form; how much to give away and to whom,"(1979). James Gwartney and Robert Lawson, authors of the index called Economic Freedom of the World Index, state that important aspects of economic freedom “.... are personal choice, voluntary exchange, freedom to compete, and protection of person and property,"(2004). The Pacific Research Institute states that, "Economic freedom is the right of individuals to pursue their interests through voluntary exchange of private property under a rule of law, and this freedom forms the foundation of all market economies,"(McQuillan, 2004). Numerous other definitions exist in the literature.

Whatever the definition, it is commonly perceived that economic freedom coincides with a competitive free market society which recognizes the right to personal property and the ability to exploit it to one's own advantage as long as such efforts do not conflict with another individual's equal rights. Numerous measurements of economic freedom have been used to make up the different indices of economic freedom. Measurements include government expenditures and ownership of enterprises, indicators 
of the tax rates and/or tax burdens, regulation of the market, freedom in labor markets, the use of monetary policy and inflation volatility, freedom to trade with foreigners, definition of property rights, and wage and price controls among many others. One characteristic that all of these have in common is that each in some way goes hand in hand with the principle of private property rights. In making this statement, it must be made clear what is meant by private property rights. Certainly, property rights imply that individuals are entitled to obtain tangible property through payment or transfer and have legal ownership of all benefits that are created from the given property. In addition, it implies that those holding such rights also bear the external costs imposed on other individuals. This extends to the production activities and intellectual property rights as well. However, individuals also have legal ownership of themselves and to receive through voluntary arrangements remuneration for their labors and innovations.

\subsection{Economic Freedom as an End}

Regardless of the outcomes that result from institutions of economic freedom, it has been argued that such institutions have intrinsic qualities that increase wellbeing. Amartya Sen (1999) cites the example of African American slaves prior to the Civil War in the United States as an example of this point. Although the remuneration of slaves has been demonstrated to be very similar to their non-slave counterpart agricultural laborers, many slaves did run away from their owners. In addition, efforts to employ the slaves in gang labor after they were emancipated yielded no success despite the competitive wages that were offered them. Certainly, the ability and freedom to use their own labor how they saw fit was a tremendous improvement of their overall utility. 
One could explore the writings of philosophers from centuries past to establish the exact birth of this ideal, but it is highly probable that the writings of John Locke (1690) in the late Seventeenth Century had great influence on its acceptance. In his Second Treatise on Government he stated, "Though the earth, and all inferior creatures, be common to all men, yet every man has a property in his own person: this no body has any right to but himself." Further, he claimed that the protection of property is the sole responsibility of government, “...government has no other end, but the preservation of property,"(1690).

The U.S. Constitution contains various provisions that demonstrate the acceptance of this institution by the framers. The latter part of the Fifth Amendment states that an individual shall not be "...deprived of life, liberty, or property without due process of law; nor shall private property be taken for public use, without just compensation." This amendment assures all individuals the right to protection of property through the legal system, and that the government can not expropriate property without paying for it, a legal concept known as eminent domain. It demonstrates that the ideal of private property rights - or at least compensation for property-was greater than any other purpose that the government might have deemed necessary to carry out. Thomas Jefferson apparently considered this to be the case when he stated during his first inaugural address that he believed in a “...frugal Government, which shall restrain men from injuring one another, shall leave them otherwise free to regulate their own pursuits of industry and improvement, and shall not take from the mouth of labor the bread it has earned.,"(Inaugural Addresses, 2001).

As mentioned above, various measurements of economic freedom have been included in indices of economic freedom. Again, in some way these indicators 
demonstrate the extent to which government policy violates the principle of private property rights. The size of government and the level of taxation are commonly considered in such measurements. The government must surely spend and tax at least in order to maintain the basic institutions and legal structures to maintain and protect property rights. However, taxes are not voluntary and are a claim on the property of individuals. A tax on land to some extent diminishes an individual's right to that property as well as a tax on labor violates that individual's right to obtain the fruits of his/her labors.

Regulation by the government of private industry and even government ownership of industries violates the principle of property rights in many ways. Heavy regulation inhibits or even prohibits firms from producing goods and services that will increase their profits and the value of their property while restricting the scope of the use of such goods. At the same time, they violate the consumer's ability to benefit from the availability of goods and services that would increase their quality of life had such goods been available. Many government agencies have been formed in the United States and around the world in the name of benefiting the consumer, but often fail to yield intended objectives. Regulation of the railroad, airline, and trucking industries usually have resulted in higher prices for consumers and a higher concentration of unionization. The Food and Drug Administration was formed to prevent "dangerous" drugs from being introduced to the market by requiring extensive testing. However, many argue that the result has been more to slow the introduction of drugs that could have saved lives or 
alleviated pain and suffering had they been introduced earlier. ${ }^{1}$ Recently, it has come to the attention of the Wall Street Journal that Tenefovir, a drug that has been known to prevent HIV since 1995, has been kept from the public for many years due to FDA regulation (Hamilton and Chase, 2006). This would appear to support the allegations that regulation is more motivated by politics than anything else. An alternative non-caloric sweetener, Stevia, which is grown in Paraguay, has been argued by many to be a much healthier alternative to domestic sugar (Das, Das, Murphy, Punwani, Nasution, and Kinghorn, 1992; Yamada, Ohgaki, Noda, and Shimizu, 1985). However, the sugar lobby — as usually is the case- - has been more effective in protecting its interests than the health advocates. For years Stevia had been labeled as an illegal drug by the FDA solely based on a controversial 1968 study which suggests that it reduces fertility in women (Planas and Kuc, 1968). Due to the passage of the Dietary Supplement Health and Education Act, it can now legally be sold in the United States. But, only as a "supplement"; not as a "sweetener."

To the extent that individuals are allowed to offer their labor voluntarily in exchange for an agreed upon wage, they are exercising their right to utilize property rights for their own wellbeing. Policies that limit this ability such as minimum wage laws, unionization, strict licensing requirements, or a high percentage of government employment as a percentage of total employment reduce economic freedom and violate the principle of private property rights.

\footnotetext{
${ }^{1}$ Friedman explain the reason for this. The cost that the FDA bears if someone is killed by a dangerous drug may be enormous. However, if many people die due to a drug not being available on the open market, the cost borne by the agency is likely to be minimal.
} 
Government policies with respect to trade can greatly inhibit the ability to utilize property to one's benefit. Excessive tariffs and quotas may benefit individuals in those protected agencies in the short run. Yet such policies curtail firms in foreign countries from maximizing the gains from their property. Likewise, they indirectly create market power in the hands of domestic industries. Thus, domestic consumers and producers must pay higher prices for goods and services and have less selection to choose from. Whenever monopoly is present, it reduces the ability of individuals to benefit from voluntary exchange. Policies that promote such market power arbitrarily transfer the value of property from some groups to others.

The government has the capability of determining the value of the currency in the economy. By printing money at a high rate it increases the price level and reduces the value of money and all assets denominated in that currency. All financial property owned in that currency will diminish in purchasing power. In addition, volatility in the rate of money growth makes it difficult to make informed decisions and arbitrarily transfers property between lenders and borrowers. Thus, the use of inflationary and volatile monetary policy is a violation of the principle of property rights and reduces economic freedom.

Many other variables used in indices of economic freedom could be discussed and a reasonable relationship between economic freedom and the principle of private property rights would be found. 


\subsection{Economic Freedom as a Means}

Ideals aside, institutions of economic freedom are also a means in obtaining other objectives such as political freedom or economic prosperity. Milton and Rose Friedman wrote that economic freedom is necessary condition for political freedom and prosperity, “...we know of no society that has ever achieved posterity and freedom unless voluntary exchange has been its dominant principle of organization,"(1979).

On this subject, the Nobel Laureate and Austrian scholar Friedrich von Hayek (1944) wrote in the Road to Serfdom,

"It is now often said that democracy will not tolerate 'capitalism'. If 'capitalism' means here a competitive system based on free disposal over private property, it is far more important to realize that only within this system is democracy possible. When it becomes dominated by a collectivist creed, democracy will inevitably destroy itself."

These arguments concur with the position that a democracy can not be maintained unless individuals are free in relation to economic matters. The direction of causality should generally go from economic freedom to political freedom. Milton and Rose Friedman (1979) give anecdotal accounts demonstrating this fact. The institution of property rights arguably instigated a movement towards political freedom that resulted in the Revolutionary War and the creation of the United States of America. South Korea's transformation towards democracy was induced by capitalism that was put into place by a dictator. On the other hand, Singapore continues to be a dictatorship today and political freedom is minimal, but this has apparently not been a threat to the economic freedom of its constituents. In general, there have been some attempts to demonstrate this direction 
of causality empirically, and these have been positive (Far, Lord, and Wolfenbarger, 1998). However, since this is a long-run phenomenon, it will take some time to answer this question satisfactorily.

Simultaneous to the idealistic pronunciation of freedom on the American continent was the publication of Adam Smith's Wealth of Nations. Ideals aside, Smith was attempting to demonstrate that free market institutions actually are beneficial to society, "It is not from the benevolence of the butcher, the brewer, or the baker, that we expect our dinner, but from their regard to their own interest,"(1776). In other words, in a society that honors individual private property rights economic outcomes that are beneficial to society in general will emerge. Nations that voluntarily adopt such institutions will generally be wealthier and more developed as a result of the incentives provided to its residents.

Contemporary economists have carried out many empirical experiments to discover whether this is in fact true. Do institutions of economic freedom increase income and the rate at which an economy increases in productivity? The evidence appears to be affirmative. Do these policies result in lower poverty rates, higher literacy rates, and greater health of individuals? Studies seem to indicate that this also is the case. The contributions of this dissertation are three studies that further analyze the effect that economic freedom has on the quality of life. These studies will be discussed in more detail in Chapters 2 through 4. 


\subsection{SUMMARY OF CONTRIBUTIONS}

Chapter 2 is an analysis of panel data of 78 countries and the impact of economic freedom on the Index of Human Progress or the IHP (Emes and Hahn, 2001). The IHP is a measurement constructed by the Fraser Institute similar to the Human Development Index or HDI (UNDP, 1995, 2001, 2003) that considers additional measurements of quality of life beyond income, life expectancy, and health indicators; it also arguably a better measures improvements through time. In particular, the IHP includes the attainment of technological goods such as televisions, radios, and telephone services by country. It better measures progress through time by measuring the improvement of each country using the base year of 1975 .

The Economic Freedom of the World Index (Gwartney and Lawson, 2005) constructed by the Fraser Institute is regressed on the IHP along with other institutional measurements for the quality of government and the rule of law from the International Country Risk Guide. The panel data includes data from the years 1985, 1990, 1995, and 2000. After controlling for possible geographic impediments to development such as ethnic differences, tropical location, landlocked location, and degree of urbanization, it is found that economic freedom significantly impacts quality of life using this measurement. Further regressions analyze the impact of the economic freedom components on the quality of life. It is found that sound property rights and limited regulation are significant determinants of quality of life. This study adds to the plethora of evidence of the benefits of economic freedom in obtaining economic outcomes and is one of few to analyze the different components of the index. 
Chapter 3 is an analysis of the impact of economic freedom on migration flows between the lower 48 states. The index used for this analysis is the Economic Freedom of North American Index (Karabegovic and McMahon, 2005) also constructed by the Fraser Institute. Although the evidence of the benefit of economic freedom in income levels and growth is significant, there are no published studies analyzing the impact of economic freedom on the decision to migrate. This is perplexing given that the decision to migrate is the result of individuals manifesting their preferences and such a study could have interesting policy implications. Many have suggested using migration as an indicator of quality of life enhancement. Using a gravity model which accounts for spatial effects it is determined that economic freedom indirectly impacts migration flows for individuals between the ages of 20 and 59 through the channel of income and employment growth. In addition, this study analyzes the raw data for eight of the ten measurements to determine how individuals react in aggregate to different policies. Interestingly, all economic freedoms do not have the same impact. Measures such as higher government consumption and social security payments-which would tend to reduce economic freedom according to the index used in this study—are significant in attracting migrants. Consistent with the index as a whole, however, states with lower marginal tax rates for the highest income group and high income thresholds for these taxpayers, less restrictive minimum wage laws, a smaller percentage of employees in the public sector as a percentage of total employment, and a lower degree of unionization are all significant in attracting migrants as well. This study is based heavily on Ashby (2007). This chapter will discuss these results and the implications with regards to fiscal 
federalism and the preservation of the market mechanism through economic decentralization.

Chapter 4 is based on Ashby and Sobel (2006). This chapter analyzes how economic freedom levels in 1980 and economic freedom changes since that time have impacted individuals in different income groups by U.S. state. A handful of studies exist that analyze the impact of economic freedom on equality measures such as the Gini coefficient or the share of income held by the poorest income earners relative to the wealthiest. In particular, Berggren (1999) analyzes the impact of economic freedom changes between 1975 and 1985 and levels on some of these measures for a cross section of countries. Scully (2002) finds that higher levels of economic freedom are significant in improving income for all five income quintiles at the international level. The analysis in Chapter 4 will conduct similar tests as well using the Economic Freedom of North America Index to analyze the impact of economic freedom changes and levels between 1980-1982 to 2001-03 on measurements of income for different groups. It is found that positive economic freedom changes positively impact income growth for the lowest and middle income quintiles during this period. The same outcome is found for high income earners. However, this finding is not as robust. Similarly, it is found that economic freedom significantly impacts income levels for the lowest and middle income quintiles, but the results are not as strong for the richest Americans.

The last set of regressions analyzes the impact of economic freedom changes and levels on the share of total income held by the poorest individuals and find the relationships to be positive and significant. These results provide interesting new insights to the benefit of economic freedom. In particular, it appears that the poorest individuals 
tend to benefit greatly from policies that promote voluntary exchange. Most importantly, it is found that inequality is reduced by positive changes in economic freedom.

Finally, Chapter 5 will summarize the results presented herein and provide concluding remarks. 


\title{
CHAPTER 2
}

\section{PROPERTY RIGHTS, INSTITUTIONS, AND THE QUALITY OF LIFE: AN ANALYSIS OF INTERNATIONAL PANEL DATA}

\author{
"Where you live should not decide whether you live or \\ whether you die."
}

-Paul Hewson (AKA Bono), 2004 


\section{CHAPTER 2}

\section{PROPERTY RIGHTS, INSTITUTIONS, AND THE QUALITY OF LIFE: AN ANALYSIS OF INTERNATIONAL PANEL DATA}

\subsection{Introduction}

The amount of literature on the effect of economic institutions-in particular, economic freedom — on growth is significant. The evidence seems to strongly favor sound property rights and its positive effect on economic growth. However, there has been criticism of the use of growth in GDP per capita as a measurement of overall well being or quality of life (Bauer, 2000; Sen, 1999). Such criticism has been rejoined by various studies that have demonstrated that economic freedom positively influences other measurements of life satisfaction such as human poverty measures, literacy, overall education, life expectancy, and mortality rates (Norton, 2003; Esposto and Zaleski, 1999).

This analysis seeks to contribute to these studies in two ways. First, alternative measurements of quality of life from the United Nations and the Fraser Institute will be discussed. The Human Development Index (HDI) has been used by the United Nations and is a weighted index measuring income, education, and health of 162 countries (UNDP, 1995, 2001, 2003). This study will use the Index of Human Progress (IHP) which includes additional indicators of wellbeing including the attainment of technological goods (Emes and Hahn, 2001). It also is a better measurement of how countries progress through time. Results of a similar study that analyzes the effect that property rights have on quality of life using the Economic Freedom of the World Index (Gwartney and Lawson, 2005) and data from the International Country Risk Guide (Political Risk Services, 2004) will be compared to results obtained using the IHP. 
The Economic Freedom of the World Index (EFW) is made up of five subcomponents measuring the size of government, property rights policy, monetary policy, trade policy, and regulation (Gwartney and Lawson, 2005). The second contribution will be to regress these components on the IHP to analyze the specific effect that each of these components on quality of life. Decomposing the index has been attempted in other studies dealing with economic growth (Ayal and Karras, 1998; Carlsson and Lundstrom, 2002; Heckelman and Stroup, 2002), but this is the first attempt to determine the effect that they have on other measurements of well being suggested herein.

The format for the remainder of this paper will be as follows. The following section will discuss the importance of quality institutions in development and arguments dealing with property rights and other free-market policies and why they are important for economic development. Next, the various data gathering sources will be described in minor detail, and the measurements that will be used in this study will be discussed. Section 2.4 will explain and interpret the theoretical model and the regressions for this study. The significance of these results will be analyzed. Finally, the paper will terminate with concluding remarks and important implications of the study.

\subsection{The Importance of the Institutions in Determining the Quality of Life}

Neoclassical models have prevailed in economic literature for decades. This is not without good reason since such models appear to have been somewhat successful at explaining economic outcomes in developed nations. Since developed nations generally have better quality institutions, models that demonstrate that economic outcomes might 
be improved at the margin through greater capital accumulation and improvements in technology have been useful. Although some of the assumptions of neoclassical economic theory may not hold in the extreme such as individuals always acting rationally, the premise for individuals' and firms' maximizing behaviors, and independent action of agents on all fully available information, the outcomes in developed nations are relatively consistent with many neoclassical predictions.

However, such models which ignore the importance of quality institutions, have not been as useful at explaining economic outcomes in the developing world. Transaction costs are sometimes implicitly assumed to be zero or extremely low in neoclassical theory. In reality transaction costs are always present and will be particularly high where poor institutions provide incentives for individuals to spend their time in costly activities that provide no benefit to society. Where the institutions of a given nation fail to create the incentives and responses that are predicted by neoclassical models by any proximity to its assumptions, neoclassical theory fails. In the presence of significant transaction costs, a well-functioning institutional structure is the ever important precursor to obtaining economic prosperity.

North (1990) defines institutions as the "framework in which human interaction takes place." He discusses the importance of informal and formal institutions (North, 1991). Successful institutions — be they economic or political—will provide an incentive structure that leads to productive endeavors that enhance the welfare of individuals as well as the society as a whole. Such institutions evolve through history and are not easily passed on to developing nations. For instance, North demonstrates the path dependence of British-colonized nations that allowed these to be successful and the evolution of 
property rights that had occurred throughout the earlier centuries in the parent nation. On the contrary, he argues that institutions for Spanish-colonized countries have not been very effective and traces this to the inability of Spain to adopt effective institutions at that time and during the years previous to colonization. Indeed, Spain lost the standing that it had once held in the world in the imminent centuries to Britain. Latin American countries continue to lag behind British-colonized nations such as the United States, Australia, New Zealand, and in later centuries, Hong Kong. ${ }^{2}$

Barro (1994) finds that institutions of democracy are important for countries at lower levels of political freedom. However, it is found that after a moderate level of political freedom is obtained, growth is depressed. This is due to the costs of rent seeking and other costs from collectivization that allocate resources towards less productive endeavors.

The extent to which institutions of property rights enhance wellbeing depends on the dichotomy between "rule space" and "policy space" (Scully, 1997). The former is determined by the extent to which property rights are defined through the construction of constitutions, laws, or other legal structures. The policy space, therefore, considers the actual course of action adopted by a government to uphold and facilitate the full benefits of a well-defined structure of property rights. It is therefore argued that these two separate but essential mechanisms must be in place in order for institutions to lead to welfare-augmenting productive activities.

\footnotetext{
${ }^{2}$ One might point out to the fact that many of the colonies that Britain settled have not done so well such as India, the Gold Coast (Congo), and various African nations. Acemoglu, Johnson, and Robinson (2001, 2002) claim that Britain had two different colonizing strategies. One strategy is for long-term settlement and the other is extraction. It is argued by these that the latter strategy has resulted in institutions that have been perpetuated through time and this explains why these face much difficulty in developing their economies.
} 
Epstein (1985) introduced a paradigm through which the welfare effects of property rights can be tested. When measuring the effectiveness of the institution of property rights, the measurement of success is the extent to which the social pie expands as a result of such institutions. In other words, the initial distribution of the pie is not so much a concern, but the extent to which property rights induce an increase in the quality of life for all individuals. This concept coincides with the Pareto principle that institutions are successful if they result in making individuals better off without making anyone worse off. In a stricter sense, the Pareto principle implies that everyone should experience an improvement in their wellbeing. This conflicts with the view of those that perceive property rights as a social ill which necessarily leads to exploitation of the poor and wide gaps in social equality. ${ }^{3}$

Well-defined property rights enable individuals to gain from economic activities and hence create incentives for productive endeavors. The existence of these institutions is necessary for individuals to be willing to make contracts and carry them out. However, in order for such institutions to be effective, the mere existence of such rights does not suffice. Of necessity is the ability to enforce agreements and contracts. The ability to obtain a right to property should be stripped of bureaucratic redundancy in order to reduce the costs. The creation of property rights, if done improperly, will not result in empowerment of individuals and may indeed lead to worse conditions for many of these. North (1991) suggests that a secure property rights structure entails a judicial system that permits lower costs of making contracts and flexible laws which allow various organizational structures.

\footnotetext{
${ }^{3}$ Although Berggren (1999) finds that increases in economic freedom and property rights coincided in more equality between 1975 and 1985 .
} 
De Soto (2000) describes many problems in developing functional institutions of property rights. Entrepreneurs seeking to obtain financial capital are greatly curtailed by the inability to collateralize legitimately recognized titles. This results in 'dead capital', the inability to use assets to produce capital. It is estimated that 70 percent of credit received by new businesses is obtained by using formal titles as collateral. The main contribution made by De Soto is to point out that the mere legal existence of property rights is not a sufficient condition for economic prosperity; institutions of property rights must be packaged with few bureaucratic impediments.

The Economic Freedom of the World Index (Gwartney and Lawson, 2005) is made up of five components which measure different institutions. These institutions are the size of government, property rights and legal structure, money and inflation, trade freedom, and regulation. These institutions should be placed mostly in the "policy space", although one could possibly argue that property rights might be included in the rule space. These indices are made up of averages of various indicators. Although one of the indicators seeks to measure property rights in a more direct form by analyzing protection of intellectual property and impartiality of the courts, all of these are indirectly related to the principle of property rights. As government consumption and government ownership increases, the property right of individuals to receive the benefits of the use of their property is transferred from the private sector to the government whether it be through taxation or government ownership of enterprises. Unstable monetary policy increases uncertainty on the part of property owners with regards to the value and profitability of their assets. When the growth of the money supply is high and volatile, it arbitrarily allocates gains from property between borrowers and lenders. 
Less restrictive trade policy benefits domestic consumers in that it allows them to purchase the cheapest and/or best quality goods that are available. On the contrary, more restrictive trade policies encourage inefficiency in production in that domestic producers face little or no pressure from foreigners, pressure that would help foment specialization of labor by domestic producers and development of better technology and products domestically. Such policies might be high tariff rates on imported goods, import quotas and other non-tariff barriers, exchange rate controls, and excessive controls over capital markets. These restrictions are limitations on the private rights of producers to allocate their resources towards economic gains that benefit them as well as their consumers.

Finally, regulation of entrepreneurial opportunities, credit markets, and labor markets inhibit individuals from buying and selling privately-owned factors of production at mutually beneficial quantities and prices. Bauer (1946) demonstrated how regulation of the Malayan rubber industry in the 1930s led to substantial underproduction adversely affecting poor small holders. Regulation is usually justified in politics on the basis of protecting the consumer from unfair pricing power and unsafe products. However, it has been demonstrated that the very industries being regulated are quite often the ones that stand to benefit the most. Stigler (1971) discussed a theory of regulation and demonstrated that efforts to regulate railways, trucking, medical, and various other industries led to restrictions to entry and higher than normal wages. Government control of prices and wages invariably results in costly misallocation of resources by inducing persistent underproduction and underutilization of economic factors of production.

In addition to the rule space and policy space, there is one more type of institution that should be included. The quality of government is a significant determinant of the 
effectiveness of the rules and policies that are put in place. When the formal and informal institutions of government involve high levels of corruption and bureaucracy, the ability of the rules and policies to result in effective outcomes might be diminished. If the very individuals in charge of the rules and policies are not willing to enforce or apply these to themselves, they will likely not result in an efficient institutional structure. However, if institutions function properly opportunism by government officials will be more limited due to the checks on government from quality political institutions. Therefore, it would be expected that these would be highly correlated with good institutions and policies. Nevertheless, the estimates will control for these factors separately.

\subsection{The Data}

\subsubsection{Measurements of Quality of Life}

Numerous measurements have been used to gauge the economic effects that result from well-defined property rights. There are at least twenty nine attempts to assess the effect that property rights and economic freedom have on economic growth or per capita income across nations. Most of these studies have demonstrated the relationship to be positive. However, the use of income as a measurement of quality of life has been criticized. Bauer (2000) demonstrates the perversity in the implication that can be derived when income per head is used as an indicator of the quality of life given by the fact that the birth of a calf will increase national income per head whereas the birth of a human will reduce it. In addition, Sen (1999) explains that there is certainly an increase 
in wellbeing due to the longevity of life, and thus quality of life can not merely be measured by the accumulation of wealth and income.

There have been some efforts to remedy this fissure in the literature. Norton $(1998 ; 2003)$ uses the standard measurements of well being used by the United Nations (UNDP, 1999, 2001, 2003), the Human Development Index (HDI) and the Human Poverty Index (HPI). Both the HPI and the HDI range between zero and one hundred. A high HPI value represents a low quality of life whereas a high HDI value represents a high quality of life. The HDI consists of three components: health, education, and income per capita. The subcomponents of these indices measure life expectancy, education, literacy, probability of living to age 40 , access to safe water and health services, adult literacy, and the portion of children that are underweight have also been used as dependent variables (Norton, 2003; Esposto and Zaleski, 1999). For the most part, the relationship between the measurements of well being and property rights has been positive and significant. However, due to the limited availability of sample periods, the direction of causality remains to be seen. ${ }^{4}$

The Index of Human Progress (IHP) developed by the Fraser Institute is an alternative to the HDI (Emes and Hahn, 2001). It consists of four main components also: health, technology, education, and income. One problem that may result from use of this measurement is the fact that six additional indicators in calculating these sub indices are required thus reducing the sample size. In all there are 162 countries for which the HDI

\footnotetext{
${ }^{4}$ Far, Lord, and Wolfenbarger (1998) obtained positive results demonstrating that economic freedom causes economic growth. However, due to the short amount of periods available it is difficult to consider the results as conclusive
} 
is calculated and 128 for the IHP. The index is calculated for 1985, 1990, 1995, and 1999. Since the year 2000 will be needed for this analysis, the 2000 IHP is imputed by measuring the rate of change between 1995 and 1999. In the year 2000, Luxembourg, Switzerland, and the United States have the highest IHP values, whereas Niger, Mali, and Cyprus have the lowest IHP values. In the year 1985 Niger, Mali, and Senegal had the lowest IHP values, and Switzerland, the United States, and Japan had the highest values. The appendix includes a more specific explanation as to how the two different indices are calculated for comparison's sake.

There is a positive correlation between well-defined institutions of property rights and the extent to which individuals in a nation are able to obtain the basic needs of life. This relationship would seem to fail to reject the implications suggested by Epstein that private property rights tend to expand the social pie. An interesting question to pose would be to what extent these countries benefit from the adoption of advanced technologies that might enhance the quality of life through enhancing leisure. Consider a continuum of goods from $\mathrm{x}_{1}$ to $\mathrm{x}_{\mathrm{L}}$. Let $\mathrm{x}_{1}$ represents the most essential good for survival. This good might be clean water. Let $\mathrm{x}_{\mathrm{z}}$ represent the good that is least essential for survival. In addition, consider that the interval $\mathrm{x} \in\left(\mathrm{x}_{1}: \mathrm{x}_{\mathrm{b}}\right)$ refers to basic needs goods such as clean water, agricultural goods, health services, and education. Let $\mathrm{x} \in\left(\mathrm{x}_{\mathrm{b}+1}: \mathrm{x}_{\mathrm{z}}\right)$ refer to leisure goods that raise utility above that of basic needs goods. A variety of studies have analyzed the effect that economic freedom has on basic needs belonging to the first interval. However, there has been no attempt to determine the effect of private property rights institutions on adoption of goods that improve quality of life beyond attainment of basic needs, for goods belonging to the second interval. For this reason the 
IHP may be a better measurement of well being in that it takes into account the attainment of technological goods.

\subsubsection{Measurements of Institutions}

Well-defined institutional rules must be accompanied by sound policy in order for there to be a positive effect on individuals. Political Risk Services (2004) publishes a group of measurements known as the International Country Risk Guide. Some of these variables are bureaucracy, corruption, democratic accountability, and rule of law. Norton (2003) uses the average of the first two to create a variable for quality of government, and the latter two to measure the "rule space." Countries with the highest government quality are Canada, Finland, and Denmark and the lowest quality of government occur in Somalia, Iraq, and the Democratic Republic of Congo. The most recent data provided by the Political Risk Services are slightly different than those obtained by Norton due to recent revisions. To create a variable measuring the Rule of Law, two other variables are averaged called Democratic Accountability and Law and Order. Among the countries with the highest rule of law measurement are Australia, Canada, Denmark and GuineaBissau; Somalia ${ }^{5}$ and Iraq have the lowest scores. These are unitized between zero and one.

As mentioned before the Economic Freedom of the World Index (EFW) will be used to measure the "policy space." The index estimates the degree of economic freedom for 128 countries. Hong Kong has the highest score in any particular year. However, Hong Kong will not be part of the sample of this study due to data limitations. In 2000, Hong Kong was followed by the United States and Singapore and the Democratic

\footnotetext{
${ }^{5}$ Somalia had no government during this period.
} 
Republic of Congo, Myanmar, and Zimbabwe were the least free. Luxembourg and Switzerland followed Hong Kong in 1985 whereas Nicaragua, Uganda, and Peru had the smallest measured economic freedom. Again, the index is derived using an equallyweighted average of five components. These components deal with government size, legal structure and property rights, money and inflation, freedom to trade internationally, and regulation. These are explained in detail in the Appendix.

The more each component would be expected to enhance productive activity, the higher the score. In other words, limited intervention by the government in private enterprise, sound definition and enforcement of property rights, low inflation and volatility of domestic currency, limited protectionism, and limited regulation yield high scores. The components range from zero to ten in the base year. The country with the highest rating receiving the value of ten. Each of the components consists of many subcomponents that will not be mentioned specifically. These subcomponents consist of actual data and surveys conducted for these countries. These variables have also been normalized between zero and one for the current analysis.

Most studies that have implemented these measurements have used the overall index value, but some authors have attempted to determine the effect of individual components on various left-hand-side variables (Ayal, 1998). This idea is intriguing, but must be approached with prudence. The different components are often highly correlated creating troubles with collinearity. The Appendix lists the correlation between the five components as well as the variables constructed from the International Country Risk Guide. Significant correlation is evident, and collinearity may be severe. The highest correlation exists between Property and Rule of Law (0.857) followed by 
Qualityofgovernment and Ruleoflaw (0.813), and Property and Qualityofgovernment (0.798). Also, Property and Trade are highly correlated (0.658). Regressions with these components may yield underestimated and insignificant $t$ statistics creating difficulty when analyzing the actual significance of each individual component. In this study the index will be used in its entirety in some regressions while in others it will be decomposed in order to analyze the specific effects of each on the quality of life.

The EFW data have been estimated at five-year intervals from 1970 to 2000 and yearly beginning in 2000 until 2002. Chain-linked data is available facilitating longitudinal studies. However, it is difficult to make strong inferences from such studies since the availability of periods is still lacking. Data is not available for all countries for the years used in this study. For this reason, unbalanced samples which include all of the countries with data available in any given year will be run in addition to balanced samples for the years $1985,1990,1995$, and 2000 . It is important to note that although the overall index has been chain-linked by its authors for comparisons through time, the individual components have not. To deal with this problem, using the scores for the individual components, the estimated economic freedom index score for each year, and the chain-linked economic freedom score for each year, chain-linked component scores are constructed for the purposes of this study. The Appendix provides an algebraic explanation of how these estimates are carried out.

\subsubsection{Other Variables in the Model}

Sachs and Warner (1997) contend that geographic and demographic measures are the main source of different levels of development. In particular, there are four variables that should be considered. First, countries that are subjected to tropical climates may 
experience a higher incidence of disease that might affect the ability and incentives required for more efficient production. For each country they estimate the proportion of each country that lies in a tropical climate region. This variable, Tropics, ranges from zero for a country that is located completely outside the tropical region to one for a country completely within such a region.

Next, Sachs and Warner point out that the inability of individuals to communicate can create significant costs in market exchange. They calculate the probability that any two individuals chosen randomly in a given country will speak a different language. This variable, Ethnic, was calculated in 1980. It is assumed that this has not changed significantly since that time and stays constant throughout the period of the sample. South Korea has the lowest probability equal to zero. Thus, there should be no expected impediments in carrying out transactions due to language barriers. Cameroon, on the other hand, has a value of 0.89 which would be hypothesized to cause problems in the market due to language differences. This variable is calculated differently than that which was used by Norton (2003), but the same in concept. The negative expected sign in the current paper is equivalent in interpretation to the positive sign expected in the aforementioned.

Another variable that should be considered is the amount of individuals that live in urban regions, considering the fact that poverty is more rampant in rural regions. Singapore has a value of one which should result in higher well being; whereas, Rwanda's value of 0.06 should result in lower than normal human development, ceteris paribus. This variable is named Urban. Finally, they account for all countries that are landlocked. Norton (2003) and others have used these measurements in their estimates. 
It has been demonstrated that such conditions cannot be ignored. The consequences of doing so could result in omitted variable bias and inconsistent results.

\subsection{Empirical Model}

Table 2.1 contains descriptive statistics for the data discussed so far. The basic theoretical model that will be tested in this study is akin to that used by Norton (2003) derived from Epstein's findings (1985). The main differences are that this study estimates panel data and a different dependent variable as a measurement for the quality of life.

The following benchmark equation will be estimated using Ordinary Least Squares adjusted for heteroskedasticity:

$$
\begin{aligned}
& \text { In }\left[\text { IHP }_{i t} /\left(1-I H P_{i t}\right)\right]=\beta_{0}+\beta_{1} \text { Landlocked }_{i}+\beta_{2} \text { Tropics }_{i}+\beta_{3} \text { Urban }_{i} \\
& +\beta_{4} \text { Ethnic }_{i}+\beta_{5} \text { Governmentquality }_{i t}+\beta_{6} \text { Ruleoflaw }_{i t}+\beta_{7} \text { Economicfreedom }_{i t} \\
& +u_{i t}, \quad \text { where } i=\text { countries }(1: 78) \text { and } t=\text { years }(1985,1990,1995 \text {, and } 2000)
\end{aligned}
$$

All the variables have been explained in some detail along with the rationale behind their inclusion. The purpose of (2.1) is to observe how the changes in economic freedom and other variables effect the change in the quality of life measurements. The log-odds of the IHP (Emes and Hahn, 2001) will be used as the dependent variable. Depending on the availability of the data, the sample sizes will differ for any given year. In order to maximize the total observations, unbalanced regressions will be analyzed in addition to balanced regressions. 
Table 2.1 Descriptive Statistics

\begin{tabular}{|l|ccccc|}
\hline \multicolumn{1}{|c}{ Variable } & Observations & Mean & Std. Dev. & Minimum & Maximum \\
\hline Log odds of IHP & 412 & -0.215 & 1.238 & -5.21 & 4.203 \\
Landlocked & 492 & 0.163 & 0.369 & 0 & 1 \\
Tropics & 372 & 0.502 & 0.473 & 0 & 1 \\
Urban & 512 & 0.509 & 0.236 & 0 & 1 \\
Ethnic & 465 & 0.4 & 0.289 & 0.17 & 0.93 \\
Qualityofgovernment & 468 & 0.532 & 0.245 & 0 & 1 \\
Ruleoflaw & 463 & 0.597 & 0.233 & 0.222 & 1 \\
Economicfreedom & 412 & 0.628 & 0.145 & -5.21 & 1 \\
Governmentsize & 492 & 0.539 & 0.162 & 0 & 1 \\
Property & 372 & 0.569 & 0.2 & 0 & 1 \\
Money & 512 & 0.538 & 0.204 & 0 & 1 \\
Trade & 465 & 0.614 & 0.168 & 0.17 & 1 \\
Regulation & 468 & 0.619 & 0.139 & 0 & 1 \\
\hline
\end{tabular}

The effect of individual components of Economic Freedom will be analyzed as well. The name of these five variables will be Governmentsize, Governmentsizesquared, Property, Money, Trade, and Regulation. Again, higher values for these indicators indicate higher contributions to economic freedom in a given country and would be expected to enhance well being. The expected sign of the institutional variables and Urban are positive ( $\beta_{5}, \beta_{6}, \beta_{7}$, and $\beta_{3}>0$ ); the expected sign for Landlocked, Tropics, and Ethnic is negative $\left(\beta_{1}, \beta_{2}\right.$, and $\left.\beta_{4}<0\right)$. Qualityofgovernment and Governmentsize are two distinct variables. The analysis will include unbalanced regressions to maximize the number of observations, but balanced regressions will be included as well.

Figure 2.1 displays a plot of the different components of economic freedom on the IHP. Four of these appear to have a positive relationship with the quality of life with Property and Regulation possibly providing a more convincing exhibition. Governmentsize appears to have neither a positive relationship nor a negative relationship. Nonetheless, Governmentsize will be included along with its squared value. 
Figure 2.1 Relationship Between Economic Freedom Components and the Index of Human Progress
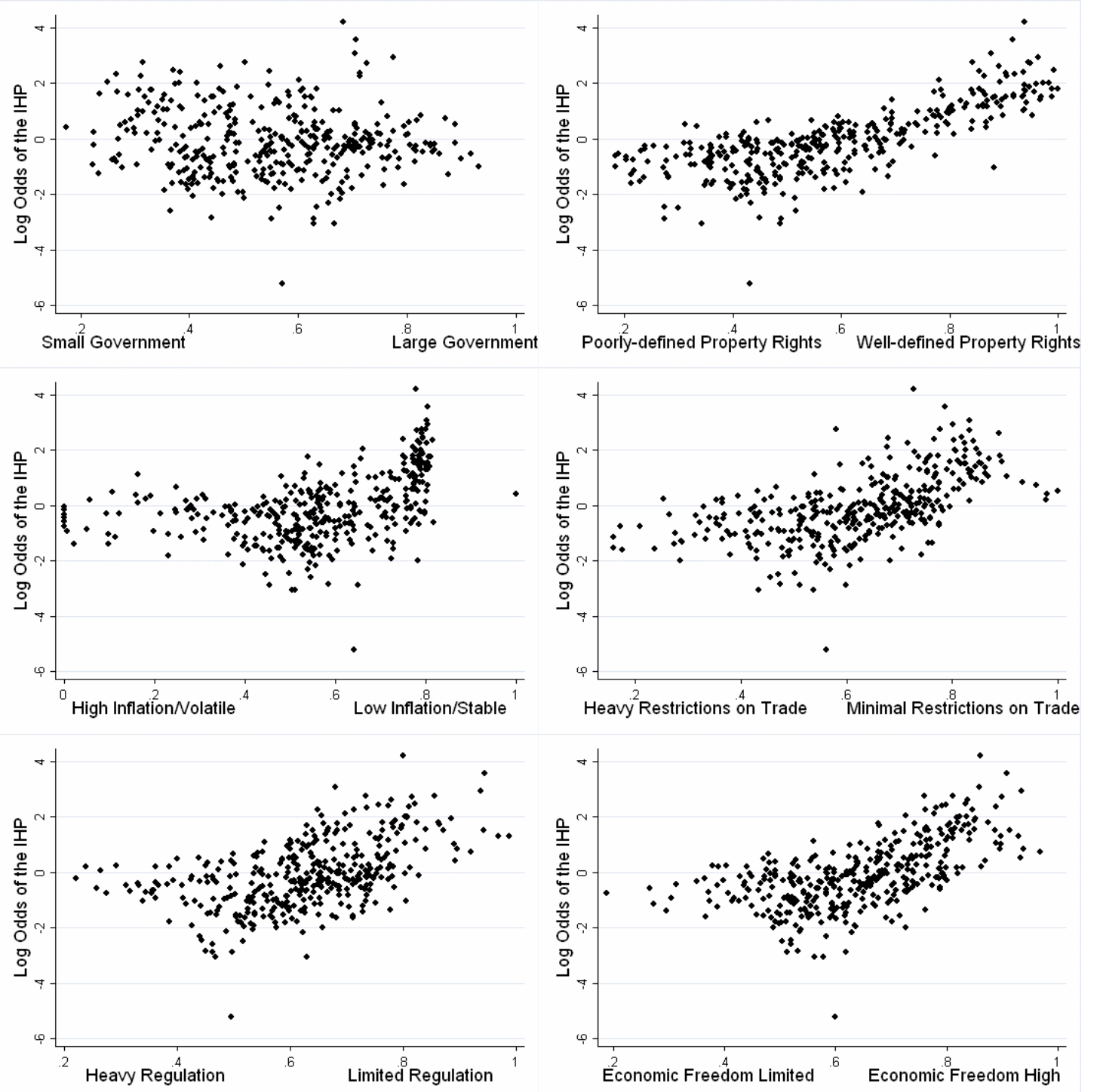

Scatter plots constructed using STATA version 6 on unbalanced panel-data sets from 1985, 1990, 1995, and 2000

The rationale behind including Governmentsizesquared is the theoretical possibility of a quadratic relationship between the size of government and quality of life. This has been done for various studies analyzing the impact of government size on income per capita and growth. The idea is that there is an initial improvement in wellbeing as the size of government increases in order to provide protection of property rights and create a legal 
system for good institutions to flourish. However, there is likely a point at which the government's size will result in less production in the economy due to crowding out of productive activities and other reductions in incentives. The expected signs for Governmentsize and Governmentsizesquared are positive and negative respectively.

\subsection{Empirical Results}

Table 2.2 displays the results for estimations of (2.1) for both the balanced and unbalanced samples. All regressions are corrected for heteroskedasticity. Landlocked is not significant in either of these regressions. The remaining variables are significant and as expected. All the institutional variables are significant and positive. The negative sign on Ethnic and Tropics demonstrates that language barriers as well as the geographic location in the tropics can have a significant impact on wellbeing. Urban's positive sign is consistent with the idea that countries with more urbanized populations enjoy greater welfare possibly due to economies of scale or migration to the cities as a result of improvements in agricultural technology.

If the coefficients are any indicator of the relative importance of these variables, then Urban has the greatest impact $(1.593,1.652)$ followed by Qualityofgovernment $(1.557,1.262)$ and Economic Freedom $(1.298,1.369)$. Ruleoflaw $(0.516,0.712)$ is positive, but it is significant in only one of the regressions. Tropics $(-0.374,-0.485)$ and Ethnic $(-0.398,-0.375)$ have the smallest impact of the significant variables. Recall that all of the variables are normalized between zero and one in order to make the estimates more comparable. 
Table 2.2 Regression Results with IHP as the Dependent Variable

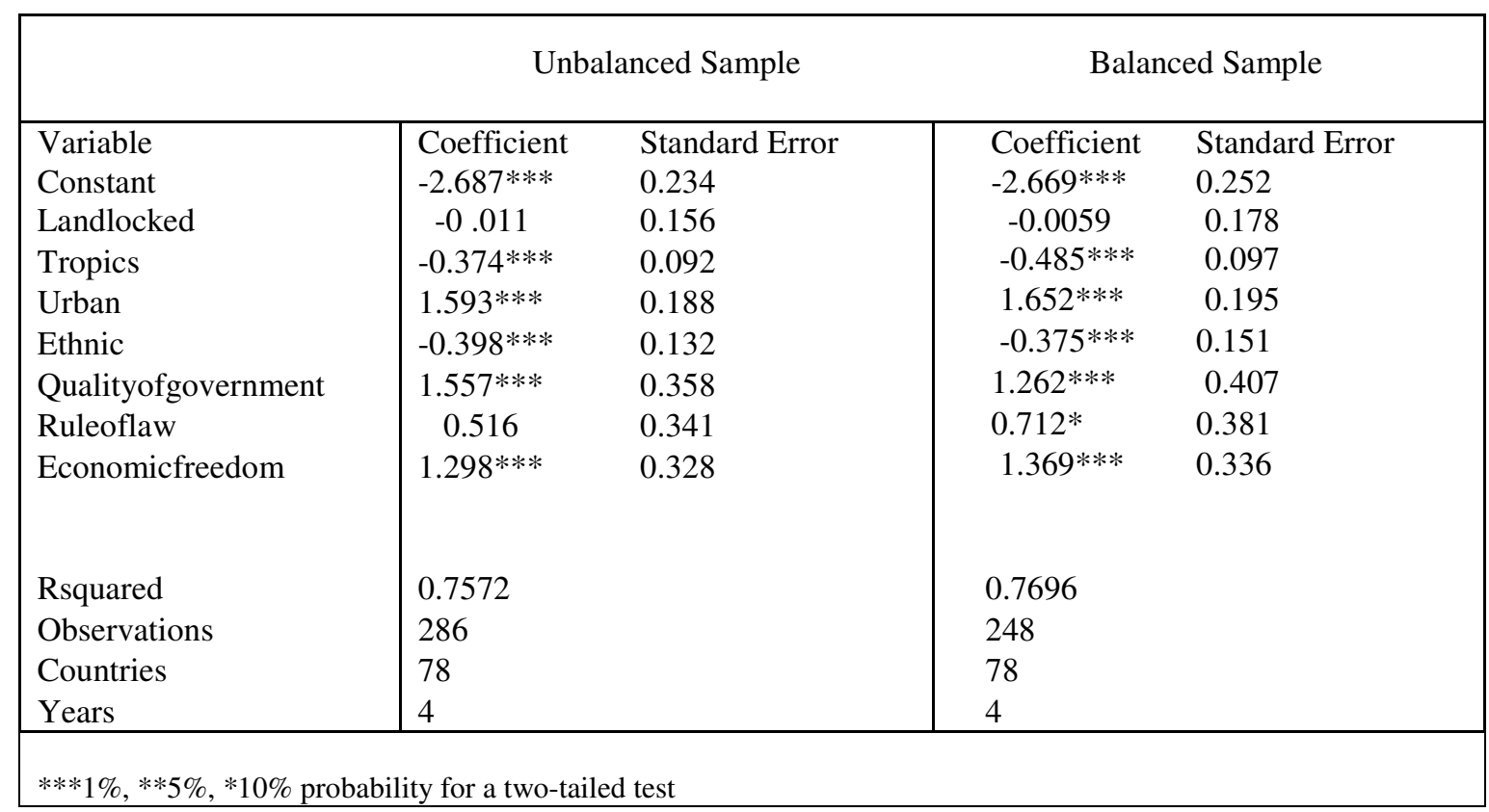

Table 2.3 displays the balanced and unbalanced results for the regressions for (2.1) with economic freedom decomposed into its five main components. The geographic variables yield similar results. Ruleoflaw is again significant in one regression $(0.421,0.733)$. Qualityofgovernment is insignificant in both regressions, but it is still positive. Governmentsize, Governmentsizesquared, Property, and Regulation are significant. Money and Trade are insignificant. Regulation appears to have the largest impact of all these $(1.745,1.843)$ followed by Property $(0.95,1.184)$. Governmentsize $(-4.745,-6.074)$ and Governmentsizesquared $(4.334,5.774)$ yield a peculiar outcome. Both are significant, but the signs are not consistent with the expected outcome. This would indicate a U-shaped relationship between the size of government and the quality of life as opposed to the inverted $U$ shape. This suggests that as the size of government increases from no government, the quality of life would reduce. As the size of government continues to increase, there is a threshold size at which the quality of life 
Table 2.3 Regression Results with IHP as the Dependent Variable and the Economic Freedom Decomposed

\begin{tabular}{|c|c|c|c|c|}
\hline \multirow[b]{2}{*}{ Variable } & \multicolumn{2}{|c|}{ Unbalanced Sample } & \multicolumn{2}{|c|}{ Balanced Sample } \\
\hline & Coefficient & Standard Error & Coefficient & Standard Error \\
\hline Constant & $-1.536 * * *$ & 0.159 & $-1.197 * * *$ & 0.442 \\
\hline Landlocked & -0.0129 & 0.114 & -0.011 & 0.206 \\
\hline Tropics & $-0.424 * * *$ & 0.187 & $-.5156^{* * *}$ & 0.126 \\
\hline Urban & $1.489 * * *$ & 0.132 & $1.488 * * *$ & 0.199 \\
\hline Ethnic & $-0.3688 * * *$ & 0.385 & $-0.371 * * *$ & 0.137 \\
\hline Qualityofgovernment & $1.287 * * *$ & 0.357 & $1.144 * *$ & 0.455 \\
\hline Ruleoflaw & 0.421 & 1.33 & $0.733^{*}$ & 0.383 \\
\hline Governmentsize & $-4.745 * * *$ & 1.225 & $-6.074 * * *$ & 1.438 \\
\hline Governmentsizesquared & $4.334 * * *$ & 0.405 & $5.774 * * *$ & 1.347 \\
\hline Property & $0.950 * * *$ & 0.259 & $1.184 * * *$ & 0.43 \\
\hline Money & -0.142 & 0.4 & -0.252 & 0.318 \\
\hline Trade & -0.6578 & 0.537 & $-1.145^{* *}$ & 0.465 \\
\hline Regulation & $1.745 * * *$ & 0.159 & $1.843 * * *$ & 0.605 \\
\hline Rsquared & 0.7795 & & 0.7975 & \\
\hline Observations & 280 & & 232 & \\
\hline Countries & 62 & & 58 & \\
\hline
\end{tabular}

would begin to increase as the size of government increases beyond this point. Carlsson and Lundstrom (2002) obtain a similar finding with regards to the effect of the size of government component on economic growth. In other words, both small and large government be optimal in improving quality of life. Such a finding does not make much sense in theory although the plot in Figure 2.1 could demonstrate many different types of relationships depending one how one looks at it.

To further analyze this problem, one more set of regressions is analyzed to better understand the impact of the size of government on the quality of life. The EFW component measurement for the size of government (Governmentsize) is an average of government consumption as a percentage of GDP, government owned enterprises as a percentage of total ownership, transfers and subsidies as a percentage of GDP, and government investment as a percentage, and the top marginal tax rate and the threshold at 
which it applies in a given country (Gwartney and Lawson, 2005). Instead of using the estimated component from the EFW, a simpler measurement is used. Total government expenditures as a percentage of GDP from the Penn World Tables is considered. This variable will be called Governmentexpenditures and Governmentexpendituressquared to avoid confusion with the EFW variable, but it seeks to measure the same thing. Figure 2.2 demonstrates the relationship between this indicator and the IHP in a scatter plot diagram.

Table 2.4 displays the regressions using this indicator. This table includes four regressions. The first two and the upper portion include both the non-squared and squared variable in the first columns and a regression with just the non-squared value for an unbalanced panel-data set. The reason for this is that the plot in Figure 2.2 seems to indicate a possible negative relationship. In the first regression, the coefficients again yield the unexpected signs. However, in this regression, only Governmentexpenditures is significant. In the regression without the squared term, Governmentexpenditures is negative and significant. The remaining policy and institution variables yield similar results to the previous tables with the exception of Qualityofgovernment which is insignificant in both regressions. The geographic variables yield the same outcomes as well in significance and magnitudes. The lower-portion includes the same two regressions using a balanced panel-data set. The regression with both the squared and non-squared values results in the same unexpected signs as in the previous regressions and both of these coefficients are significant. The negative coefficient in the balanced panel regression without the squared value is significant. It should be noted that this is 
Figure 2.2 Relationship Between Economic Freedom Components and Index of Human Progress

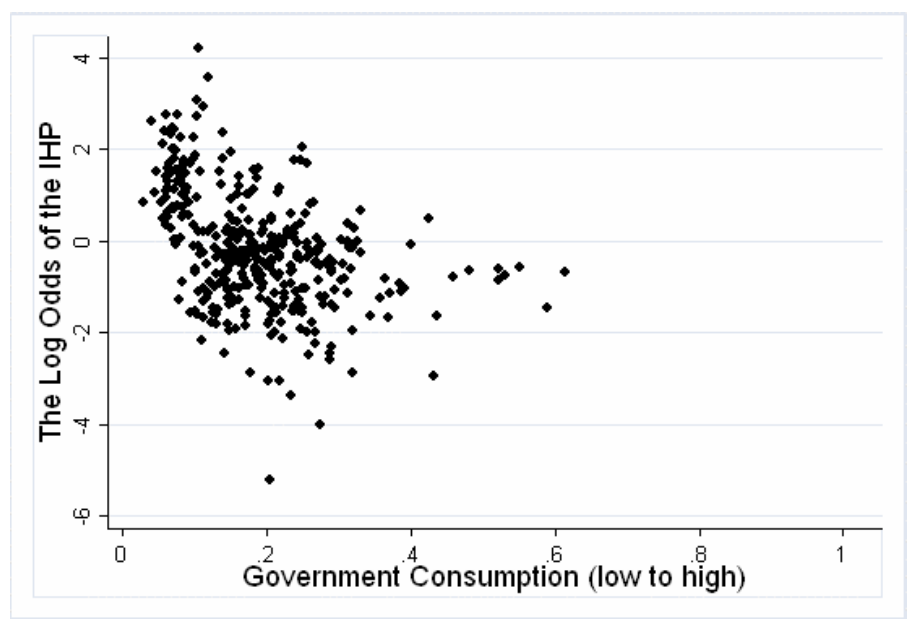

the same as indicating that a high value of the EFW component Governmentsize would be associated with higher IHP since a higher value of Governmentsize implies lower government expenditures as a share of GDP. The negative sign on the non-squared term would therefore be expected if the relationship is not quadratic. The remaining results are consistent with the other regressions with the exception of the fact Property is not quite significant at conventional levels. Landlocked, Money, and Trade are not significant in any of the regressions in which they are included.

Regulation and Qualityofgovernment are robust in that they are significant in all of the regressions in which they are included. Property is significant in four out of the six and Ruleoflaw is significant in five out of eight. Tropics, Ethnic, and Urban are robust as well. 
Table 2.4: Regression Results with IHP as the Dependent Variable and the Economic Freedom Decomposed and Government Expenditure from Penn World Tables






\subsection{Conclusion}

Although many studies have used the Economic Freedom of the World index (Gwartney and Lawson, 2005) to analyze its effect on measurements of well being, few have looked at the effect of the five subcomponents of this index on the quality of life. This study has demonstrated that trade policy, property rights institutions, and limited regulation are positively associated with quality of life as measured by the Index of Human Progress (IHP). The marginal benefit to increasing government involvement in the development of nations in the form of higher expenditures and tax rates is ambiguous. However, the benefits from establishing sound property rights and maintaining a legal system that protects these rights has a far greater impact than government subsidies and transfers and other policies. The same can be said with regards to low regulation in the market.

This paper provides further empirical evidence of the ideas suggested by North (1990, 1991), De Soto (2000), and Epstein (1985) that the establishment of well-defined property rights increases efficiency in the market, provides incentives for individuals to be productive. Policymakers seeking to alleviate poverty and improve the quality of life for their constituents would best achieve this objective by developing institutions of welldefined property rights and a legal system that protects these rights. Limited regulation also appears to be effective in this regard. However, this study merely contributes to the many studies that indicate that quality institutions are associated with better economic outcomes. The development of institutions and the internal acceptance of these by the developing world is a more difficult issue to be resolved. 


\section{CHAPTER 3}

\section{ECONOMIC FREEDOM AND MIGRATION FLOWS BETWEEN U.S. STATES}

"If government is to exercise power, better in the county than in the state, better in the state than in Washington. If I

do not like what my local community does... I can move to another local community, and though few may take this step, the mere possibility acts as a check. If I do not like what Washington imposes, I have few alternatives in this world of jealous nations."

—Milton Friedman, 1962 


\section{CHAPTER 3}

\section{ECONOMIC FREEDOM AND MIGRATION FLOWS BETWEEN U.S. STATES ${ }^{6}$}

\subsection{Introduction}

Tiebout (1956) provided the foundation for analyzing the effects of local government policy differentials on migration. As long as consumers are fully mobile and informed, restrictions to employment opportunities are low, and public services provide no externalities or diseconomies between communities, consumers convey their preferences through migration or "voting with their feet." Hayek (1945) addressed the idea that local governments are more capable of making better decisions than federal officials due to a greater access to knowledge concerning the needs of their localities.

Weingast (1995) contends that these two arguments do not completely describe the benefits of federalism where federalism is defined as a separation of power between different levels of government. In addition to creating jurisdictional competition as suggested by Tiebout, federalism can create incentives for political officials to promote markets which enhance total utility (Qian and Weingast, 1997). When there is sufficient separation of authority in economic matters between the federal and local governments, this is known as market-preserving federalism. If a country meets the standards as a market-preserving federation, migration is likely to result in more efficient policies that result in higher wellbeing of individuals in the long run.

As there is no natural tendency for firm leadership to respond to the demands of shareholders (Coase, 1937), there is no reason to assert that political officials efficiently

\footnotetext{
${ }^{6}$ This chapter is based on Ashby (2007)
} 
respond to the welfare needs of constituents. Effective government institutions align the incentives of officials to the will of the citizens similar to the manner in which institutions of firms can induce an effective response to the wellbeing of shareholders. Federalism is one such institution. If individuals are free to migrate between jurisdictions, this serves as a check on government intrusion in economic matters. In a market-preserving federation, states face a hard budget constraint in that they have no ability to print currency and little ability to borrow or rely on higher levels of government. If local governments maintain autonomous power in economic matters separate from the higher jurisdiction, they have little incentive to bail out inefficient economic projects or seize wealth from efficient industries. This forces local government to weigh the benefits versus the costs of such actions since they might drive economically significant labor and capital to neighboring localities. When local governments systematically receive economic assistance from higher levels of government, this violates the principle of market-preserving federalism endangering the sustainability of markets and opportunities for efficient utility maximization through migration.

The study of federalism entails important policy implications for enhancing the welfare of individuals and obtaining more efficient economic outcomes. Weingast (1995) demonstrates that the relative federalistic nature of China's government compared to Russia has led to economic benefits which have far exceeded its former counterpart in communism. This being the case, Holcombe (1994) suggests that constitutional rules limiting authority at the national level are more important than at the local level due to the relative immobility of individuals. It is conjectured that any policies that limit the authority of the national government on economic matters will result in sustaining 
market-preservation and create incentives for political officials to align themselves with the welfare of their constituencies. The question to be addressed in this paper is whether or not individuals in aggregate react in this manner suggested by Weingast and others. In other words, this analysis seeks to determine whether individuals in aggregate migrate toward states with higher economic freedom and estimate the marginal impact of policies that contribute to economic freedom. Economic freedom impacts the opportunities for employment and income. In addition to these indirect benefits, it could be that individuals receive enhanced utility from economic freedom.

This paper will be divided into four parts. Section 2 will provide further discussion of economic freedom and market-preserving federalism and a brief review of migration theory. Section 3 explains the contribution of this analysis to prior literature and the model that will be tested in this study. In particular, this paper will analyze the effects of economic freedom on the migration behavior of the working population in the lower 48 U.S. states. The Economic Freedom of North America Index (Karabegovic and McMahon, 2005) will be decomposed into its major components to analyze the impact that these measures have on migration flows between states. Spatial methods will be used in this analysis as well. Spatial models take into account spatial dependence and heterogeneity between observations that are not detected by the standard distance variables included in gravity models. Porojan (2001) utilizes spatial methods to analyze trade flows between the European Union and potential members using a modified gravity model. Other than the above mentioned study, spatial econometrics has been greatly underutilized in migration research (Cushing and Poot, 2004). Section 4 will analyze the 
empirical results and give a detailed interpretation. Section 5 will conclude the paper with summary remarks and a discussion of policy implications.

\subsection{A Review of the Literature}

\subsubsection{Economic Freedom and Market-Preserving Fiscal Federalism}

Friedman (1962) postulates that economic freedom is important for two reasons. First, it is an end in itself. Second, it is a "necessary but not sufficient" condition towards obtaining and maintaining political freedom. Economic freedom may include measurements of freedom from coercive property and income taxation, the extent of government control over the private sector, and the liberty to work at the occupation and remuneration of one's choosing and buy or sell goods at prices determined independent of the government. In addition to these reasons, market institutions induce political officials to react to the preferences of the private citizens (Weingast, 1995; Qian and Weingast, 1997).

Riker (1964) provides two qualifications for a government to be considered a federation. First, there must be a hierarchy of governments with at least two levels with a demarcated scope of authority. Second, the autonomy of each level must be institutionalized in a manner that makes the restrictions of federalism self-enforcing. Weingast (1995) further defines a market-preserving federation as one in which the subnational government possesses primary regulatory authority in economic matters, has no trade barriers, and faces a hard budget constraint. According to this definition, Weingast postulates that the United States acted under this type of system during the nineteenth century until the 1930s. Although the contemporary United States does not 
qualify according to Weingast's definition, it is one of the more federalistic nations. The more economic authority is decentralized, the more efficient the economic outcome will be through migration.

The indexes of economic freedom are often used to measure the extent to which economic systems rely on free markets. Numerous studies evaluate the relationship between economic freedom and measurements of well-being such as income, life expectancy, and/or education at the international and national level. However, one could also assert that the propensity to migrate is also a function of individuals seeking to maximize utility through revealed preference. This paper analyzes the impact of government policy that enhances economic freedom on gross migration flows in the lower 48 U.S. states.

Several studies have been conducted analyzing the effect of economic freedom on measurements of well-being such as income, poverty, and human development measurements. Many of these have been cross-national analyses using either the Economic Freedom of the World Index published by Gwartney and Lawson (2005) through the Fraser Institute or that by Miles, et al. (2006) of the Heritage Foundation. Most find a significant positive relationship between these measures and quality of life. A positive link of economic freedom has been made with higher incomes per capita and economic growth (Ali, 1997; Ayal and Karras, 1998; De Haan and Sierman, 1998; Easton and Walker, 1997; Islam, 1996). Farr, Lord, and Wolfenbarger (1998) and Gwartney, Lawson, and Holcombe (1999) demonstrate that causality runs in the direction from economic freedom to economic growth and not vice versa. Since there is some disagreement as to the use of income or income growth as legitimate measurements of 
well-being, numerous studies exist that have demonstrated that economic freedom is associated with higher human development, lower poverty, higher literacy rates, and other positive aspects of quality of life (Esposto and Zaleski, 1999; Grubel, 1998; Norton, 1998). In addition, Adkins, Moomaw, and Savvides (2002) using panel data demonstrate that institutions that promote economic freedom lead to higher technical efficiency. Hanson's (2003) recent criticism of the findings of studies demonstrating the positive effects of economic freedom and institutions has received some attention. Such criticisms include alleged endogeneity between economic freedom and other variables such as GDP per capita and the incompatibility of various measurements of economic freedom. However, Heckelman (2005) argues that the criticisms provided by Hanson are not made on a thorough analysis of the literature, and that there are flaws to the analysis. In fact, most of Hanson focuses most of his criticism on just one study (Hanke and Walters, 1997).

Recently, similar data have been constructed that measure economic freedom in U.S. states as well as Canadian provinces by Karabegovic and McMahon (2005) of the Fraser Institute. $^{7}$ Using these data the authors demonstrate that higher average scores of economic freedom are significantly associated with higher average incomes and income growth rates in the North American Region. The data are provided at both a national and subnational level. The national data measure the extent to which economic freedom is restricted at all levels of government; the subnational index measures the extent of

\footnotetext{
${ }^{7}$ The Pacific Research Institute has also constructed an index called the U.S. Economic Freedom Index (McQuillan, 2004). The weights used to construct the overall index are actually taken from a regression analysis using each state's own rate of net migration. For this reason, this measurement is of little use to analyze migration as it is already incorporated into the index itself. In addition, this analysis only observes each state's net migration and does not take into account the origin or destination state. Thus, it is impossible to determine whether the individuals are moving into high freedom states from other high freedom states or low freedom states.
} 
Table 3.1 Components of Economic Freedom of North America Index

Area 1: Size of Government
1A: General consumption expenditures by government as a percentage of GSP
1B: Transfers and subsidies as a percentage of GSP
1C: Social Security Payments: Employment insurance, workers compensation, and other
pensions as a percentage of GSP
Area 2: Takings and Discriminatory Taxation
2A: Total Tax Burden as a Percentage of GSP: Includes income taxes, consumption
taxes, property and sales taxes, contributions to Social Security plans, and other taxes
2B: Top marginal income tax rate and the income threshold at which it applies
2C: Indirect tax revenue as a percentage of GSP: Includes property taxes, contributions to
Social Security Insurance, and various other taxes
2D: Sales taxes collected as a percentage of GSP: Includes general sales tax revenues as
well as revenue from liquor and tobacco taxes
Area 3: Labor Market Freedom
3A: Minimum wage legislation: Annual income earned by an minimum-wage worker
divided by per-capita GSP
3B: Government Employment as a percentage of total state/provincial employment
3C: Union density
Source: Karabegovic and McMahon (2005)

restriction at the state or provincial and local level. Table 3.1 displays the ten components used to calculate this index at the national level. These components are used to make economic freedom scores for each state from 1981 to 2002. This index consists of three major components: Size of Government, Takings and Discriminatory Taxation, and Labor Market Freedom. The larger the size of the government, the lower the freedom of individuals to benefit from private enterprise; the greater the tax burden, the lower the individual freedom to consume or invest; and the more restrictive the labor market, the more difficult it is for employers and workers to negotiate mutually beneficial outcomes. A more specific list of these components is included in Table B.1 in the 
Table 3.2 Economic Freedom Rank (1990-95 Average)

\begin{tabular}{|c|c|c|c|c|c|}
\hline Rank & State & Score & Rank & State & Score \\
\hline 1 & Delaware & 7.97 & 24 & Kansas & 6.62 \\
\hline 2 & Texas & 7.45 & 26 & Vermont & 6.60 \\
\hline 3 & North Carolina & 7.40 & 27 & Minnesota & 6.57 \\
\hline 4 & Georgia & 7.28 & 27 & Wisconsin & 6.57 \\
\hline 5 & New Hampshire & 7.17 & 29 & Arizona & 6.53 \\
\hline 6 & Connecticut & 7.10 & 30 & Arkansas & 6.52 \\
\hline 6 & Tennessee & 7.10 & 31 & Ohio & 6.50 \\
\hline 8 & Illinois & 7.07 & 31 & Pennsylvania & 6.50 \\
\hline 8 & Nevada & 7.07 & 33 & Florida & 6.47 \\
\hline 8 & Wyoming & 7.07 & 34 & Alabama & 6.45 \\
\hline 11 & Louisiana & 7.05 & 35 & Idaho & 6.43 \\
\hline 12 & Indiana & 7.02 & 36 & Michigan & 6.40 \\
\hline 13 & Nebraska & 6.98 & 36 & Oklahoma & 6.40 \\
\hline 14 & Colorado & 6.95 & 38 & Maryland & 6.37 \\
\hline 14 & Massachusetts & 6.95 & 39 & New York & 6.32 \\
\hline 16 & Virginia & 6.92 & 40 & Washington & 6.23 \\
\hline 17 & Missouri & 6.90 & 41 & Oregon & 6.22 \\
\hline 18 & South Carolina & 6.82 & 42 & Mississippi & 6.13 \\
\hline 18 & Utah & 6.82 & 43 & New Mexico & 6.10 \\
\hline 20 & South Dakota & 6.78 & 44 & Rhode Island & 5.92 \\
\hline 21 & California & 6.73 & 45 & North Dakota & 5.90 \\
\hline 21 & Kentucky & 6.73 & 46 & Maine & 5.85 \\
\hline 23 & New Jersey & 6.65 & 47 & West Virginia & 5.43 \\
\hline 24 & Iowa & 6.62 & 48 & Montana & 5.37 \\
\hline
\end{tabular}

Source: Karabegovic and McMahon (2005)

Appendix. Note that $2 \mathrm{~A}$ contains elements from $2 \mathrm{C}$ and $2 \mathrm{D}$. For this reason, this analysis will not include $2 \mathrm{C}$ and $2 \mathrm{D}$ when analyzing the separate components. $2 \mathrm{~A}$, which measures the total tax burden, will be sufficient. This will be discussed below in the discussion of the variables to be analyzed.

Table 3.2 displays the rankings of states by economic freedom score. The averages are taken from 1990 to 1995 since this is the period that will be used in the analysis. Delaware had the highest level of economic freedom during the period followed by Texas, North Carolina, Georgia, and New Hampshire. Montana experienced 
the lowest level of economic freedom followed by West Virginia, Maine, North Dakota, and Rhode Island. Interestingly, it seems that no study has been carried out to analyze the effect that economic freedom has on gross migration or the migration decision of individuals at the state level. At the international level, Melkumian (2004) finds that lower economic freedom in non-U.S. countries is a significant determinant of migration to the United States.

\subsubsection{Migration}

Gravity models are often utilized in regional economics to analyze the effects that distance and population size of localities have on migratory forces (Borjas, 1989; Greenwood, 1975). Such models were derived from the equation for gravitational force used in the physical sciences. An unconstrained gravity equation would be

$$
M_{i j}=\frac{G P_{i}^{\beta_{1}} P_{j}^{\beta_{2}}}{D_{i j}^{\alpha}}
$$

(Greenwood, 1997) where Mij denotes gross migration from location i to location j, G is a constant, $P_{i}$ and $P_{j}$ represent the population in locations $i$ and $j$, and $D_{i j}$ is the distance between these two locations. By taking logs on both sides and including other control variables a reduced-form model can be derived to analyze migratory behavior empirically:

$$
m_{i j}=\alpha_{0}+\alpha_{1} p_{i}+\alpha_{2} p_{j}+\alpha_{3} y_{i}+\alpha_{4} y_{j}+\alpha_{5} d_{i j}+z(.)+\varepsilon_{i j}
$$


Note that the lower case variables in (3.2) represent the log form of the coinciding upper case variables in (3.1). $y_{i}$ and $y_{j}$ represent income for both locations and $d_{i j}$ denotes the travel costs between the localities. Since this is difficult to measure, the shortest flying distance is often used as a proxy variable (Borjas, 1987). The variable $z($.$) includes the$ attributes of the origin and destination localities, and $\varepsilon_{\mathrm{ij}}$ serves as the conventional error term. Some of these attributes may include economic conditions (Borjas, 1989) or measurements of political and/or civil freedoms (Gastil, 1987). All variables are in log terms, although sometimes in empirical work logs or a combination of logs and levels are used.

Greenwood (1997) provides a survey of literature pertaining to internal migration in developed nations. It is believed that the United States and Canada have higher propensities to migrate than other developed nations. Two major trends have been observed in the United States. First, the South has had the greatest net migration (inmigrants minus outmigrants) in recent years. Second, populations in metropolitan areas are increasing more slowly than in non-metropolitan areas.

The data for migration are obtained from the U.S. Census of Population and Housing (2000). The survey is available every ten years. These data provide a state-tostate estimate of the total number of individuals that moved in the final five years of the given decade (i.e., 1995 to 2000, etc.). The destination state, as well as the state of origin, is provided. This means that for each of the 48 lower states there are gross migration estimates for 48 possible destinations including the possibility for individuals 
to remain in the state of origin. ${ }^{8}$ Migration from individuals inside the United States to outside of the country is not considered as well as all inward migration from foreign countries. Migration that occurs within each state is also not counted. This amounts to 2,304 observations for the 2000 survey. ${ }^{9}$ There has been debate in the migration literature about whether to use gross or net migration. However, by design the gravity model measures gross outmigration from origin to destination (Greenwood et al., 1991). Rather than using the total state-to-state migration flows as a dependent variable, migration flows for the population as a percentage of the population at risk is often used. The population at risk is defined as the population at the beginning of the migration period. Typically, the total number of outmigrants in any given state is added to the population over five years old in 2000, and the number of inmigrants is subtracted from the population over five years old in 2000. The log-odds of working-age migrants from an origin state to the destination state as a percent of the working-age population at risk in the origin state will be used in this study. This will be explained below.

The manner of analyzing migration behavior is in terms of utility maximization. All else equal, individuals will move to a new location if the perceived utility from doing so is greater than the utility of not moving. In a sense, migration is a better measurement of utility improvements than other measurements of well-being because preferences are manifested through revealed actions. Douglas (1997) postulates that there is a consensus about certain attributes that improve utility and desirability of some locations compared

\footnotetext{
${ }^{8}$ The Economic Freedom of North America Index does not provide a score for the District of Columbia.

${ }^{9}$ There were no migrants from Rhode Island to North Dakota and vice versa between 1995 and 2000 as estimated by the U.S. Census survey. Unfortunately, since the log of these numbers will need to be taken for the analysis, values of zero would create problems. To deal with this problem, the minimum positive value was assigned to these observations.
} 
to others. There may be certain idiosyncratic characteristics that either increase or diminish a location's attractiveness such as closeness to family. Aggregate migration patterns between locations are assumed on average to reflect the consensus as to relative standard of living in those locations. However, on average the idiosyncratic deviations from the consensus cancel themselves out. Greenwood et al. (1991) and Douglas and Wall (1993) also approach migration in this manner.

Various studies have analyzed the impact of public policy on migration. Charney (1993) provides a survey of such studies. Other studies include Cebula (1990), Clark and Hunter (1992), and Saltz (1998).

\subsection{The Model}

The contribution of this study is to analyze the effect that the policies that contribute to economic freedom have on migration flows between states. It is expected that individuals migrate from states with lower economic freedom to states with higher economic freedom after controlling for various other factors of migration. In order to obtain consistent results, it is important to consider the possibility of spatial relationships between observations (Lesage, 1998). It could be argued that the distance variable in the gravity model will account for the spatial effects. This might very well be the case. However, it is possible that there are other spatial effects that are not fully captured by the distance variables. Therefore, it is necessary to test for spatial effects to determine whether or not a spatial estimator should be used. A general statistical model of spatial dependency is demonstrated in (3) below: 


$$
\begin{aligned}
& y=\rho W_{1} y+x \beta+u \\
& u=\lambda W_{2} u+\varepsilon \\
& \mathcal{E} \sim N\left(0, \sigma^{2} I_{n}\right)
\end{aligned}
$$

$y$ is a column vector of the dependent variable being analyzed. $W_{l}$ and $W_{2}$ are square weight matrices or contiguity matrices that measure proximity to a given observation. The matrix labeled $x$ contains the explanatory variables, $\beta$ is a matrix for the measured coefficients, $u$ is the error term, and $\mathcal{E}$ is the error term of $u$ with a standard normal distribution and a mean of zero. Specifically, the model that will be estimated in this study is as follows:

$$
\operatorname{Ln}\left[\frac{\text { (Migrationrate } \left._{i j}\right)}{1-\left(\text { Migrationrate }_{i j}\right)}\right]=\alpha_{0} \text { Stay }_{i j}+\beta_{0} \text { Constant } \rho W \operatorname{Ln}\left[\frac{\text { (Migrationrate } \left._{i j}\right)}{\left.1-\text { (Migrationrate }_{i j}\right)}\right]
$$

$+\beta_{1}$ EconomicFreedom $_{j} /$ Economicfreedom $_{i}+\beta_{2}$ Ln Population $_{j} /$ Population $_{i}$

$+\beta_{3}$ Ln Density $_{j} /$ Density $_{i}+\beta_{4}$ Ln Income $_{j} /$ Income $_{i}$

$+\beta_{5}\left[\right.$ Employmentgrowth $_{j}-$ Employmentgrowth $\left._{i}\right]+\beta_{6}$ Retired $_{j} /$ Retired $_{i}$

$+\beta_{7}$ Heatingdays $_{j} /$ Heatingdays $_{i}+\beta_{8}$ Precipitation $_{j} /$ Precipitation $_{i}$

$+\delta_{1}$ Distance $_{i j}+\delta_{2}$ Distancesquared $_{i j}+\lambda W u+\varepsilon_{i j}$

The subscript $\mathrm{i}$ is used to indicate the origin state and $\mathrm{j}$ is used for the destination state. The contiguity matrices $(W)$ in Equation 3.4 are row standardized. In other words, the sum of the values given to each contiguous state for a given state is equal to one. Since Alabama has four contiguous states, a value of 0.25 will be given to Florida, Georgia, Mississippi, and Tennessee. This is a more intuitive method of measuring the impact of 
adjacency than including a dummy variable for each possible contiguous relationship for a given geographical region. Some states obviously have fewer contiguous relationships than others. It is possible for both weight matrices $\left(W_{l}\right.$ and $\left.W_{2}\right)$ to be the same, although this is not necessary. In this study they are constrained to be equal $\left(W_{1}=W_{2}=W\right)$.

Applying spatial econometrics to a gravity model with multiple origins requires some adjustments due to the nature of the problem being analyzed. Typically, a gravity model considers all the possible destinations of migration for each observation excluding all cases in which the origin is also the destination. In the case of this study, since 48 states are being analyzed, this would mean that there would normally be 47 possible destinations for all 48 states resulting in a total of 2,256 observations. However, this produces a problem in constructing the weight matrices since the matrix must be square. Each individual row will represent the contiguous relationship of a destination state. If this particular destination state has a contiguous relationship with the origin state, this will positively impact migration to this state $(\rho>0)$.

There must be an observation included for cases in which $\mathrm{i}=\mathrm{j}$ (origin=destination). The question arises as to what should be included in this situation. Such observations are only included in order to perform spatial estimation. The purpose of the gravity model is to analyze the determinants of migration flows. For these observations, the total working-age population in 1995 will be used. ${ }^{10}$ Since there are 48 states in the analysis, there are obviously 48 "stayers." The remaining 2,256 observations will be known as "movers." Stay ${ }_{i j}$ is a dummy variable equal to one for all "stayers" observations where $\mathrm{i}=\mathrm{j}$ and zero otherwise. By including this dummy, it is possible to separate the effects for

\footnotetext{
${ }^{10}$ The data is divided into 17 age groups. This study includes individuals age 20 to 59 in 1995 . These groups are $05,06,07,08,09,10,11$, and 12 according to the U.S. Census age classifications.
} 
the non-mover while still enabling construction of a square weight matrix. ${ }^{11}$ This results in 2,304 observations and a 2,304 by 2,304 square weight matrix characterized by an identical contiguity matrix located on each diagonal block with all positions above and below the diagonal blocks filled with zeros. The contiguity matrix for the first 48 observations (Alabama and its 48 possible destinations including the possibility of staying in Alabama) will be located in the upper-diagonal block of the matrix where each row measures the contiguous relationship of each possible destination state for individuals living in Alabama in 1995. Likewise, the lower diagonal block will contain the contiguity matrix for all 48 of the potential destinations from Wyoming.

The coefficient labeled $\rho$ (rho) in Equations 3 and 4 measures the effect that neighboring observations have on the dependent variable and $\lambda$ (lambda) measures correlation in the error term. If $\rho$ and/or $\lambda$ are different from zero, then spatial dependence exists (Lesage, 1998). There are three estimators in particular which can be used. If $\rho \neq 0$ and $\lambda=0$, then the model is reduced to a spatial autoregressive model (SAR) with a normally distributed error term. In this case the coefficient estimates of ordinary least squares (OLS) are biased and inconsistent. If $\rho=0$ and $\lambda \neq 0$, then there is correlation in the error term known as a spatial error model (SEM). The estimated OLS coefficients are consistent, but inefficient. Finally, if both coefficients are different than zero, then the model is a general spatial model (GSAR). In this case the OLS estimates are also biased and inconsistent. Surprisingly, spatial issues have not been

\footnotetext{
${ }^{11}$ OLS regressions were run to test whether or not this is the case. First, a regression was analyzed which only included the movers with a constant. Second, a regression was run which included the dummy variables without a constant. It was found that the coefficients were qualitatively the same. Thus, the dummy variable Stay $_{i j}$ effectively controls for the impact of "stayers."
} 
considered much in the migration literature (Cushing and Poot, 2004). Porojan (2001) is an exception in providing an analysis of trade flows between the European Union and potential trade partners using an adapted gravity model much different than that used in this paper.

Generally, a SAR will be estimated first followed by the SEM. If rho and lambda are both determined to be significantly different from zero, a GSAR which allows the possibility of both spatial dependence and spatial autocorrelation will be most appropriate. There are further tests to determine whether spatial autocorrelation exists including the Moran's Information Statistic and the Likelihood Ratio test. The null hypothesis of both of these tests is that there is no spatial autocorrelation. The Moran's I statistic is constructed as follows:

$$
I=\left[e^{\prime} W e\right] / e^{\prime} e
$$

where $W$ is the weight matrix in Equation 4 where $e$ is the residuals from OLS. The Likelihood Ratio test analyzes the difference between the log likelihood estimates from OLS and SEM. If either of these statistics is estimated to be significantly different from zero, then the null hypothesis is rejected in favor of spatial autocorrelation.

Both tests are conducted in this study. The Moran's I and the Likelihood Ratio tests yielded respective values of 38.11 and 2004.4, both of which far exceed the critical values for conventional levels of significance. ${ }^{12}$ The null hypothesis of no spatial

\footnotetext{
${ }^{12}$ The tests were run in Matlab Version 7and MS Windows XP 2002. For a more thorough discussion of these tests see Spatial Econometrics (Lesage, 1998). In particular, Equations 3.3 and 3.5 are taken from this source.
} 
autocorrelation is rejected. In addition, a SAR model was estimated which yielded a value of rho that is significantly different from zero. These outcomes indicate that the GSAR model is the appropriate model of the three for consistent and more efficient results. Equation 4 is a GSAR model. Regressions were analyzed for the SAR, SEM, and the GSAR, but for the sake of conciseness only the GSAR are reported herein. ${ }^{13}$

Schultz (1982) suggests that a polychotomous logistic method should be used for estimation of a gravity model. For this reason the dependent variable is specified in this manner. The log-odds ratio is found by taking the log of the probability of migrating from one location to another divided by the rate of nonmigration between these two locations. Migrationrate $_{i j}$ is found by dividing the amount of working-age migrants from the origin to the destination locality by the origin population at the beginning of the migration period. Table B.1 in the Appendix provides a detailed explanation of the variables and data sources used in this study.

Often logs are taken on the independent variables. In this analysis, logs are taken with respect to relative total populations, population densities, and incomes. The remaining variables are in levels. The explanatory variables are actually beginning of the period values since these are likely to be the driving forces of migration. Ln Population /Population ${ }_{i}$ and Ln Density /Density $_{i}$, are the values taken from 1995. The calculation of Population $_{j} /$ Population $_{i}$ has been explained above in discussing how to determine the at risk population. Density $y_{j}$ Density $y_{i}$ is the population densities calculated by dividing the total population in 1995 by total area in of the state in square miles.

\footnotetext{
${ }^{13}$ However, the other estimates are available upon request.
} 
Income $_{j}$ Income $_{i}$ is the mean income per capita averages between 1990 and 1995. Income per capita is easily obtained from the Bureau of Economic Analysis as are the Gross State Deflators (GSD). However, GSD is not useful for comparing the actual levels of cost of living between states. In the base year of its calculation (2000), the deflator is constrained to be equal to 100 for all states. Using this to compare the cost of living between states will result in faulty conclusions. For instance, the GSD implies that West Virginia, North Dakota, Kansas, and Oklahoma experienced higher costs of living in 1990 than California. However, the GSD may be reasonably used to measure the changes in cost of living. Up until 1990, a more reasonable measurement of cost-ofliving levels, the Geographical Cost of Living Index (GCLI), was constructed by McMahon and Chang (1991). It uses various methods to construct this index. In particular it is found that housing, due to its immobility, is the main driver of cost-ofliving differences between states. Using the GSD and the 1990 levels constructed by the GCLI, the cost-of-living values are estimated for each state from 1990 to 1995 for this analysis. These values are used to convert income from 1990 to 1995 to real income per capita and the mean during this period is taken for each state.

Economicfreedom $_{j}$ /Economicfreedom ${ }_{i}$ is the average values between 1990 and 1995. Economicfreedom $/$ Economicfreedom $_{i}$ in Equation 4 can be interpreted in two ways since regressions will be analyzed which include the index as a whole as well as the individual components of the index. In the former case it will be a 2,304 by 1 vector and the coefficient $\beta_{1}$ will be the estimate of the impact of relative economic freedom on migration flows. In the latter case it will be interpreted as a 2,304 by 8 matrix and the coefficient $\beta_{1}$ will be a vector of the eight estimated coefficients of each component of 
economic freedom. In particular, the variable names of the eight components analyzed

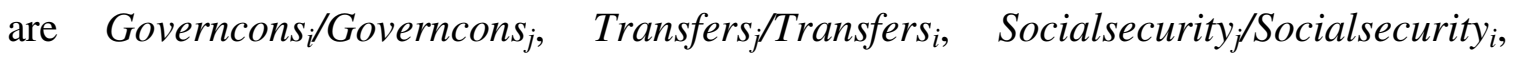
Taxrevenues $_{j} /$ Taxrevenues $_{i}, \quad$ Marginaltax $_{j} /$ Marginaltax $_{i}, \quad$ Minwage $_{j} /$ Minwage $_{i}$, Governmentemploy /Governmentemploy $_{i}$, and Uniondensity Uniondensity $_{i}$. These variables coincide with $1 \mathrm{~A}, 1 \mathrm{~B}, 1 \mathrm{C}, 2 \mathrm{~A}, 2 \mathrm{~B}, 3 \mathrm{~A}, 3 \mathrm{~B}$, and $3 \mathrm{C}$ in Table 1 . Again, 2C and $2 \mathrm{D}$ are not included in the decomposition because both of these are included as part of $2 \mathrm{~A}$ and are therefore not deemed to be redundant.

It should be noted that the economic freedom components will not be included as scores with the exception of $2 \mathrm{~B}$, the highest marginal income tax rate and the corresponding threshold at which it applies. For the remaining components, the raw data used to make the scores will be included. The interpretation of these is different. Relatively high levels of government consumption and higher marginal tax rates would coincide with lower economic freedom scores. Expecting Economicfreedom / $^{\prime}$ Economicfreedom $_{i}$ to positively impact migration flows is equivalent to expecting Governcons $_{i} /$ Governcons $_{j}$ and Transfers $_{j} /$ Transfers $_{i}$ to negatively impact migration flows.

Since both the tax rate and the threshold are important when considering the tax burden, merely including the tax rate will not sufficiently determine the impact. In order to analyze the burden in terms of the marginal tax rate and its threshold, the average score taken between 1990 and 1995 for each state is arbitrarily divided by ten. A higher score in this case would indicate a higher tax burden and a lower score a lower tax burden. This is done in order to make this variable more comparable to the other components and avoid confusion when interpreting the regression estimates. The analysis of the economic freedom components demonstrates the mixed response that individuals may 
have to economic freedom indicators. Freedom in terms of carrying out economic activities may be attractive to some, but some aspects of this freedom may conflict with other government policies that also tend to attract individuals such as income transfers and social programs. ${ }^{14}$ In aggregate, what are the effects of economic freedom? In theory the aggregate effect could be negative, positive or insignificant.

Employmentgrowthrate $_{j}$-Employmentgrowth El $_{i}$ is the difference in employment growth between 1990 and 1995 between the destination and the origin state. Using differences is a more logical way to analyze this variable than looking at relative rates of employment growth. When dividing Employmentgrowthrate Ey $_{j}$ Employmentgrowth, it creates problems with the data when one of the observations is negative. For instance, if Employmentgrowth $_{j}$ is 2 and Employmentgrowth Em $_{i}$ is 1 , then Employmentgrowth $_{j} /$ Employmentgrowth $_{i}$ is 2. However, if Employmentgrowth Emere $_{i}$ negative and even lower with a value of -1 , then Employmentgrowth $_{j} /$ Employmentgrowth $_{i}$ would be $-2 . \quad$ Retired $_{j} /$ Retired $_{i}$ is the 1990 census values and is the relative percentage of individuals that are over 65 . Precipitation $_{j} /$ Precipitation $_{i}$ is the relative difference between states in the amount of precipitation in inches taking the averages between 1971 and 2000 . Heatingdays $_{j} /$ Heatingdays $_{i}$ is the difference in the number of heating days. Heating days are found by taking all days in which the temperature is below 65 degrees Fahrenheit in different regions of a state and adding the difference between the temperatures and 65 degrees. For instance, a day with a temperature of 60 degrees would contribute five

\footnotetext{
${ }^{14}$ I would like to thank one of the anonymous referees for encouraging me to consider this fact.
} 
Table 3.3 Descriptive Statistics

\begin{tabular}{|c|c|c|c|c|}
\hline Variable & Mean & $\begin{array}{l}\text { Standard } \\
\text { Deviation }\end{array}$ & Maximum & Minimum \\
\hline Ln [Migrationrate $\mathrm{ij}_{\mathrm{ij}} /(1$-Migrationrate $\left.\mathrm{ij})\right]$ & -5.198 & 1.518 & 0.908 & -10.666 \\
\hline Ln Population $_{\mathrm{j}} /$ Population $_{\mathrm{i}}$ & 0.000 & 1.346 & 3.909 & -3.909 \\
\hline Ln Density $/$ Density $_{i}$ & 0.000 & 1.788 & 5.223 & -5.223 \\
\hline Ln Income $_{j} /$ Income $_{i}$ & 0.000 & 0.121 & 0.386 & -0.386 \\
\hline $\begin{array}{l}\text { Employmentgrowth }_{\mathrm{j}} \text {-Employmentgrowth } \\
\text { Economicfreedom }_{\mathrm{j}} / \text { Economicfreedom }_{\mathrm{i}}\end{array}$ & $\begin{array}{l}0.000 \\
1.006\end{array}$ & $\begin{array}{l}4.735 \\
0.108\end{array}$ & $\begin{array}{l}13.640 \\
1.484\end{array}$ & $\begin{array}{l}-13.640 \\
0.674\end{array}$ \\
\hline Retired $_{j} /$ Retired $_{i}$ & 1.020 & 0.204 & 2.103 & 0.475 \\
\hline Heatingdays $_{\mathrm{j}} /$ Heatingdays $_{\mathrm{i}}$ & 1.304 & 1.276 & 13.612 & 0.073 \\
\hline Precipitation $_{\mathrm{j}} /$ Precipitation $_{\mathrm{i}}$ & 1.260 & 0.935 & 6.331 & 0.158 \\
\hline Governmentcons $_{\mathrm{j}} /$ Governmentcons $_{\mathrm{i}}$ & 1.023 & 0.221 & 2.241 & 0.446 \\
\hline Transfers $_{j} /$ Transfers $_{i}$ & 1.097 & 0.501 & 4.475 & 0.223 \\
\hline Socialsecurity $_{\mathrm{j}} /$ Socialsecurity $_{\mathrm{i}}$ & 1.035 & 0.277 & 2.569 & 0.389 \\
\hline Taxrevenues $_{j} /$ Taxrevenues $_{i}$ & 1.007 & 0.121 & 1.420 & 0.704 \\
\hline Marginaltax $_{\mathrm{j}} /$ Marginaltax $_{\mathrm{i}}$ & 1.023 & 0.221 & 1.808 & 0.553 \\
\hline Minwage $_{\mathrm{j}} /$ Minwage $_{\mathrm{i}}$ & 1.022 & 0.213 & 1.951 & 0.513 \\
\hline Governmentemploy $/$ Governmentemploy $_{i}$ & 1.022 & 0.218 & 1.932 & 0.518 \\
\hline Uniondensity $_{\mathrm{j}} /$ Uniondensity $_{\mathrm{i}}$ & 1.151 & 0.644 & 5.259 & 0.190 \\
\hline Distance $_{\mathrm{ij}}$ & $1,181.173$ & 722.173 & 3,138 & 0.000 \\
\hline Distancesquared $_{\mathrm{ij}}$ & $1,916 \times 10^{3}$ & $2,111 \times 10^{3}$ & $9,847 \times 10^{3}$ & 0.000 \\
\hline
\end{tabular}

heating days to the annual total whereas a day with a temperature of 70 would contribute zero heating days. The lower the number, the warmer is the climate.

The distance variables Distance $_{i j}$ and Distancesquared ${ }_{i j}$, measure some of the costs of traveling from any given distance. The distance between principal cities for any two states is used. There are several reasons why the relationship might be nonlinear justifying the inclusion of the squared values (McCann, 2001). $\varepsilon_{\mathrm{ij}}$ is the error term. The expected signs of these two variables are $\delta_{1}<0$ and $\delta_{2}>0$. The distance variables are not included in logs due to the nature of this analysis. Clearly, the distance between states for 
all "Stayers" is equal to zero making log transformation impossible (i.e., the distance between Alabama and Alabama is zero, etc.)

It is expected that individuals move towards relatively highly populated regions $\left(\beta_{2}>0\right)$ and away from relatively dense regions $\left(\beta_{3}<0\right)$. It is expected that individuals migrate towards relatively higher mean incomes $\left(\beta_{4}>0\right)$, higher employment growth $\left(B_{5}>0\right)$, a higher percentage of retired individuals $\left(\beta_{6}>0\right)$, warmer weather $\left(\beta_{7}<0\right)$, and less precipitation $\left(\beta_{8}<0\right)$. The justification for inclusion of Retired $_{j} /$ Retired $_{i}$ and the expected positive sign is to pick up any unmeasured determinants of wellbeing not picked up by the remaining variables.

Table 3.3 includes summary statistics of the dependent and independent variables including the mean, standard deviation, maximum, and minimum values. The descriptive statistics for migration flows do not include "stayer" observations in the calculations.

\subsection{Empirical Results}

Table 3.4 displays the results for the estimation of Equation 4 using a general spatial autoregressive estimator (GSAR) with the log-odds of migration as the dependent variable. Most of the results are as expected. The first column includes all of the variables in Equation 4 and the second column excludes income and employment growth to observe the impact of economic freedom without these indicators of economic wellbeing. ${ }^{15}$

\footnotetext{
${ }^{15}$ The impact of relative median house prices was analyzed in some regressions, but it was insignificant. The cost-of-living measurements used to calculate real mean income per capita are highly correlated with house prices since this is the main determinant of cost-of-living differences between states. For this reason, median house price was deemed to be an unnecessary inclusion.
} 
EconomicFreedom $_{j} /$ Economicfreedom $_{i}$, which is the variable of most interest in this study, yields the expected positive coefficient (0.769) and is significant. It is also significant and positive (1.617) in the second column when income and employment growth are excluded. Economic theory and empirical evidence demonstrate that economic freedom influences income levels and the growth of employment. States with

Table 3.4 GSAR Estimation for Equation 3.4 with the Log-Odds Ratio of the Migration Rate as the Dependent Variable

\begin{tabular}{|c|c|c|}
\hline Variable & Coefficient & lute values) \\
\hline EconomicFreedom $_{\mathrm{j}} /$ EconomicFreedom $_{\mathrm{i}}$ & $\begin{array}{l}0.769 * * * \\
(3.67)\end{array}$ & $\begin{array}{l}1.617 \text { *** } \\
(8.40)\end{array}$ \\
\hline Ln Population $_{\mathrm{j}} /$ Population $_{\mathrm{i}}$ & $\begin{array}{l}-0.133^{* * * *} \\
(7.82)\end{array}$ & $\begin{array}{l}-0.095^{* * *} \\
(5.62)\end{array}$ \\
\hline Ln Density ${ }_{j} /$ Density $_{i}$ & $\begin{array}{l}-0.073^{* * * *} \\
(3.10)\end{array}$ & $\begin{array}{l}-0.118^{* * * *} \\
(5.60)\end{array}$ \\
\hline Ln Income $_{j} /$ Income $_{i}$ & $\begin{array}{l}1.643 * * * \\
(8.91)\end{array}$ & - \\
\hline Employmentgrowth $_{\mathrm{j}}$ Employmentgrowth $_{\mathrm{i}}$ & $\begin{array}{l}0.056^{* * * *} \\
(8.48)\end{array}$ & - \\
\hline Retired $_{j} /$ Retired $_{i}$ & $\begin{array}{l}0.796 * * * \\
(8.43)\end{array}$ & $\begin{array}{l}0.879 * * * \\
(9.06)\end{array}$ \\
\hline Heatingdays $_{\mathrm{j}} /$ Heatingdays $_{\mathrm{i}}$ & $\begin{array}{l}0.08^{* * * *} \\
(3.38)\end{array}$ & $\begin{array}{l}0.078^{* * * *} \\
(3.24)\end{array}$ \\
\hline Precipitation $_{\mathrm{j}} /$ Precipitation $_{\mathrm{i}}$ & $\begin{array}{l}-0.061 \\
(1.47)\end{array}$ & $\begin{array}{l}-0.157^{* * *} \\
(3.74)\end{array}$ \\
\hline Distance $_{\mathrm{ij}}$ & $\begin{array}{l}-0.002 * * * \\
(12.66)\end{array}$ & $\begin{array}{l}-0.002 * * * \\
(12.69)\end{array}$ \\
\hline Distancesquared $_{\mathrm{ij}}$ & $\begin{array}{l}6 \times 10^{-6 * * *} \\
(10.84)\end{array}$ & $\begin{array}{l}6 \times 10^{-6 * * *} \\
(10.88)\end{array}$ \\
\hline Stay $_{\mathrm{ij}}$ (Dummy for non-movers) & $\begin{array}{l}2.533 * * * \\
(29.23)\end{array}$ & $\begin{array}{l}2.543 * * * \\
(28.83)\end{array}$ \\
\hline Constant & $\begin{array}{l}-5.059 * * * \\
(19.88)\end{array}$ & $\begin{array}{l}-5.932 * * * \\
(24.04)\end{array}$ \\
\hline rho (spatial dependence) & $\begin{array}{l}0.057 * * * \\
(7.188)\end{array}$ & $\begin{array}{l}0.045^{* * * *} \\
(4.02)\end{array}$ \\
\hline lambda (spatial autocorrelation) & $\begin{array}{l}0.73 * * * \\
(87.16)\end{array}$ & $\begin{array}{l}0.729 * * * \\
(86.81)\end{array}$ \\
\hline Adjusted Rsquared & 0.875 & 0.868 \\
\hline
\end{tabular}

$* * * 1 \%, * * 5 \%, * 10 \%$ probability for a two-tailed test

Regressions were run using Matlab Version 7 and MS Windows XP 2002 
persistently more economic freedom will experience higher levels of income and more rapid employment growth. When the income and employment growth variables are included in the model along with economic freedom as in column one of Table 3.4, this indirect impact of economic freedom via income and employment growth is not as apparent. If this indirect impact is important, the estimated impact of economic freedom will be substantially larger in an estimate that excludes the income and employment growth variables. Column two clearly demonstrates this to be the case. When the income and employment growth variables are excluded from the model, the economic freedom variable is significant with a much higher coefficient. The implication is that states with more economic freedom achieve higher income levels and grow more rapidly and that these indirect effects of economic freedom also influence migration choices. ${ }^{16}$

The negative coefficients on Ln Population $_{j} /$ Population $_{i}(-0.133,-0.095)$ and Ln Density $_{j} /$ Density $_{i}(-0.073,-0.118)$ are consistent with the trend of movement away from more populated areas in the United States. The estimate of Ln Income $_{j} /$ Income $_{i}$ is positive and significant (1.643). As the relative income of the destination state to the origin state increases by $1 \%$, the odds ratio of migrating to the destination state increases by about $1.6 \%$ according to these estimates. Employmentgrowth ${ }_{j}$-Employmentgrowth E $_{i}$ is positive and significant $(0.056)$ as well.

The positive coefficients on Retired $_{j} /$ Retired $_{i}(0.796,0.879)$ indicate that a higher percentage of retired individuals attracts migrants. Both of the climate variables Heatingdays $_{j} /$ Heatingdays $_{i}(0.08,0.078)$ and Precipitation $_{j} /$ Precipitation $_{i} \quad(-0.061$,

\footnotetext{
${ }^{16}$ All of the control variables in Equation 4 with the exception of income and employment growth were regressed on income and employment growth, respectively. The coefficient for economic freedom was positive and significant as expected.
} 
-0.157) are significant, and the distance variables Distance $_{i j}$ and Distancesquared $_{i j}$, are significant with the expected signs (-0.002 and $0.6 \times 10^{-6}$ respectively). ${ }^{17}$

Table 3.5 includes the estimates of Equation 3.4 when decomposing the index into the eight components of economic freedom explained above. Again, these variables are not calculated scores with the exception of Marginaltax /Marginaltax $_{i}$ which is explained above. They are the actual values of the indicators used to calculate the scores. As discussed above, the coefficients of these should be interpreted differently. For instance, a high level of government consumption and a relatively high tax burden would coincide with a lower economic freedom score. The first column includes relative income and employment growth whereas the second column excludes these.

All of the components are significant in both regressions with the exception of Transfer $_{j} /$ Transfers $_{i}$ and Taxrevenues TTaxrevenues $_{i}$ which are not significant in either equation. Governcons /Governconi $_{j}(0.377,0.262)$ and Socialsecurity /Socialsecurity $_{i}$ $(0.655,0.683)$ both have a positive impact on migration flows. This seems to indicate that relatively higher government expenditures and transfer payments seem to attract individuals in aggregate. On the other hand, Marginaltax ${ }_{j} \operatorname{Marginaltax}_{i}(-0.193,-0.324)$, Minwage $_{j}$ Minwage $_{i}$ (-1.323, -1.362), Governmentemploy $/$ /Governmentemploy $_{i}$ (-1.109, -1.151), and Uniondensity Uniondensity $_{i}(-0.156,-0.185)$ tend to result in a lower likelihood of migration to a given state. The complete findings indicate that individuals tend to move to states with lower tax burdens in the form of lower marginal tax rates for the highest income bracket and high income thresholds and policies that are less

\footnotetext{
${ }^{17}$ The output from Matlab only provides six decimals. However, this coefficient is statistically significant. For this reason, Distancesquared $_{i j}$ is rescaled for estimation purposes.
} 
Table 3.5 GSAR Estimation for Equation 4 with the Log-Odds Ratio of the Migration Rate as the Dependent Variable and Economic Freedom Decomposed

\begin{tabular}{|c|c|c|}
\hline \multicolumn{3}{|c|}{$\begin{array}{l}\text { Note: the i subscript indicates origin state and the } \mathrm{j} \text { subscript indicates destination state } \\
\text { Variable } \\
\text { Coefficients (t-statistic absolute values) }\end{array}$} \\
\hline Governmentcons $_{\mathrm{j}} /$ Governmentcons $_{\mathrm{i}}$ & $\begin{array}{l}0.377 * * * \\
(3.64)\end{array}$ & $\begin{array}{l}0.262^{* *} \\
(2.59)\end{array}$ \\
\hline Transfers $_{j} /$ Transfers $_{i}$ & $\begin{array}{l}-0.017 \\
(0.291)\end{array}$ & $\begin{array}{l}-0.083 \\
(1.41)\end{array}$ \\
\hline Socialsecurity $_{\mathrm{j}} /$ Socialsecurity $_{\mathrm{i}}$ & $\begin{array}{l}0.655^{* * * *} \\
(5.01)\end{array}$ & $\begin{array}{l}0.683 * * * \\
(5.23)\end{array}$ \\
\hline Taxrevenues $_{j} /$ Taxrevenues $_{i}$ & $\begin{array}{l}-0.324 \\
(1.04)\end{array}$ & $\begin{array}{l}-0.064 \\
(0.277)\end{array}$ \\
\hline Marginaltax $_{\mathrm{j}} /$ Marginaltax $_{\mathrm{i}}$ & $\begin{array}{l}-0.193 * * \\
(2.29)\end{array}$ & $\begin{array}{l}-0.324 * * * \\
(4.33)\end{array}$ \\
\hline Minwage $_{\mathrm{j}} /$ Minwage $_{\mathrm{i}}$ & $\begin{array}{l}-1.323^{* * * *} \\
(6.17)\end{array}$ & $\begin{array}{l}-1.362 * * * \\
(8.15)\end{array}$ \\
\hline Governmentemploy $_{\mathrm{j}} /$ Governmentemploy $_{\mathrm{i}}$ & $\begin{array}{l}-1.088 * * * \\
(8.38)\end{array}$ & $\begin{array}{l}-1.151 * * * \\
(8.93)\end{array}$ \\
\hline Uniondensity $_{\mathrm{j}} /$ Uniondensity $_{\mathrm{i}}$ & $\begin{array}{l}-0.156^{* * * *} \\
(3.82)\end{array}$ & $\begin{array}{l}-0.185^{* * * *} \\
(4.50)\end{array}$ \\
\hline Ln Population $_{\mathrm{j}} /$ Population $_{\mathrm{i}}$ & $\begin{array}{l}-0.105^{* * * *} \\
(6.02)\end{array}$ & $\begin{array}{l}-0.1 * * * \\
(5.73)\end{array}$ \\
\hline Ln Density ${ }_{j} /$ Density $_{i}$ & $\begin{array}{l}-0.159 * * * \\
(6.03)\end{array}$ & $\begin{array}{l}-0.214 * * * \\
(8.87)\end{array}$ \\
\hline Ln Income $_{j} /$ Income $_{i}$ & $\begin{array}{l}0.743 * * \\
(2.19)\end{array}$ & - \\
\hline Employmentgrowth $_{\mathrm{j}}$-Employmentgrowth ${ }_{\mathrm{i}}$ & $\begin{array}{l}0.04 * * * \\
(5.28)\end{array}$ & - \\
\hline Retired $_{j} /$ Retired $_{i}$ & $\begin{array}{l}0.339 * * * \\
(2.92)\end{array}$ & $\begin{array}{l}0.246^{* *} \\
(2.13)\end{array}$ \\
\hline Heatingdays $_{\mathrm{j}} /$ Heatingdays $_{\mathrm{i}}$ & $\begin{array}{l}0.083^{* * * *} \\
(3.44)\end{array}$ & $\begin{array}{l}0.076^{* * * *} \\
(3.14)\end{array}$ \\
\hline Precipitation $_{\mathrm{j}} /$ Precipitation $_{\mathrm{i}}$ & $\begin{array}{l}0.004 \\
(0.09)\end{array}$ & $\begin{array}{l}-0.021 \\
(0.474)\end{array}$ \\
\hline Distance $_{\mathrm{ij}}$ & $\begin{array}{l}-0.002 * * * \\
(10.91)\end{array}$ & $\begin{array}{l}-0.002 * * * \\
(11.07)\end{array}$ \\
\hline Distancesquared $_{\mathrm{ij}}$ & $\begin{array}{l}6 \times 10^{-6 * * * *} \\
(9.43)\end{array}$ & $\begin{array}{l}6 \times 10^{-6} * * * \\
(9.56)\end{array}$ \\
\hline Stay $_{\mathrm{ij}}$ (Dummy for non-movers) & $\begin{array}{l}2.499 * * * \\
(27.20)\end{array}$ & $\begin{array}{l}2.49 * * * \\
(27.19)\end{array}$ \\
\hline Constant & $\begin{array}{l}-1.719 * * * \\
(6.10)\end{array}$ & $\begin{array}{l}1.468 * * * \\
(5.21)\end{array}$ \\
\hline rho (spatial dependence) & $\begin{array}{l}0.076^{* * * *} \\
(6.97)\end{array}$ & $\begin{array}{l}0.074 * * * \\
(6.92)\end{array}$ \\
\hline lambda (spatial autocorrelation) & $\begin{array}{l}0.73 * * * \\
(84.41)\end{array}$ & $\begin{array}{l}0.73 * * * \\
(86.18)\end{array}$ \\
\hline $\begin{array}{l}\text { Adjusted Rsquared } \\
\mathrm{N}=2,304\end{array}$ & 0.8809 & 0.8795 \\
\hline
\end{tabular}


constraining in terms of labor and hiring decisions. Heatingdays $s_{j} /$ Heatingdays $_{i}$ is positive and significant which is not in accordance with the hypothesized outcome. This result implies that individuals tend towards states with colder climates. Precipitation $_{j} /$ Precipitation $_{i}$ is insignificant. All the remaining coefficients are as expected in terms of signs and significance. The estimates for the spatial effects (rho and lambda) are significant in both regressions as expected.

As far as the magnitudes of the coefficients in column one is considered in Table 3.5, Ln Income $_{j}$ Income $_{i}$ (0.743) has the greatest impact on migration followed by Ln Population $_{j}$ Population $_{i}$ (-0.105). For the variables estimated in levels, Minwagej/Minwagei (-1.323) has the greatest impact followed by Governmentemployj/Governmentemplyi (-1.088), Socialsecurityj/Socialsecurityi (0.655), and Governmentconsj/Governmentconsi (0.377). However, due to the difference in the units used in these measurements, it is not easy to determine which indicators are more important in discovering the determinants of migration. The interpretation of the coefficients of logged variables can be interpreted as the elasticities of the likelihood of migrating from any given state $\mathrm{i}$ to any given state $\mathrm{j}$ with respect to the given variable. For example, the coefficient (-0.105) on Ln Population $_{j} /$ Population $_{i}$ is interpreted as the percentage change in the odds ratio of migrating from state $i$ to state $j$ given a one-percent increase in the relative population between state $\mathrm{j}$ and state $\mathrm{i}$. The coefficient of the variables in levels is the percentage increase in the odds ratio of migration given a oneunit increase in the variable. An increase in Minwage $/$ Minwage $_{i}$ of one unit would be estimated to decrease the odds ratio of migration by about $1.3 \%$. 
Table 3.6 displays an effort to make these impacts more comparable. The marginal impact of increasing a given measure by the estimated standard deviation of each measure is analyzed instead of analyzing the effects of a one-percent or one-unit change in the variables. In addition, the variables are divided into two groups depending on whether they are estimated in logs or in levels. This may be a more intuitive analysis in terms of comparing coefficients. The coefficients in Table 3.6 are taken from the estimates shown in the first column of Table 3.5 and the standard deviations are taken from the summary statistics in Table 3.3. The asterisks indicate that coefficients are statistically significant. For instance, if the distance between two states were to change by one mile, the likelihood of migration occurring between these states will only decrease by $-0.002 \%$ which would appear to be minimal despite the significance of the distance variables. However, if the impact of distance is analyzed in terms of the standard deviation (approximately 722 miles), then the likelihood of migration occurring decreases by approximately $-1.1 \%$.

In terms of standard deviations, distance seems to be the most important determinant of migration compared to all of the variables in levels. Minwage ${ }_{j} /$ Minwage $_{i}$ $(-0.282)$ has the greatest impact out of the economic freedom components followed by Governmentemploy $_{j} /$ Governmentemploy $_{i} \quad(-0.237)$ and Socialsecurity /Socialsecurity $_{i}$ (0.182). Employmentgrowth -Employmentgrowth $_{i}$ seems to have a larger impact than most of these (0.189). This is logical since individuals are likely driven more by employment opportunities than other factors. However, it is likely that policies related to labor freedom and taxation are important determinants of employment. 
Table 3.6: Analysis of a Standard Deviation Increase in the Values of the Variables

\begin{tabular}{|c|c|c|c|}
\hline Variable & $\begin{array}{l}\text { Coefficient } \\
\text { (1) }\end{array}$ & $\begin{array}{l}\text { Standard Deviation } \\
\text { (2) }\end{array}$ & $\begin{array}{c}\text { Impact of Standard } \\
\text { Deviation Increase } \\
(1)^{*}(2)\end{array}$ \\
\hline $\begin{array}{l}\text { Logs: } \\
\text { Population }_{\mathrm{j}} / \text { Population }_{\mathrm{i}} \\
\text { Density }_{\mathrm{j}} \text { /Density }_{\mathrm{i}} \\
\text { Income }_{\mathrm{j}} / \text { Income }_{\mathrm{i}}\end{array}$ & $\begin{array}{c}-0.105^{*} \\
-0.159 * \\
0.743 *\end{array}$ & $\begin{array}{l}1.346 \\
1.788 \\
0.121\end{array}$ & $\begin{array}{c}-0.141 \\
-0.285 \\
0.09\end{array}$ \\
\hline  & $\begin{array}{c}0.377^{*} \\
-0.017 \\
0.655^{*} \\
-0.324 \\
-0.193^{*} \\
-1.323^{*} \\
-1.088^{*} \\
-0.156^{*} \\
0.04^{*} \\
0.339^{*} \\
0.083^{*} \\
0.004 \\
-0.002^{*} \\
0.6 \times 10-6^{*}\end{array}$ & $\begin{array}{c}0.221 \\
0.501 \\
0.277 \\
0.121 \\
0.221 \\
0.213 \\
0.218 \\
0.644 \\
4.735 \\
0.204 \\
1.276 \\
0.935 \\
- \\
- \\
722.17 \\
\end{array}$ & $\begin{array}{c}0.083 \\
-0.009 \\
0.182 \\
-0.039 \\
-0.043 \\
-0.282 \\
-0.237 \\
-0.101 \\
0.189 \\
0.069 \\
0.106 \\
0.004\end{array}$ \\
\hline
\end{tabular}

The impact of economic freedom as measured by the Economic Freedom of North America Index is positive and significant in determining migration flows. However, this could be due to its relationship to the income and employment variables. Given the results in the second column of Table 3.4, it would be difficult to conclude that economic freedom does not, at the very least, impact migration flows indirectly.

Most of the components do have a significant impact according to the estimates in this paper. Governmentcons $s_{j} /$ Governmentcons $_{i}$ appear to yield a negative response. This finding might be interpreted to indicate that transfers of income and higher government expenditures are effective means of increasing the welfare of individuals. Yet the impact 
of high union density, minimum wage laws, and a high percentage of individuals working in the public sector is negative. In other words, a larger government may attract many individuals, but it also appears to motivate outward migration of valuable labor and capital. For instance, as the government increases its influence and spending it must hire more individuals from the private sector. Large government expenditures decrease labor freedom which results in outward migration of many productive individuals. This is merely one interpretation of the results.

In terms of market-preserving federalism, these outcomes are not necessarily desirable. As mentioned above, the United States is considered to be one of the more federalistic nations. Yet, it does not meet the standards set by Weingast (1995) as a market-preserving federation. It fails in this regard due to the lack of separation of authority in economic matters between the federal and state levels of government. The national government has the tendency to spend large amounts to bail out state governments when lobbied to do so. If this national policy is relatively uniform across states, individual state governments have less incentive to weigh the benefits versus the costs of their policy decisions. For instance, although valuable labor and capital may be driven outward by a state's policies, political officials have little incentive to change these policies.

Although individuals may maximize utility through migration in the short run, in the long run migration will no longer be as effective. There are two reasons for this. First, these policies may attract individuals from other states that favor income transfers and social programs. These inmigrants will seek to perpetuate such policies through their voting behaviors. Second, as these policies drain the given state from valuable factors of 
production, local political officials will seek the assistance of federal officials. In a market-preserving federation, such efforts would be denied, prompting local officials to weigh the benefits and costs of economic policy decisions. In contrast, if the federal government answers the call for assistance, they will eventually need to raise revenues by increasing the burden on states with more productive economic resources. The opportunity for individuals that prefer economic freedom to improve utility through migration is lessened as economic authority becomes more centralized. In this case, it becomes difficult for markets to continue and total welfare is lessened in the long run. The allegation that internal migration within Canada is much smaller than within the United States (Greenwood, 1997) could be due to the relative centralization of economic authority in the former.

If interpreted in this manner, the findings are consistent with the literature on market-preserving fiscal federalism. As long as economic authority is not sufficiently decentralized, it becomes more difficult for political officials to carry out efficient policies. Thus, markets which enhance overall utility in the long run are endangered. Suggestions to solve this problem are to impose constitutional restrictions on the involvement of the federal government in state economic matters (Holcombe 1994). In this manner, politicians are induced to weigh the benefits and costs of their policies and migration will be more likely to result in more efficient outcomes and higher total welfare in the long run.

This argument by no means can be fully demonstrated by the results in this chapter. There are many different interpretations for the results and further research is needed to demonstrate the correct story behind these findings. 


\subsection{Conclusion and Policy Implications}

The objective of this paper has been to analyze the impact of free market institutions on migration flows between states. In particular, the effect of policies that restrict economic freedom on migration flows is measured in U.S. states estimating a gravity model. The theoretical model of interest is that of Tiebout (1956) which claims that individuals will manifest their preferences through migration. Using the Economic Freedom of North America Index (Karabegovic and McMahon, 2005) and a general spatial autoregressive estimator it is found that individuals are induced to migrate to states with relatively higher government expenditures and social security, relatively smaller impediments in the labor market, and smaller tax burdens.

Migration has often been suggested as a way of measuring the ability of individuals to locate to areas that increase their utility. It also holds important implications in terms of analyzing the effect of institutions and federalism in making public policy. Weingast (1995) and Qian and Weingast (1997) argue that decentralization of economic authority from the national to local governments causes political officials to align their behavior to the preferences of constituents. The ability of individuals to migrate from one state to another demonstrates that individuals can and do manifest these preferences through migration. The implication suggested by Tiebout (1956), Weingast (1995), and Qian and Weingast (1997) indicates that their may be improvements in market efficiency and total utility by decentralizing economic authority. Holcombe (1994) suggests instituting constitutional rules limiting power at the federal level which would allow these gains to occur due to greater competition between regions. 


\title{
CHAPTER 4
}

\section{INCOME INEQUALITY AND ECONOMIC FREEDOM IN THE U.S. STATES}

\author{
"Although under competition the probability that a man \\ who starts poor will reach great wealth is much smaller \\ than is true of the man who has inherited property, it is not \\ only possible for the former, but the competitive system is \\ the only one where it depends solely on him and not on the \\ favors of the mighty, and where nobody can prevent a man \\ from attempting to achieve this result...And who will deny \\ that a world in which the wealthy are powerful is still a \\ better world than one in which only the already powerful \\ can acquire wealth?”
}




\section{CHAPTER 4}

\section{INCOME INEQUALITY AND ECONOMIC FREEDOM IN THE U.S. STATES ${ }^{18}$}

\subsection{Introduction}

Decades ago, economic research generally considered capitalism and socialism as alternative and discrete forms of economic organization. In reality economies tend to lie somewhere on a continuum between these two extremes. What differs on this continuum is the degree to which governments tend to use command and control policies to intervene into the private sector. Some socialist economies like North Korea are closer to pure socialism, while others like China have considerably more market aspects. Others which used to be more like North Korea have even moved to the other side of the continuum, like the former Soviet Republics of Estonia, Latvia, and Slovenia that have adopted radical pro-market reforms. On the other hand, most market-based economies have a much larger degree of government control and intervention than is envisioned under pure laissez-faire capitalism.

Approximately a decade ago, a significant advance in our understanding of this continuum was the publication of the Economic Freedom of the World index by James Gwartney and Robert Lawson (first published in 1996, now updated annually). In this publication, they derive a single index number for each country that places them on a continuum from zero to ten, where ten represents the highest degree of reliance on laissez-fare capitalism. In effect the index condenses the degree of 'economic freedom'

\footnotetext{
18 This chapter is based on Ashby and Sobel (2006)
} 
individuals have in a geographic area in several key categories like low taxes, low regulations, and secure property rights into a single number.

Studies using these indices such as Farr, Lord, and Wolfenbarger (1998), Gwartney, Lawson, and Holcombe (1999), Cole (2003), and Powell (2003) have consistently shown that countries with higher economic freedom scores not only have larger per capita incomes, but also tend to have higher rates of economic growth. Other studies have examined how this index correlates with everything from human selfperceived well being to health indicators, human migration, the productivity of investment, the level of entrepreneurship, and the degree of income inequality (Esposto and Zaleski, 1999, Norton, 2003; Melkumian, 2004; Ayal and Karras, 1998; Dawson, 1998; Ovaska and Sobel, 2005; Berggren, 1999; Grubel, 1998; Scully, 2002).

More recently, Amela Karabegovic and Fred McMahon (2005) released their Economic Freedom of North America ranking U.S. states with respect to each other in terms of their degree of free-market orientation. ${ }^{19}$ The differences among states occurs because state and local policies also impact the degree of 'economic freedom' individuals enjoy. The variance across states, however is obviously much less than the difference among countries. The international index differs among countries in more categories, such as monetary stability, tariff policy, and conscription. These categories simply are not relevant when making comparisons among sub-regions within a single country. The degree of economic freedom in each state is, however, impacted by the federal government's level of involvement in that state (e.g., in government employment measures in each state).

\footnotetext{
${ }^{19}$ The index also includes rankings for Canadian provinces.
} 
The empirical literature using the Economic Freedom of North America Index has mirrored the previous literature using the international freedom index. Explained variations in the rates of economic growth, entrepreneurship, and migration, for example, have for the most part carried over to cross-state analysis with equally significant results (Karabegovic, Samida, Schlegel, and McMahon, 2003; Kreft and Sobel, 2005; Ashby, 2007). ${ }^{20}$ In this paper we conduct the first analysis of how differences in economic freedom among U.S. states impacts income between the lowest, middle, and highest income quintiles and inequality between the highest and lowest income quintiles.

There are two main reasons why a similar analysis using U.S. state-level data is worthwhile. First, the two main studies on this subject using the international freedom index, both of which appeared in Public Choice, have found strikingly opposite results, and our analysis may help to clarify the mixed results. Berggren (1999), for example, finds that higher levels of economic freedom are associated with higher income inequality, while Scully (2002) finds that higher levels of economic freedom are associated with lower income inequality (although changes in freedom are found to work in the opposite direction). ${ }^{21}$ Second, while it seems obvious that the huge differences in institutions across countries will impact income inequality, it isn't so clear whether the smaller variation in policies among U.S. states can have a measurable impact. Can improvements in income inequality be used as a justification for smaller pro-market

\footnotetext{
${ }^{20}$ With regard to migration, the outcomes are not fully comparable. Internationally, Melkumian (2004) finds that higher economic freedom in the source country increases migration flows to the United States, but does not analyze whether individuals move to locations with higher economic freedom. At the state level, Ashby (2006) demonstrates that individuals migrate into states with relatively higher levels of economic freedom.

${ }^{21}$ Adding to the complexity, Berggren (1999) also includes a measure of the change in economic freedom, and finds it to be associated with lower income inequality.
} 
policy reforms at the state level, or is this argument applicable only to national-level institutional reforms?

In theory, economic freedom could improve inequality or lead to an increase in inequality. The first issue to analyze is to determine whether or not economic freedom benefits individuals at all levels of income. Do individuals at the lower end of the distribution benefit as well, or are the benefits fully captured by the wealthiest members of society? If the lower income earners do benefit from economic freedom, do they benefit to the extent that their share of total income increases, decreases, or does it stay the same? It is possible to think that individuals at the lower end might benefit more than the wealthiest of individual from policies changes which facilitate entrepreneurial activities and entry into different vocations. Instead of having to beg for their bread due to lack of opportunities, many of these may be more likely to produce a surplus of loaves if the costs of doing so are reduced and thus greatly increase their wellbeing. Of course, for states with low levels of economic freedom to begin with, significant changes may not be enough to benefit these individuals. Therefore, there is reason to think that the initial level of economic freedom is important as well, if not more important.

We begin our paper with a brief review of the previous research examining income inequality at the international level using the Economic Freedom of the World Index (EFW). We then perform similar regressions using the Economic Freedom of North America Index (EFNA), and discuss how the results compare. Additionally, we perform an analysis of how economic freedom not only impacts relative measures of income inequality, but also the absolute mean income levels within the lowest, middle, and highest income quintiles. We end with concluding remarks. 


\subsection{Literature Review}

Despite the myriad of studies which analyze international economic freedom and its relationship to income levels and economic growth, only a few studies exist which analyze the impact on income inequality. ${ }^{22}$ Berggren (2003) provides a recent overview of the benefits of economic freedom and discusses the cross-national studies of the impact economic freedom on inequality. Numerous studies on inequality at the state level exist (Partridge, 2006; Partridge, Partridge and Rickman, 1998; Partridge, Rickman, and Levernier, 1996; Bishop, Formby, and Thistle, 1992; Stano, 1981). The relationship between inequality and income growth is ambiguous in the literature (Partridge, 2006). There has been much discussion on this issue and the proper measurements of inequality. For the purpose of this study, we will focus on the measurement of inequality between the share of income held by the highest income quintile to the share held by the lowest quintile comparing our results to the findings of two papers published in Public Choice.

In the first study on this issue, Berggren (1999) finds that countries with a positive change in economic freedom between 1975 and 1985 experienced a reduction in income inequality as a result. Specifically, the share of income held by the lowest quintile rose while the share held by the highest quintile fell. In addition, Berggren (1999) finds a somewhat counterintuitive result-that while changes (increases) in economic freedom were associated with less income inequality, the levels of economic freedom in 1985 (at the end of the sample period) were associated with more income inequality. Berggren (2003) offers an explanation for his result that changes in economic freedom lessen

\footnotetext{
${ }^{22}$ Results are mixed for studies which analyze the impact of economic growth on inequality. Most recently, Forbes (2000) and Scully (2002) find that higher economic growth of market income increases inequality. Others find the relationship between the two to be negative (Alesina and Perotti, 1994; Alesina and Rodrik, 1994; Person and Tebelli, 1994; Birdsall, Ross and Sabot, 1995; and Clarke, 1995).
} 
inequality, while higher levels of economic freedom increase inequality based on an argument regarding the extent of redistributive government policies.

Scully (2002), however, finds that higher levels of economic freedom result in less inequality, opposite of the finding of Berggren (for the level of freedom). Scully finds that the share of income held by the lowest two quintiles is positively impacted whereas the share held by the highest two quintiles is lowered. Scully argues that his results differ due to the fact that Berggren fails to adjust for differences in the unit or basis of the sample upon which the inequality is measured. ${ }^{23}$

Grubel (1998) turns the equation around, asking whether levels of income inequality in a country can explain a country's level of economic freedom and economic growth. He concludes that higher inequality is associated with higher economic freedom. And while Grubel reverses the causal direction, his results would seem to be more consistent with Berggren's results. However, Grubel's study includes only countries with income levels above $\$ 17,000$, significantly reducing the sample to only 17 countries. Thus, it is unclear to what extent Grubel's results can be generalized to the rest of the world.

\subsection{Data and Methodology}

We now turn to our analysis of how state-level economic freedom impacts state-level income inequality within the United States. Our analysis is made possible by the release of new income inequality study from Bernstein, McNichol, and Lyons (2006) of the

\footnotetext{
${ }^{23}$ Scully (2002) explains that different countries calculate income distribution measures differently, and he adjusts for this by including dummy variables to account for which technique the country uses to construct its index, while Berggren (1999) does not.
} 
Economic Policy Institute. The study provides data on the absolute levels of income by quintile for three time periods: 1980-82, 1990-92, and 2001-03 (each of the three observations is an average over the three year window listed). Their data is derived from the Bureau of the Census' March Current Population Survey (CPS). In their definition, family income includes not only wages and salaries, but also other sources of cash income such as interest income and cash benefits, including veterans' assistance, welfare payments, and child support income. Other Census Bureau data on tax liabilities and credits, realized capital gains and losses, and the market value of near-cash benefits are then used to construct a measure of post-tax and transfer income on which their study is based. $^{24}$

As was discussed in the introduction, we use the Economic Freedom of North America Index from Karabegovic and McMahon (2005). Because the income data is a three year average, a similar computation is done with the freedom index. ${ }^{25}$ This index is made up of three major components: size of government, takings and discrimination, and labor market regulation. While we generally use the overall index in our analysis, we will also explore the component area scores individually. We restrict our sample to the 48 continental U.S. states.

For control variables we adopt similar measures as the previous studies, and include in our regressions the percentage of individuals with a high school education, the percentage living in a metropolitan area, and median income. Finally, we include dummy

\footnotetext{
${ }^{24}$ They exclude only the value of public health care benefits (e.g. Medicare and Medicaid) because of the lack of a generally accepted method for imputing the values.

${ }^{25}$ With the exception of the 1980-82 measure, for which we use 1981 to 1983 because 1981 is the first year for which the economic freedom score is available.
} 
variables for geographic regions within the United States. Our analysis examines how economic freedom impacts income and inequality, holding these other factors constant. All variables, their sources, and descriptive statistics are provided in the Appendix.

The specific measures of income and income inequality we use as dependent variables are: the absolute mean income levels within the lowest, middle, and highest quintiles; the cumulative 20 year percentage income growth for each of these quintiles; the shares of income held by the lowest, middle, and highest quintiles; and the ratio of the highest to lowest quintile's income shares. Although there are many other measurements of income inequality, we focus on what was used by Scully and Berggren for comparison's sake. The only exception is that we do not use the Gini coefficient. All data is in constant 2002 dollars. A quick examination of the raw data suggests some interesting correlations. The most visually interesting relationships visible in the raw data are in the scatter plots of quintile income growth rates when compared with changes in economic freedom scores. Figure 4.1 shows this for all three of the income groups we consider here. There is a fairly strong positive relationship in all three plots, even before controlling for other variables. On the other hand, the similar plots using the levels of economic freedom don't reveal obvious visible patterns. Thus, it appears that of the results from previous literature, Berggren's result (that changes in freedom are positive) might be the most likely to be confirmed. We now turn to regression methodology to uncover these relationships more precisely, after controlling for the other factors. 
Figure 4.1 The Change in Economic Freedom and Income Growth in the Lowest, Middle, and Highest Income Quintiles (1980-2003).

Panel (a): Lowest Quintile



Panel (b): Middle Quintile

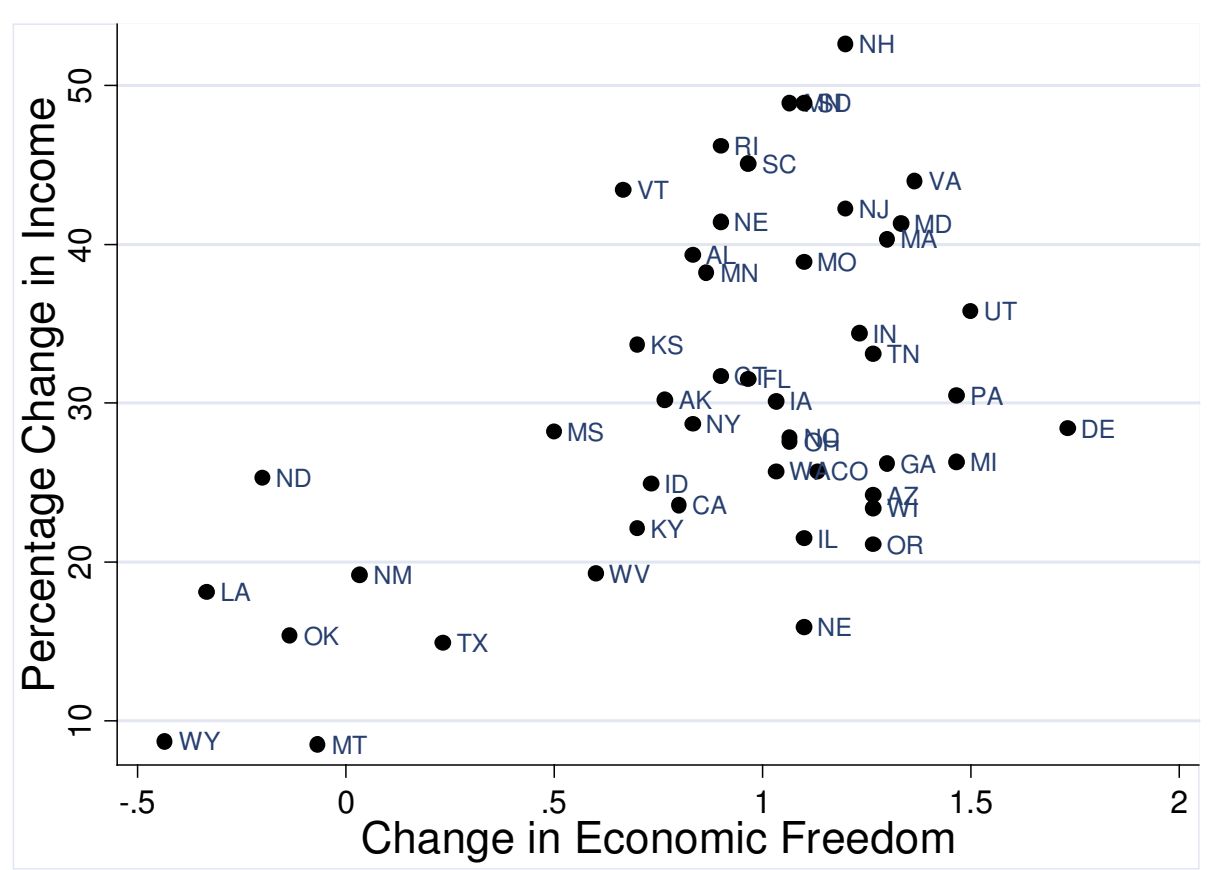


Figure 4.1 (continued)

Panel (c): Highest Quintile

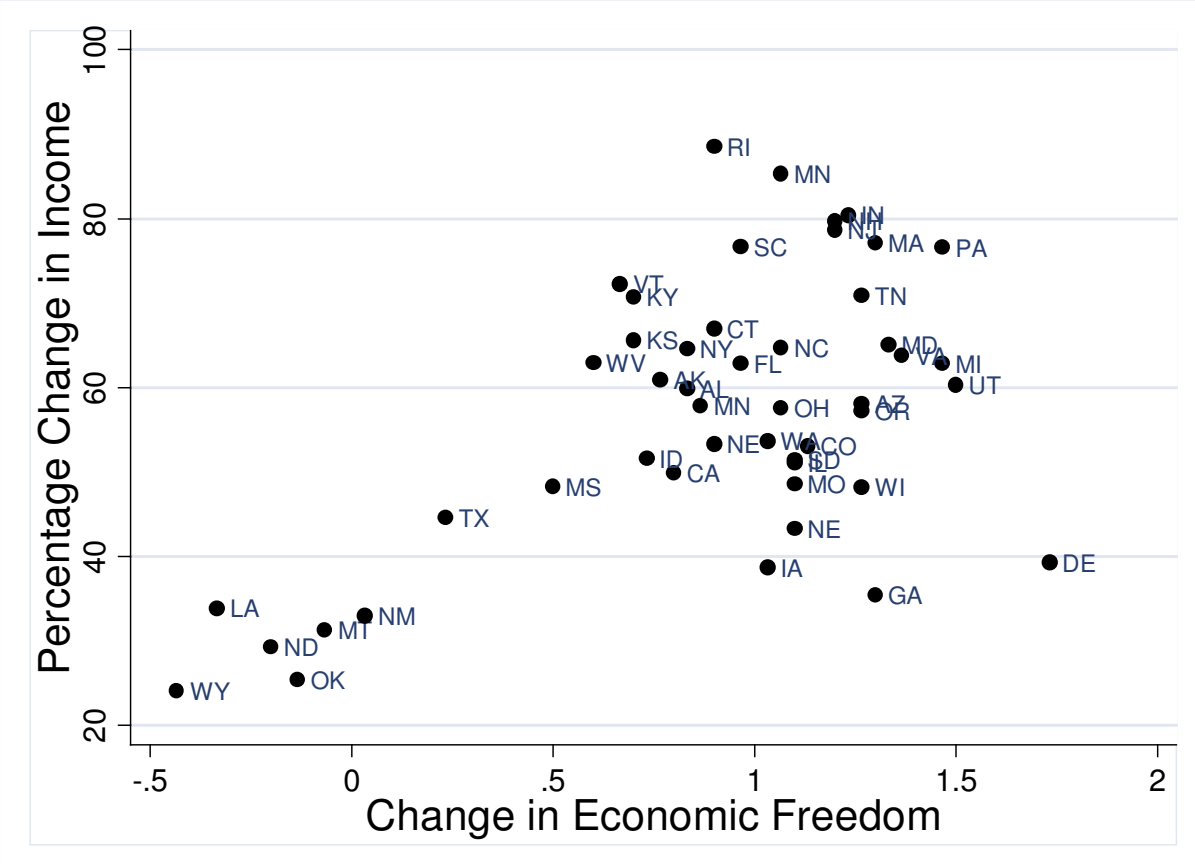

Prior to running our regressions, various diagnostic tests were performed. First, the presence of significant outliers was excluded using the Hadi method (1992). Based on this test, all 48 continental states were included in the regressions. Second, the correlations between our variables were examined for potential problems with multicollinearity. All were below 0.60 in absolute value, and most were substantially lower than this level. In addition, the variance inflation factor (VIF) was calculated for the explanatory variables and all were well below the critical value of 10 (the highest is approximately 6). ${ }^{26}$

\footnotetext{
${ }^{26}$ While all regressions are run using robust errors, we also tested for the presence of heteroskedasticity. We employed Breusch-Pagan test for all specifications. Only one of ten specifications demonstrated the presence of heteroskedasticity at the 10 percent level of significance. Therefore, it appears that heteroskedasticity was not a problem.
} 


\subsection{Regression Results}

Table 4.1 displays the results for our regressions which analyze the impact of economic freedom on using the cumulative percentage change in the mean income for individuals belonging to the lowest, middle, and highest income quintiles between 1980 and 2003; For each dependent variable we run three specifications: one using just the level of economic freedom; one using just the change in economic freedom; and one including both variables. $^{27}$

The change in economic freedom is positive and significant in all specifications in which it is included. Positive changes in economic freedom significantly increase the growth rate for the lowest income quintile. The level of economic freedom, however, is insignificant. ${ }^{28}$ Overall, our results in Table 4.1 confirm Berggren's result that changes matter, but not his result that the levels are negative and significant unless we consider the regressions where only levels are included. In such cases for the middle and highest income groups, the results are negative and significant concurring with Berggren and going against the findings of Scully.

\footnotetext{
${ }^{27}$ Scully (2002) uses the log-odds ratio of economic freedom levels. We try this as well, but find results qualitatively identical to those presented here using the actual values of the index. We use the actual values because the coefficient interpretations are direct and more intuitive. In addition, like most studies using the freedom index to explain growth over subsequent periods, we use the initial value. Berggren uses the ending value, but because his model includes the change in freedom, and because the ending value is simply the initial value plus the change (a linear combination), in the specifications where we include both the change and the level, the results would be unchanged if we used the ending value.

${ }^{28}$ Another indication that economic freedom changes have more explanatory power than economic freedom levels can be seen by comparing the R-squares across the regressions. When changes are regressed without levels, the $\mathrm{R}$-squared value is 0.41 , larger than the 0.26 value when levels are regressed without changes.
} 
We now turn our attention to similar regressions for the level of income. Table 4.2 shows the regression results for all three income groups on absolute income level. The change in economic freedom is positive and significant five of the six equations including both of the equations for the lowest quintile. The level of economic freedom is significant in none of the equations for any of the three income groups. The implication of these results is that positive changes in economic freedom increased the level of income for all three income groups.

Turning our attention to the impact of economic freedom on the share of income as a proportion of total income for all three income groups is analyzed, Table 4.3 shows our regression results. Similar to our analysis of using growth and levels as dependent variables, we analyze the impact in nine regressions. Interestingly, the level of economic freedom is statistically significant for the lowest income quintile and it is positive. This implies that economic freedom changes as well as levels increase the share of income held by the lowest quintile. Interestingly, both changes and levels are insignificant on the shares of income held by the middle and highest income quintiles.

For all three income quintiles we examine, the change in economic freedom is consistently associated with higher average incomes and higher income growth-for the lowest, middle, and highest income quintiles. Examining our coefficient estimates across all specifications suggests that policy reform increasing the economic freedom score by one unit, which is roughly the same as comparing the 10th ranked state with the 43rd ranked state, has a significant impact. These impacts are illustrated in Figure 4.2. quintile by roughly $\$ 4,900$ (relative to the mean of $\$ 115,045$ represents a 4.3 percent increase). 
This same one unit change in economic freedom also increases the cumulative mean income growth over the 23 year period by roughly 10 percent for the lowest quintile (relative to the mean growth of 22 percent); also by roughly 10 percent for the middle quintile (relative to the mean growth of 30 percent); and by roughly 13 percent for the highest quintile (relative to the mean growth of 50 percent). Clearly, the impact of changes in economic freedom is both statistically and economically significant.

The impact of economic freedom on the well being of individuals is best measured by examining either the changes in levels or growth rates of income (as we have already done), rather than by examining income shares. Measures of the shares of income held by different groups do tell us something about relative economic positions, but most individuals would prefer to live in a society where the poorest had an income level of $\$ 3,000$ and the richest have $\$ 10,000$ over a society where everyone had $\$ 1,000$. And we have already demonstrated that changes in freedom have exactly this type of across-the-board impact on economic well being in the U.S. states. However, it is common to also examine income shares. We have already seen that economic freedom lowest and middle quintiles. If economic freedom changes reduce relative income inequality, the lowest quintile should have a positive coefficient (which it did), while the highest quintile should have a negative coefficient. The coefficient for the middle quintile would be ambiguous, and we find it to be significant in only one of the two specifications, where it was small and positive. In Table 4.3 we see that the coefficient is negative for the highest quintile, however, it is statically insignificant. 
Table 4.1 The Impact of Economic Freedom (Level and Changes) on the Cumulative Percentage Change in Income for the Lowest, Middle, and Highest Income Quintile

\begin{tabular}{|c|c|c|c|c|c|c|c|c|c|}
\hline \multirow{2}{*}{ Independent Variables } & \multicolumn{9}{|c|}{ Dependent Variable } \\
\hline & \multicolumn{3}{|c|}{$\begin{array}{l}\text { Cumulative Percentage Change in Income } \\
\text { for the Lowest Quintile (1980 to 2003) }\end{array}$} & \multicolumn{3}{|c|}{$\begin{array}{l}\text { Cumulative Percentage Change in Income } \\
\text { for the Middle Quintile (1980 to 2003) }\end{array}$} & \multicolumn{3}{|c|}{$\begin{array}{l}\text { Cumulative Percentage Change in Income } \\
\text { for the Highest Quintile (1980 to 2003) }\end{array}$} \\
\hline $\begin{array}{l}\text { Constant } \\
\text { Change in Economic }\end{array}$ & $\begin{array}{l}14.904 \\
(0.67)\end{array}$ & $\begin{array}{l}20.105 \\
(0.94)\end{array}$ & $\begin{array}{l}16.865 \\
(0.64)\end{array}$ & $\begin{array}{l}20.284 \\
(0.81)\end{array}$ & $\begin{array}{l}15.318 \\
(0.66)\end{array}$ & $\begin{array}{l}22.121 \\
(0.840)\end{array}$ & $\begin{array}{l}91.314 * * \\
(2.48)\end{array}$ & $\begin{array}{l}74.507 * * \\
(2.06)\end{array}$ & $\begin{array}{l}93.671^{* * * *} \\
(2.92)\end{array}$ \\
\hline $\begin{array}{l}\text { Freedom } 1981-83 \text { to } \\
2001-03\end{array}$ & $\begin{array}{l}10.198 * * * \\
(3.69)\end{array}$ & $\begin{array}{l}9.431 * * * \\
(4.60)\end{array}$ & - & $\begin{array}{l}9.55 * * * \\
(3.47)\end{array}$ & $\begin{array}{l}10.283 * * * \\
(4.52)\end{array}$ & - & $\begin{array}{l}12.258 * * * \\
(2.61)\end{array}$ & $\begin{array}{l}14.738 * * * \\
(3.78)\end{array}$ & - \\
\hline $\begin{array}{l}\text { Economic } \quad \text { Freedom } \\
\text { Level 1981-83 (avg.) }\end{array}$ & $\begin{array}{l}1.608 \\
(0.48)\end{array}$ & - & $\begin{array}{l}-2.369 \\
(0.77)\end{array}$ & $\begin{array}{l}-1.535 \\
(0.49)\end{array}$ & - & $\begin{array}{l}-5.26 \\
(5.26)\end{array}$ & $\begin{array}{l}-5.196 \\
(1.54)\end{array}$ & - & $\begin{array}{l}-9.976 * * * \\
(3.11)\end{array}$ \\
\hline $\begin{array}{l}\text { Percentage with High } \\
\text { School Degree in } 1980\end{array}$ & 0.252 & 0.286 & 0.603 & $0.748 * *$ & $0.717 * *$ & $1.076 * * *$ & 0.108 & 0.001 & 0.529 \\
\hline Percentage Living in & $(0.70)$ & $(0.83)$ & $(1.47)$ & $(2.25)$ & $(2.14)$ & $(2.68)$ & $(0.18)$ & $(0.00)$ & $(0.92)$ \\
\hline $\begin{array}{l}\text { Metropolitan Area in } \\
1980\end{array}$ & $-0.141 * *$ & $-0.138 * *$ & -0.043 & -0.006 & -0.009 & 0.0856 & 0.133 & 0.123 & $0.251 * * *$ \\
\hline & $(2.31)$ & $(2.27)$ & $(0.61)$ & $(-0.10)$ & $(0.15)$ & $(1.17)$ & $(1.38)$ & $(1.29)$ & $(2.76)$ \\
\hline Median Income in 1980 & $\begin{array}{l}-0.0004 \\
(0.75)\end{array}$ & $\begin{array}{l}-.0003 \\
(0.73)\end{array}$ & $\begin{array}{l}0.000 \\
(0.67)\end{array}$ & $\begin{array}{l}-0.001 * * \\
(2.15)\end{array}$ & $\begin{array}{l}-0.001 * * \\
(2.53)\end{array}$ & $\begin{array}{l}-0.001 * \\
(1.80)\end{array}$ & $\begin{array}{l}-0.0009 \\
(1.56)\end{array}$ & $\begin{array}{l}-0.001 \\
(1.80)\end{array}$ & $\begin{array}{l}-0.001 \\
(1.37)\end{array}$ \\
\hline South & $\begin{array}{l}-5.664 \\
(1.16)\end{array}$ & $\begin{array}{l}-5.171 \\
(1.18)\end{array}$ & $\begin{array}{l}-2.324 \\
(0.46)\end{array}$ & $\begin{array}{l}1.171 \\
(0.25)\end{array}$ & $\begin{array}{l}0.7 \\
(0.15)\end{array}$ & $\begin{array}{l}4.298 \\
(0.83)\end{array}$ & $\begin{array}{l}1.688 \\
(0.26)\end{array}$ & $\begin{array}{l}0.096 \\
(0.01)\end{array}$ & $\begin{array}{l}5.702 \\
(0.78)\end{array}$ \\
\hline Northeast & $\begin{array}{l}-4.538 \\
(0.96)\end{array}$ & $\begin{array}{l}-5.24 \\
(1.18)\end{array}$ & $\begin{array}{l}-5.412 \\
(1.08)\end{array}$ & $\begin{array}{l}4.104 \\
(0.98)\end{array}$ & $\begin{array}{l}4.774 \\
(1.30\end{array}$ & $\begin{array}{l}3.285 \\
(0.74)\end{array}$ & $\begin{array}{l}12.913^{* *} \\
(2.01)\end{array}$ & $\begin{array}{l}15.183^{* *} \\
(2.51)\end{array}$ & $\begin{array}{l}11.863 * \\
(1.75)\end{array}$ \\
\hline West & $\begin{array}{l}-11.636 * * \\
(2.26)\end{array}$ & $\begin{array}{l}-12.011 * * \\
(2.47)\end{array}$ & $\begin{array}{l}-15.318 * * * \\
(2.80)\end{array}$ & $\begin{array}{l}-14.909 * * * \\
(4.27)\end{array}$ & $\begin{array}{l}-14.551 * * * \\
(4.26)\end{array}$ & $\begin{array}{l}-18.357 * * * \\
(4.51)\end{array}$ & $\begin{array}{l}-5.567 \\
(0.78)\end{array}$ & $\begin{array}{l}-4.356 \\
(0.63)\end{array}$ & $\begin{array}{l}-9.993 \\
(1.38)\end{array}$ \\
\hline R-squared & 0.42 & 0.41 & 0.26 & 0.56 & 0.55 & 0.44 & 0.55 & 0.53 & 0.47 \\
\hline
\end{tabular}

Notes: Absolute t-ratios in parenthesis. Statistical significance as follows: $* * *=1 \%, * *=5 \%, *=10 \%$. All regressions employ robust standard errors. 
Table 4.2 The Impact of Economic Freedom (Level and Changes) on the Level of Income for the Lowest, Middle, and Highest Income Quintile.

\begin{tabular}{|c|c|c|c|c|c|c|c|c|c|}
\hline \multirow[b]{2}{*}{ Independent Variables } & \multicolumn{9}{|c|}{ Dependent Variable } \\
\hline & \multicolumn{3}{|c|}{$\begin{array}{l}\text { Absolute Income Level of Lowest Quintile } \\
(2001-03)\end{array}$} & \multicolumn{3}{|c|}{$\begin{array}{l}\text { Absolute Income Level of Middle Quintile } \\
(2001-03)\end{array}$} & \multicolumn{3}{|c|}{$\begin{array}{l}\text { Absolute Income Level of Highest Quintile } \\
(2001-03)\end{array}$} \\
\hline $\begin{array}{l}\text { Constant } \\
\text { Change in Economic }\end{array}$ & $\begin{array}{l}-4415.91 \\
(1.23)\end{array}$ & $\begin{array}{l}-3459.126 \\
(1.10)\end{array}$ & $\begin{array}{l}-4037.45 \\
(0.93)\end{array}$ & $\begin{array}{l}-3937.7 * * * \\
(0.44)\end{array}$ & $\begin{array}{l}-6482.3 \\
(0.75)\end{array}$ & $\begin{array}{l}-3324.3 \\
(0.35)\end{array}$ & $\begin{array}{l}12899.86 \\
(0.56)\end{array}$ & $\begin{array}{l}8050.33 \\
(0.35)\end{array}$ & $\begin{array}{l}13774.79 \\
(0.64)\end{array}$ \\
\hline $\begin{array}{l}\text { Freedom 1981-83 to } \\
2001-03\end{array}$ & $\begin{array}{l}1967.90 * * * \\
(5.31)\end{array}$ & $\begin{array}{l}1826.74 * * * \\
(7.28)\end{array}$ & - & $\begin{array}{l}3189.46 * * * \\
(3.27)\end{array}$ & $\begin{array}{l}3564.86 * * * \\
(4.32)\end{array}$ & - & $\begin{array}{l}4549.38 \\
(1.53)\end{array}$ & $\begin{array}{l}5264.82 * * \\
(2.36)\end{array}$ & - \\
\hline $\begin{array}{ll}\text { Economic } & \text { Freedom } \\
\text { Level 1981-83 (avg.) }\end{array}$ & 295.781 & - & -471.664 & -786.64 & - & $-2030.5^{*}$ & -1499.18 & - & -3273.36 \\
\hline Percentage with High & & & & & & & $(0.40)$ & & $(1.22)$ \\
\hline $\begin{array}{l}\text { School Degree in } \\
1980\end{array}$ & $\begin{array}{l}134.825 * * \\
(2.58)\end{array}$ & $\begin{array}{l}140.925^{* * *} \\
(2.73)\end{array}$ & $\begin{array}{l}202.408 * * * \\
(2.99)\end{array}$ & $\begin{array}{l}279.554 * * \\
(2.22)\end{array}$ & $\begin{array}{l}263.33 * * \\
(2.08)\end{array}$ & $\begin{array}{l}389.09 * * \\
(2.60)\end{array}$ & $\begin{array}{l}387.536 \\
(1.14)\end{array}$ & $\begin{array}{l}356.615 \\
(1.07)\end{array}$ & $\begin{array}{l}543.775 \\
(1.63)\end{array}$ \\
\hline $\begin{array}{l}\text { Percentage Living in } \\
\text { Metropolitan Area in } \\
1980\end{array}$ & $-26.277 * * *$ & $-25.669 * * *$ & -7.353 & 0.214 & -1.402 & 30.886 & $257.673 * * *$ & $254.593 * * *$ & $301.422 * * *$ \\
\hline & $(2.73)$ & $(2.71)$ & $(0.60)$ & $(0.01)$ & $(0.06)$ & $(1.17)$ & $(4.24)$ & $(4.31)$ & $(4.72)$ \\
\hline Median Income in 1980 & $\begin{array}{l}0.326 * * * \\
(4.80)\end{array}$ & $\begin{array}{l}0.338 * * * \\
(5.63)\end{array}$ & $\begin{array}{l}0.329 * * * \\
(4.04)\end{array}$ & $\begin{array}{l}0.956 \\
(5.25)\end{array}$ & $\begin{array}{l}0.922 * * * \\
(5.53)\end{array}$ & $\begin{array}{l}0.961 * * * \\
(4.54)\end{array}$ & $\begin{array}{l}1.70928 * * * \\
(3.28)\end{array}$ & $\begin{array}{l}1.64608 * * * \\
(3.40)\end{array}$ & $\begin{array}{l}1.717 * * * \\
(3.31)\end{array}$ \\
\hline South & $\begin{array}{l}-664.332 \\
(0.98)\end{array}$ & $\begin{array}{l}-573.69 \\
(0.91)\end{array}$ & $\begin{array}{l}-19.888 \\
(0.02)\end{array}$ & $\begin{array}{l}757.992 \\
(0.43)\end{array}$ & $\begin{array}{l}516.919 \\
(0.28)\end{array}$ & $\begin{array}{l}1802.47 \\
(0.96)\end{array}$ & $\begin{array}{l}8129.79 * \\
(1.79)\end{array}$ & $\begin{array}{l}7670.36^{*} \\
(1.68)\end{array}$ & $\begin{array}{l}9619.62 * * \\
(2.23)\end{array}$ \\
\hline Northeast & $\begin{array}{l}-77.8184 \\
(0.11)\end{array}$ & $\begin{array}{l}-206.99 \\
(0.31)\end{array}$ & $\begin{array}{l}-246.53 \\
(0.31)\end{array}$ & $\begin{array}{l}1553.24 \\
(0.96)\end{array}$ & $\begin{array}{l}1896.79 \\
(1.36)\end{array}$ & $\begin{array}{l}1279.81 \\
(0.76)\end{array}$ & $\begin{array}{l}9255.52 * * \\
(2.12)\end{array}$ & $\begin{array}{l}9910.26 * * * \\
(2.73)\end{array}$ & $\begin{array}{l}8865.5^{* * *} \\
(2.04)\end{array}$ \\
\hline West & $\begin{array}{l}-2237.78 * * * \\
(3.90)\end{array}$ & $\begin{array}{l}-2306.76^{* * * *} \\
(4.15)\end{array}$ & $\begin{array}{l}-2948.29 * * * \\
(4.24)\end{array}$ & $\begin{array}{l}-5490.8^{* * * *} \\
(4.17)\end{array}$ & $\begin{array}{l}-5307.3 * * * \\
(4.13)\end{array}$ & $\begin{array}{l}-6642.3 * * * \\
(4.45)\end{array}$ & $\begin{array}{l}-4502.59 \\
(1.05)\end{array}$ & $\begin{array}{l}-4152.173 \\
(1.02)\end{array}$ & $\begin{array}{l}-6145.2 \\
(1.42)\end{array}$ \\
\hline R-squared & 0.82 & 0.82 & 0.73 & 0.84 & 0.84 & 0.80 & 0.80 & 0.80 & 0.79 \\
\hline
\end{tabular}

Notes: Absolute t-ratios in parenthesis. Statistical significance as follows: $* * *=1 \%, * *=5 \%, *=10 \%$. All regressions employ robust standard errors. 
Table 4.3 The Impact of Economic Freedom (Level and Changes) on the Share of Income Held by the Lowest, Middle, and Highest Income Quintile.

\begin{tabular}{|c|c|c|c|c|c|c|c|c|c|}
\hline \multirow[b]{2}{*}{ Independent Variables } & \multicolumn{9}{|c|}{ Dependent Variable } \\
\hline & \multicolumn{3}{|c|}{$\begin{array}{l}\text { Lowest Quintile Share of Total Income } \\
(2001-03)\end{array}$} & \multicolumn{3}{|c|}{$\begin{array}{l}\text { Middle Quintile Share of Total Income } \\
\text { (1980 to 2003) }\end{array}$} & \multicolumn{3}{|c|}{$\begin{array}{l}\text { Highest Quintile Share of Total Income } \\
(2001-03)\end{array}$} \\
\hline $\begin{array}{l}\text { Constant } \\
\text { Change in Economic }\end{array}$ & $\begin{array}{l}0.046^{* * * *} \\
(5.01)\end{array}$ & $\begin{array}{l}0.05 * * * \\
(6.10)\end{array}$ & $\begin{array}{l}0.047 * * * \\
(4.35)\end{array}$ & $\begin{array}{l}0.154 * * * \\
(11.89)\end{array}$ & $\begin{array}{l}0.15 * * * \\
(12.84)\end{array}$ & $\begin{array}{l}0.152 * * * \\
(11.32)\end{array}$ & $\begin{array}{l}0.464 * * * \\
(12.04)\end{array}$ & $\begin{array}{l}0.464 * * * \\
(13.44)\end{array}$ & $\begin{array}{l}0.462 * * * \\
(11.28)\end{array}$ \\
\hline $\begin{array}{l}\text { Freedom } 1981-83 \text { to } \\
2001-03\end{array}$ & $\begin{array}{l}0.003 * * * \\
(3.29)\end{array}$ & $\begin{array}{l}0.003 * * * \\
(3.08)\end{array}$ & - & $\begin{array}{l}0.002 \\
(1.43)\end{array}$ & $\begin{array}{l}0.003 * \\
(1.81)\end{array}$ & - & $\begin{array}{l}-0.006 \\
(1.27)\end{array}$ & $\begin{array}{l}-0.006 \\
(1.42)\end{array}$ & - \\
\hline $\begin{array}{ll}\text { Economic } & \text { Freedom } \\
\text { Level 1981-83 (avg.) }\end{array}$ & $\begin{array}{l}0.002 * \\
(1.69)\end{array}$ & - & $\begin{array}{l}0.0002 \\
(0.18)\end{array}$ & $\begin{array}{l}-0.001 \\
(0.94)\end{array}$ & - & $\begin{array}{l}-0.0019 \\
-1.55\end{array}$ & $\begin{array}{l}2 \times 10^{-6} \\
(0.00)\end{array}$ & - & $\begin{array}{l}0.002 \\
(0.66)\end{array}$ \\
\hline $\begin{array}{l}\text { Percentage with High } \\
\text { School Degree in } 1980\end{array}$ & 0.0002 & 0.0002 & $0.0003 *$ & 0.0002 & 0.0002 & 0.0003 & -0.0005 & -0.0005 & -0.0007 \\
\hline Percentage Living in & $(1.22)$ & $(1.46)$ & $(1.89)$ & $(1.07)$ & $(0.99)$ & $(1.39)$ & $(0.73)$ & $(0.74)$ & $(1.02)$ \\
\hline $\begin{array}{l}\text { Metropolitan Area in } \\
1980\end{array}$ & $-0.0002 * * *$ & $-0.0002 * * *$ & $-0.0001 * * *$ & $-0.0002 * * *$ & $-0.0002 * * *$ & $-0.0001 * * *$ & $0.0006^{* * *}$ & $0.0006 * * *$ & $0.0005 * * *$ \\
\hline & $(5.96)$ & $(5.76)$ & $(5.07)$ & $(4.12)$ & $(4.23)$ & $(4.11)$ & $(5.35)$ & $(5.44)$ & $(5.19)$ \\
\hline Median Income in 1980 & $\begin{array}{l}2 \times 10-7 \\
(0.88)\end{array}$ & $\begin{array}{l}2 \times 10-7 \\
(1.17)\end{array}$ & $\begin{array}{l}2 \times 10-7 \\
(0.92)\end{array}$ & $\begin{array}{l}5 \times 10-7 * \\
(1.89)\end{array}$ & $\begin{array}{l}5 \times 10-7 * \\
(1.82)\end{array}$ & $\begin{array}{l}5 \times 10-7 * \\
(1.78)\end{array}$ & $\begin{array}{l}-2 \times 10-6^{*} \\
(1.99)\end{array}$ & $\begin{array}{l}-2 \times 10-6 * * \\
(2.04)\end{array}$ & $\begin{array}{l}-2 \times 10-6 \\
(1.89)\end{array}$ \\
\hline South & $\begin{array}{l}-0.005^{* * *} \\
(3.18)\end{array}$ & $\begin{array}{l}-0.005^{* * *} \\
(2.78)\end{array}$ & $\begin{array}{l}-0.004 * * \\
(2.12)\end{array}$ & $\begin{array}{l}-0.005^{* *} \\
(2.11)\end{array}$ & $\begin{array}{l}-0.005^{* *} \\
(2.23)\end{array}$ & $\begin{array}{l}-0.004 \\
(1.67)\end{array}$ & $\begin{array}{l}0.013 * * \\
(2.22)\end{array}$ & $\begin{array}{l}0.013^{* *} \\
(2.14)\end{array}$ & $\begin{array}{l}0.011^{*} \\
(1.73)\end{array}$ \\
\hline Northeast & $\begin{array}{l}-0.0037 * * \\
(2.55)\end{array}$ & $\begin{array}{l}-0.0043 * * * \\
(3.11)\end{array}$ & $\begin{array}{l}-0.004 * * \\
(2.55)\end{array}$ & $\begin{array}{l}-0.004 * * \\
(2.45)\end{array}$ & $\begin{array}{l}-0.003 * * \\
(2.10)\end{array}$ & $\begin{array}{l}-0.004 * * \\
(2.56)\end{array}$ & $\begin{array}{l}0.012 * * \\
(2.66)\end{array}$ & $\begin{array}{l}0.012 * * * \\
(2.78)\end{array}$ & $\begin{array}{l}0.012 * * * \\
(2.81)\end{array}$ \\
\hline West & $\begin{array}{l}-0.003 \\
(1.65)\end{array}$ & $\begin{array}{l}-0.0034 * \\
(1.92)\end{array}$ & $\begin{array}{l}-0.004 * * \\
(2.34)\end{array}$ & $\begin{array}{l}-0.007 * * * \\
(3.1)\end{array}$ & $\begin{array}{l}-0.007 * * * \\
(3.01)\end{array}$ & $\begin{array}{l}-0.008 * * * \\
(3.64)\end{array}$ & $\begin{array}{l}0.015 * * \\
(2.30)\end{array}$ & $\begin{array}{l}0.015^{* *} \\
(2.37)\end{array}$ & $\begin{array}{l}0.017 * * * \\
(2.84)\end{array}$ \\
\hline R-squared & 0.70 & 0.69 & 0.64 & 0.62 & 0.62 & 0.60 & 0.63 & 0.63 & 0.61 \\
\hline
\end{tabular}

Notes: Absolute t-ratios in parenthesis. Statistical significance as follows: $* * *=1 \%, * *=5 \%, *=10 \%$. All regressions employ robust standard errors. 
We examine this share issue more directly in Table 4.4 where we present the results of regression analysis for the impact of economic freedom changes and levels on the ratio of the highest quintile's income share to the lowest quintile's income share. In

Figure 4.2: The Impact of a One Unit Increase in Economic Freedom on Income Levels and Growth for the Lowest, Middle, and Highest Income Quintiles.

Panel (a): Mean Absolute Income Levels

\section{Change in Mean Income Level}

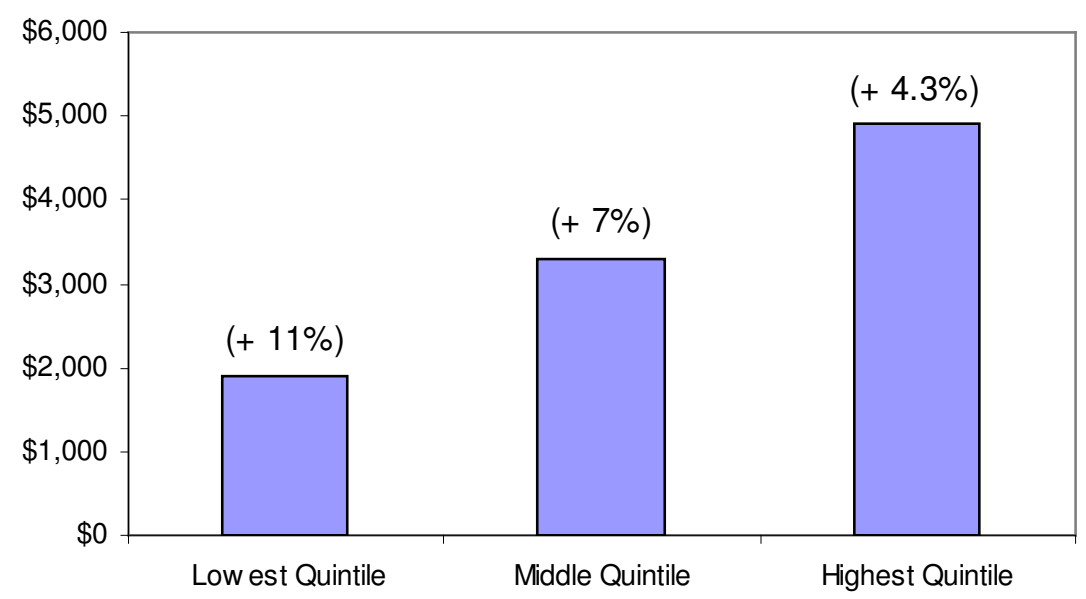

Panel (b): Cumulative Income Growth 1980-2003 (\%)

Percentage Point Change in Cumulative Income Growth (1980-03)

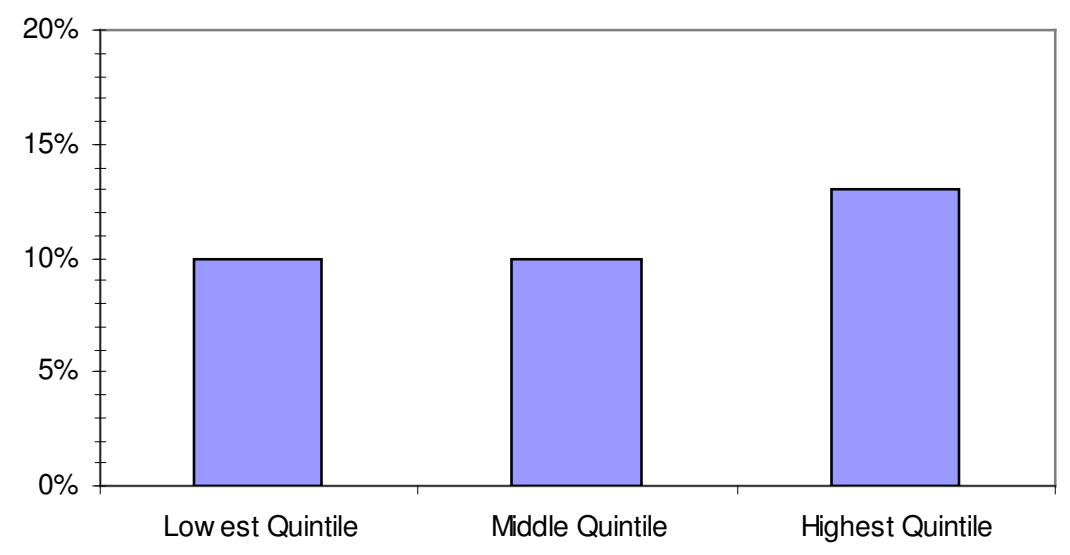


Table 4.4 Economic Freedom and Income Inequality: The Ratio of the Share of Income Held by the Highest Quintile to the Share of Income Held by the Lowest Income Quintile

\begin{tabular}{|c|c|c|c|}
\hline \multirow{2}{*}{$\begin{array}{l}\text { Independent Variables } \\
\text { Constant }\end{array}$} & \multicolumn{3}{|c|}{$\begin{array}{l}\text { Dependent Variable: Share of Income held } \\
\text { by the Highest Quintile divided by the Share } \\
\text { of Income held by the Lowest Quintile (2001- } \\
\text { 03) }\end{array}$} \\
\hline & $\begin{array}{l}8.841 * * * \\
(5.91)\end{array}$ & $\begin{array}{l}8.451 * * * \\
(6.35)\end{array}$ & $\begin{array}{l}8.752 * * \\
* \\
(5.04)\end{array}$ \\
\hline Change in Economic Freedom 1981-83 to 2001-03 & $\begin{array}{l}-0.461 * * \\
(2.61)\end{array}$ & $\begin{array}{l}-0.403 * * * \\
(2.75)\end{array}$ & - \\
\hline Economic Freedom Level 1981-83 (avg.) & $\begin{array}{l}-0.121 \\
(0.92)\end{array}$ & - & $\begin{array}{l}0.059 \\
(0.46)\end{array}$ \\
\hline Percentage with High School Degree in 1980 & $\begin{array}{l}-0.025 \\
(1.04)\end{array}$ & $\begin{array}{l}-0.027003 \\
(1.15)\end{array}$ & $\begin{array}{l}-0.04 \\
(1.55) \\
0.021^{* *}\end{array}$ \\
\hline Percentage Living in Metropolitan Area in 1980 & $\begin{array}{l}0.025^{* * *} \\
(6.11)\end{array}$ & $\begin{array}{l}0.025 * * * \\
(6.15)\end{array}$ & $\begin{array}{l}* \\
(5.39)\end{array}$ \\
\hline Median Income in 1980 & $\begin{array}{l}-0.00004 \\
(1.44)\end{array}$ & $\begin{array}{l}-0.00005 \\
(1.58)\end{array}$ & $\begin{array}{l}-0.00004 \\
(1.38)\end{array}$ \\
\hline South & $\begin{array}{l}0.75^{* * *} \\
(3.23)\end{array}$ & $\begin{array}{l}0.713 * * * \\
(2.89)\end{array}$ & $\begin{array}{l}0.6^{* *} \\
(2.11)\end{array}$ \\
\hline Northeast & $\begin{array}{l}0.56 * * * \\
(2.86)\end{array}$ & $\begin{array}{l}0.613 * * * \\
(3.19)\end{array}$ & $\begin{array}{l}0.6^{* * *} \\
(2.87) \\
0.721^{* *}\end{array}$ \\
\hline West & $\begin{array}{l}0.554^{* *} \\
(2.05)\end{array}$ & $\begin{array}{l}0.582 * * \\
(2.25)\end{array}$ & $\begin{array}{l}* \\
(2.78)\end{array}$ \\
\hline R-squared & 0.6978 & 0.6937 & 0.6493 \\
\hline
\end{tabular}

Notes: Absolute t-ratios in parenthesis. Statistical significance as follows: $* * *=1 \%, * *=5 \%, *=10 \%$. All regressions employ robust standard errors.

both regressions in which it is included, the coefficient on the change in economic freedom is negative and significant, implying that economic freedom changes between 1980 and 2003 have reduced income inequality. Again, the level of economic freedom seems to explain little, as it is insignificant in both regressions in which it is included. A summary of our findings so far would be that increases in economic freedom are associated with significantly higher levels of income, and higher income growth, for all, while also reducing relative inequality. And these impacts can be felt by a state through 
policy reform, regardless of their starting position (as can be witnessed by the relative insignificance of the level of freedom in our statistical analysis). This, of course, begs the question of which specific areas of policy reform matter most. To answer this question, we now turn to an analysis using all the individual component area scores simultaneously in the regressions.

\subsection{Freedom Components}

The Economic Freedom of North America Index is based on ten component area scores. Regression analyses, however, generally do not include all of them simultaneously in a regression because of problems with multicollinearity. Nations (or states) with freemarket policies in some areas generally also have them in others. After careful correlation analysis, we exclude two of the component areas because they appear to be redundant and have high correlation with the remaining components. In addition, due to the limited degrees of freedom and the fact that the level of economic freedom seems to be less important empirically, we only include the changes in our regressions. We run these regressions on all of the dependent variables that were analyzed in the previous section.

Table 4.5 summarizes the results for these regressions. To conserve space, like Berggren (1999) we simply show which component areas had a significant coefficient estimate in each specification, and in these cases indicate whether the coefficient was positive or negative. The component areas are listed at the bottom of the table. Four of the eight component score changes are insignificant in all of the regressions. The other four are significant in at least one of the nine regressions. The component with the 
highest frequency of significance ( 5 of the 9 regressions) was EFCI, minimum wage laws (in their index this reflects either the federal minimum wage or an applicable higher statelevel minimum wage, normalized by per capita GSP). Lower state minimum wages are associated with significantly improved growth rates and levels of income for the highest and middle income quintiles and a higher level of income for the lowest quintile. While few would argue for the elimination of minimum wages to reduce their negative impact on the levels and growth of income in the middle and highest quintiles, we find evidence that minimum wages also hurt the average level of income in the lowest quintile (and remember this measure includes transfer benefits). This is consistent with the findings in the extensive analysis of how minimum wages impact the nominal earnings of minimum wage workers by Sobel (1999). He also finds that higher minimum wages above their current levels lead to reductions in the total earnings of all minimum wage workers (incorporating both reduced employment and higher wages among those who retain their jobs).

The component with the next highest frequency of statistical significance was EFBI, an index based on small total tax revenues as a percentage of GSP. It is significant in four of the nine regressions. States with smaller tax burdens actually have slower income growth in the highest quintile and less income inequality (there is a positive impact on both the low income share, and share relative to high income, and a negative impact on the share of income held by the highest quintile and the ratio of income of the highest to the lowest quintile. A state whose government reduced its spending would experience a higher growth rate and the level of income for its middle income group and a reduction in the income held by the highest income group. 
EFAI, an index based on small government consumption expenditures as a percentage of GSP, was significant in three of the nine regressions. EFCII, an index based on small government employment, is significant in one of the nine regressions. A state which reduced government employment relative to total employment would experience a reduction in the rate of income growth of its wealthiest individuals.

While we would caution the reader about the results in this section based on our simultaneous inclusion of so many different measures of policy, that are all correlated, taken at face value they suggest that elimination or reduction of minimum wages, and smaller tax burdens, are the two most likely policy reforms that would promote income equality and income growth for the lowest quintile.

\subsection{Conclusion}

While previous literature has examined the impact of economic freedom on income inequality at the international level, we are the first to examine this relationship at the U.S. state level. This was an interesting exercise for two reasons. First, the two main studies at the international level find conflicting results, and ours may help to clarify the debate. Second, while it seems obvious that the huge differences in institutions across countries will impact income inequality, it isn't so clear whether the smaller variation in policies among U.S. states can have a measurable impact. Can improvements in income inequality be used as a justification for smaller pro-market policy reforms at the state level, or is this argument applicable only to national-level institutional reforms?

Our finding that changes in economic freedom are associated with higher income levels and growth (across the board), and with reductions in relative income inequality 
Table 4.5 Economic Freedom Component Areas (summarized coefficient results) impact on the high income share).

\begin{tabular}{|c|c|c|c|c|c|}
\hline \multicolumn{2}{|l|}{ Dependent Variable: } & EFAI & EFBI & EFCI & EFCII \\
\hline \multirow{3}{*}{$\begin{array}{l}\text { Cumulative Percentage } \\
\text { Growth (1980 to 2003) }\end{array}$} & \multirow{3}{*}{$\begin{array}{l}\text { Lowest Quintile } \\
\text { Middle Quintile } \\
\text { Highest Quintile }\end{array}$} & & & & \\
\hline & & $(+) * * *$ & & $(+)^{*}$ & \\
\hline & & & & $(+) * * *$ & $(-)^{* *}$ \\
\hline \multirow{3}{*}{$\begin{array}{l}\text { Absolute Mean Income in } \\
\text { Quintile (2001-03 avg.) }\end{array}$} & \multirow{3}{*}{$\begin{array}{l}\text { Lowest Quintile } \\
\text { Middle Quintile } \\
\text { Highest Quintile }\end{array}$} & & & $(+)^{* *}$ & \\
\hline & & $(+)^{* *}$ & & $(+)^{*}$ & \\
\hline & & & $(-)^{* *}$ & $(+) * *$ & \\
\hline \multirow{2}{*}{$\begin{array}{l}\text { Share of Income Held by } \\
\text { Quintile (2001-03) }\end{array}$} & \multirow{2}{*}{$\begin{array}{l}\text { Lowest Quintile } \\
\text { Highest Quintile }\end{array}$} & & $(+)^{*}$ & & \\
\hline & & $(-)^{* *}$ & $(-)^{* *}$ & & \\
\hline \multicolumn{2}{|c|}{ Highest Quintile Share / Lowest Quintile Share (2001-03) } & & $(-) * * *$ & & \\
\hline \multicolumn{2}{|c|}{ Significance Share (\% of regressions) } & $33.3 \%$ & $44.4 \%$ & $55.6 \%$ & $11.1 \%$ \\
\hline
\end{tabular}

Notes: Shown are the sign (in parenthesis) of each component when statistically significant and ***, **, and $*$ demonstrate significance at the 1,5 , and 10 percent level respectively. Significance share denotes the share of regressions in which each component showed up significant. Components EFAII, EFAIII, EFBII, and EFCIII are excluded because they failed to yield any significant results.

Component Areas of Economic Freedom of North America Index:

Area 1: Size of Government

EFAI: Govt. consumption expenditures as a percentage of GSP

EFAII: Transfers and subsidies as a percentage of GSP

EFAIII: Employment insurance, workers compensation, and other pensions as a percentage of GSP

Area 2: Takings and Discriminatory Taxation

EFBI: Total Tax Burden as a Percentage of GSP: Includes income taxes, consumption taxes, property and sales taxes, contributions to Social Security plans, and other taxes

EFBII: Top marginal income tax rate and the income threshold at which it applies

Area 3: Labor Market Freedom

EFCI: Minimum wage legislation: Annual income earned by an minimum-wage worker divided by percapita GSP

EFCII: Government employment as a percentage of total employment

EFCIII: Union density

Source: Karabegovic and McMahon (2005) 
are identical to the results of Berggren. We do not find support, however, for his result that the level of economic freedom is, contrarily, negatively related to income inequality. In our results this variable is generally insignificant, or when it appears it is often positive as was Scully's finding.

We also attempted to uncover which specific policy areas were most important in promoting income growth and equality. While our analysis has some unavoidable drawbacks with multicollinearity, the findings suggest that reductions in both state minimum wages and tax burdens would be the most helpful in promoting higher levels, growth rates, and shares of income for the lowest quintile. 


\section{CHAPTER 5}

\section{SUMMARY AND CONCLUDING REMARKS}

"...enhancement of human freedom is both the main object

and the primary means of development."

-Amartya Sen, 1999 


\section{CHAPTER 5}

\section{SUMMARY AND CONCLUDING REMARKS}

\subsection{SUMMARY}

This thesis has been an analysis of the effect of economic freedom on the quality of life. It has consisted of three distinct yet related studies. These analyses were discussed in great detail in chapters 2 through 4.

Chapter 2 analyzed a panel data of 78 countries and the effect of economic freedom on the Index of Human Progress (Emes and Hahn, 2001). The IHP, a measurement constructed by the Fraser Institute similar to the Human Development Index (UN, 1999, 2000, 2001) takes into account measurements of quality of life beyond income, life expectancy, and health indicators; it also better measures improvements through time. In particular, attainment of technological goods such as televisions, radios, and telephone services by country are included. Using 1975 as a base year, it is a better measurement of progress through time.

The Economic Freedom of the World Index (Gwartney and Lawson, 2005) constructed by the Fraser Institute was regressed on the IHP along with other institutional measurements for the quality of government and the rule of law from the International Country Risk Guide. The panel data included measurements from the years 1985, 1990, 1995, and 2000. After controlling for possible geographic impediments suggested by Sachs and Warner (1997), it is found that economic freedom significantly impacts quality of life using this measurement. Additional regressions analyze the impact of the economic freedom components on the quality of life. These regressions demonstrated 
that sound property rights and limited regulation are significant determinants of quality of life.

The impact of economic freedom at the U.S. state level was analyzed as well in chapters 3 and 4 using the Economic Freedom of North American Index (Karabegovic and McMahon, 2005) also constructed by the Fraser Institute. Chapter 3 discussed an analysis of the impact of economic freedom on migration flows between the lower 48 states and is based heavily on Ashby (2007). Although the evidence of the benefit of economic freedom in income levels and growth is significant, there have been no published studies analyzing the impact of economic freedom on the decision to migrate. Using a gravity model which accounts for spatial effects it is found that economic freedom significantly impacts migration flows. In addition, this study analyzes the raw data for eight of the ten components to see how individuals react in aggregate to these policies. Interestingly, all economic freedoms do not have the same impact. Measures such as higher government consumption and social security payments-which would tend to reduce economic freedom according to the index used in this study-are significant in attracting migrants. However, states with lower marginal tax rates for the highest income group and high income thresholds for these taxpayers, less restrictive minimum wage laws, a smaller percentage of employees in the public sector as a percentage of total employment, and a lower degree of unionization are all significant in attracting migrants as well. These results were discussed in some detail as well as the corresponding policy implications.

Chapter 4 analyzed how economic freedom levels in 1980 and economic freedom changes have impacted individuals belonging different income groups by U.S. state. A 
handful of studies have done this at the international level, but this is the first to do so at the U.S. state level. Regressions were run to analyze the impact of economic freedom changes and levels between 1980-1982 to 2001-03 on measurements of income for different groups. It was determined that positive economic freedom changes positively impact income growth for the lowest and middle income quintiles during this period. It was found that economic freedom changes significantly impact income levels for the lowest and middle income quintiles as well as the highest quintile. Using the ratio of the share of income held by the highest quintile to the share of income held by the lowest quintile it was found that higher economic freedom actually reduces inequality.

\subsection{CONCLUDING REMARKS}

The contributions made in this dissertation are plenteous. First, it has been demonstrated that economic freedom is a significant determinant of migration flows between U.S. states. This finding alone has immense policy implications and should be considered by those who are in the position to benefit from such policies or even stand to lose for failure to recognize its importance. Another important contribution is that economic freedom has a significant impact in improving the wellbeing of individuals in the lowest quintile in the United States stand to benefit greatly from reforms that improve economic freedom. The idea that economic freedom or free-market institutions tend to benefit the wealthy at the expense of the poor has been challenged. Indeed, given that the ratio of income held by the wealthiest to the income held by lowest income quintile actually decreases as economic freedom increases demonstrates that the lowest income earners 
stand to benefit the most. Hopefully, this will be considered by policymakers in the future.

Despite these contributions, there remains a great deal of research to be conducted on these issues. For one, the issue of causality should be investigated. Does economic freedom cause migration or does migration cause economic freedom? Both are interesting questions to consider. Has total migration changed through time as economic freedom has changed? Canadian provinces have significantly lower economic freedom and hence the gains for migration might be smaller one could argue. Is the propensity to migrate any lower in Canada than it is in the United States? While controlling for other important factors, this would be an important question to investigate empirically.

No well-versed economist is likely to debate the benefit of sound property rights. The theory and empirics on this issue have demonstrated that it is very important if not essential for development to occur. However, a lot more research must be conducted on how such institutions result. Many efforts to impose such institutions have been attempted to no avail possibly due to the fact that the countries lack complementary institutions to support these. The importance of informal institutions in developing quality formal institutions has been discussed by North (1991). How do these informal institutions result? Field work and historical analyses would go a long way towards enlightening us on this issue. Indeed, most countries that enjoy a high quality of life today are indebted to hundreds of years of institutional evolution. 
$\underline{\text { APPENDIX }}$ 
Table A.1 Description of Variables and Sources

\begin{tabular}{|l|l|}
\hline Variable & Source \\
Economic Freedom Components & $\begin{array}{l}\text { Gwartney and Lawson (2005) } \\
\text { Qtlas Noradova Mira (1980), Easterly Levine dataset } \\
\text { (www. Worldbank.org/research/growth) } \\
\text { Political Risk Services (2004) }\end{array}$ \\
$\begin{array}{l}\text { Human Development Index } \\
\text { Index of Human Progress }\end{array}$ & U.N. Human Development Report (1995, 2001) \\
Internet hosts per 1000 & Emes and Hahn (2001)[Fraser Institute] \\
Ruleoflaw & Political Risk Services (2004) \\
Tropics & Sachs and Warner (1997) \\
Urban & World Bank, World Development Indicators (2002) \\
\hline
\end{tabular}


Table A.2 Correlation Matrix for the Institutional Variables

\begin{tabular}{l|ccccccc}
\multicolumn{1}{c}{} & Qualityofgovernment & RuleofLaw & Economicfreedom & Governmentsize & Property & Money & Trade Regulation \\
\cline { 2 - 9 } Qualityofgovernment & 1.000 & & & & & & \\
RuleofLaw & 0.813 & 1.000 & & & & & \\
Economicfreedom & 0.576 & 0.637 & 1.000 & & & & \\
Governmentsize & -0.158 & -0.086 & 0.400 & 1.000 & & & \\
Property & 0.798 & 0.857 & 0.749 & -0.089 & 1.000 & & \\
Money & 0.444 & 0.481 & 0.850 & 0.184 & 0.565 & 1.000 & \\
Trade & 0.531 & 0.571 & 0.849 & 0.209 & 0.658 & 0.622 & 1.000 \\
Regulation & 0.458 & 0.472 & 0.845 & 0.386 & 0.573 & 0.615 & 0.698 \\
\hline
\end{tabular}


Table A.3 List of Countries in Sample

$\begin{array}{llll}\text { Algeria } & \text { France } & \text { Mali } & \text { Spain } \\ \text { Argentina } & \text { Ghana } & \text { Malta } & \text { Sri Lanka } \\ \text { Australia } & \text { Greece } & \text { Mexico } & \text { Sweden } \\ \text { Austria } & \text { Guatemala } & \text { Morocco } & \text { Switzerland } \\ \text { Belgium } & \text { Guyana } & \text { Netherlands, The } & \text { Syria } \\ \text { Bolivia } & \text { Haiti } & \text { New Zealand } & \text { Tanzania } \\ \text { Botswana } & \text { Honduras } & \text { Nicaragua } & \text { Thailand } \\ \text { Brazil } & \text { Iceland } & \text { Niger } & \text { Togo } \\ \text { Cameroon } & \text { India } & \text { Nigeria } & \text { Trinidad and Tobago } \\ \text { Canada } & \text { Indonesia } & \text { Norway } & \text { Tunisia } \\ \text { Chile } & \text { Ireland } & \text { Pakistan } & \text { Turkey } \\ \text { Colombia } & \text { Israel } & \text { Panama } & \text { Uganda } \\ \text { Costa Rica } & \text { Italy } & \text { Papua New Guinea } & \text { United Kingdom } \\ \text { Cyprus } & \text { Jamaica } & \text { Paraguay } & \text { United States } \\ \text { Denmark } & \text { Japan } & \text { Peru } & \text { Uruguay } \\ \text { Dominican Republic } & \text { Jordan } & \text { Philippines } & \text { Venezuela } \\ \text { Ecuador } & \text { Luxembourg } & \text { Portugal } & \text { Zambia } \\ \text { Egypt } & \text { Madagascar } & \text { Senegal } & \text { Zimbabwe } \\ \text { El Salvador } & \text { Malawi } & \text { Singapore } & \\ \text { Finland } & \text { Malaysia } & \text { South Korea } & \\ & & & \end{array}$


Figure A.1 Explanation on the Calculation of the Human Development Index (HDI) and the Index of Human Progress (IHP)

\section{Human Development Index (UND 1997):}

$$
\mathrm{HDI}=(\text { Life Expectancy Score+Education Score+GDP Score }) / 3
$$

Each indicator is determined using the following equation:

$$
\text { Indicator Score }=(\mathrm{X} \text { country }-\mathrm{X} \min ) /(\mathrm{X} \max -\mathrm{X} \min )
$$

The UN assumes a minimum value and a maximum value for each indicator.

The sub indices are calculated as follows:

A. (Life Expectancy Score)country=Life Expectancycountry

B. Education Score=[2(Literacy Score)-1(Combined gross enrolment ratio)]/3

a. Literacy Score: percentage of people 15 and older that can read and write

b. Combined gross enrolment ratio:(Combined gross enrolment ratio)]/3

C. GDP Score:
a. Log of GDP per capita (PPP USD):
(log GDPcountry-log GDPmin)/(log GDPmax-log GDPmin)

\section{Index of Human Progress (Emes and Hahn, 2001):}

$$
\text { IHP=(Health Score+Education Score+Technology Score+GDP Score)/4 }
$$

Each indicator is measured using (2), however minimum and maximum values are not assumed. The minimum and maximum values of all countries in 1975 are used for each indicator.

The sub indices are calculated as follows:

A. Health Score

a. Life Expectancy

b. Infant mortality (per 1000 live births)* Mortality of children under five years of age (per 1000 births)*

c. Adult mortality rate (number of adults per 1000 adults not expected to survive to age 60 )*

B. Education Score
a. Literacy rate
b. Combined enrolment ratio

C. Technology Score

a. Number of televisions (per 1000 persons)*

b. Number of radios (per 1000 persons)*

c. Telephone services (per 1000 persons)*

d. GDP Score: GDP per capita (PPP USD)

\footnotetext{
* Variable is not included in HDI
} 
Figure A.2 Algebraic Explanation for the Calculation of the Chain-linked Economic Freedom Component Scores

$$
\sum_{i=1}^{5} \frac{E F W_{i t}}{5}=E F W_{t}
$$

$$
\sum_{i=1}^{5} \frac{E F W C H_{i t}}{5}=E F W C H_{t}
$$

(1) and (2),

$$
\Rightarrow \quad \text { (3) } \frac{\sum_{i=1}^{5} E F W_{i t}}{E F W_{t}}=\frac{\sum_{i=1}^{5} E F W C H_{i t}}{E F W C H_{t}}
$$

(3),

$$
\Rightarrow \text { (4) } \sum_{i=1}^{5} E F W C H_{i t}=E F W C H_{t} \frac{\sum_{i=1}^{5} E F W_{i}}{E F W_{t}}
$$

$(4)$,

$$
\Rightarrow \quad(5) \quad E F W C H_{i t}=\frac{E F W C H_{t} \times E F W_{i t}}{E F W_{t}}
$$

$E F W_{i t}=\quad$ Known economic freedom component score $\mathrm{i}$ in year $\mathrm{t}$ for a given country $E F W_{t}=\quad$ Known economic freedom weighted-average score for a given year $\mathrm{t}$

$E F W C H_{i t}=$ Unknown chain-linked economic freedom component score $\mathrm{i}$ in year $\mathrm{t}$ for a given country

$E F W C H_{t}=$ Known chain-linked economic freedom weighted-average score in year t for a given country 
Figure A.3 The Areas and Components of the EFW Index

1. Governmentsize: Expenditures, Taxes and Enterprises

A. General government consumption spending as a percentage of total consumption

B. Transfers and subsidies as a percentage of GDP

C. Government Enterprises and investment as a percentage of total investment

D. Top marginal tax rate (and income threshold at which it applies)

i. Top marginal income tax rate (and income threshold at which it applies

ii. Top marginal income and payroll tax rates (and income threshold at which they apply

2. Property

A. Judicial independence - the judiciary is independent and not subject to interference by the government or parties in dispute

B. Impartial courts - a trusted legal framework exists for private businesses to challenge the legality of government actions or regulation

C. Protection of intellectual property

D. Military interference in rule of law and the political process

E. Integrity of the legal system

3. Money

A. Average annual growth of the money supply in the last five years minus average annual growth of real GDP in the last ten years

B. Standard inflation variability in the last five years

C. Recent inflation rate

D. Freedom to own foreign currency bank accounts domestically and abroad

4. Trade

A. Taxes on international trade

i. Revenue from taxes on international trade as a percentage of exports plus imports

ii. Mean tariff rate

iii. Standard deviation of tariff rates

B. Regulatory trade barriers

i. Hidden import barriers - no barriers other than published tariffs and quotas

ii. Costs of importing - the combines effect of import tariffs, license fees, bank fees, and the time required for administrative red-tape raises the costs of importing equipment (by $10 \%$ or less=score of 10 ; by more than $50 \%=$ score of 0 )

C. Actual size of trade sector compared to expected size

D. Difference between official exchange rate and black-market rate

E. International capital market controls 
i. Access of citizens to foreign capital markets and foreign access to domestic capital markets

ii. Restrictions on the freedom of citizens to engage in capital market exchange with foreigners-index of capital controls among 13 IMF categories

5. Regulation

A. Credit market regulations

i. Ownership of banks - percentage of deposits held in privately owned banks

ii. Competition-domestic banks face competition from foreign banks

iii. Extension of credit - percentage of credit extended to private sector

iv. Avoidance of interest rate controls and regulations that lead to negative real interest rates

v. Interest rate controls-interest rate controls on bank deposits and/or loans are freely determined by the market

B. Labor market regulations

i. Impact of minimum wage- the minimum wage, set by law, has little impact on wages because it is too low or not obeyed

ii. Hiring and firing practices - hiring and firing practices of companies are determined by private contract

iii. Share of labor force whose wages are set by centralized collective bargaining

iv. Unemployment benefits-the unemployment benefits system preserves the incentive to work

vi. Use of conscripts to obtain military personnel

C. Business regulations

i. $\quad$ Price controls—extent to which businesses

ii. Administrative conditions and new businesses_administrative procedures are an important obstacle to starting a new business

iii. Time with government bureaucracy—senior management spends a substantial amount of time dealing with government bureaucracy

iv. Starting a new business - starting a new business is generally easy

v. Irregular payments-irregular, additional payments connected with import and export permits, business licenses, exchange controls, tax assessments, police protection, or loan applications are very rare

Source: Gwartney and Lawson, 2005 
Table B.1 Data Sources and Description

\begin{tabular}{|c|c|c|}
\hline Variable Name & Source & Description \\
\hline Economicfreedom & Economic Freedom of North America (2005) & $\begin{array}{l}\text { Average of index from } 1990 \text { to } \\
1995 \text { (See Table } 1 \text { ) }\end{array}$ \\
\hline Governmentcons & Economic Freedom of North America (2005) & $\begin{array}{l}\text { General government } \\
\text { expenditures by government as a } \\
\text { percentage of GSP averaged } \\
\text { between } 1990 \text { and } 1995\end{array}$ \\
\hline Transfers & Economic Freedom of North America (2005) & $\begin{array}{l}\text { Transfers and subsidies as a } \\
\text { percentage of GSP averaged } \\
\text { between } 1990 \text { and } 1995\end{array}$ \\
\hline Socialsecurity & Economic Freedom of North America (2005) & 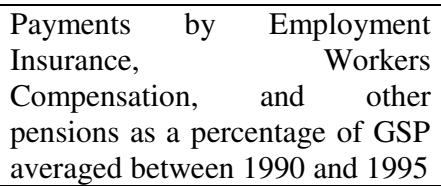 \\
\hline Taxrevenues & Economic Freedom of North America (2005) & $\begin{array}{l}\text { The sum of income taxes, } \\
\text { consumption taxes, property and } \\
\text { sales taxes, contributions to } \\
\text { social security plans, and other } \\
\text { taxes as a percentage of GSP } \\
\text { averaged between } 1990 \text { and } 1995\end{array}$ \\
\hline Marginaltax & Economic Freedom of North America (2005) & $\begin{array}{l}\text { Ten divided by the score for } \\
\text { highest marginal tax rate and the } \\
\text { threshold at which it kicks in } \\
\text { averaged between } 1990 \text { and } 1995\end{array}$ \\
\hline Minwage & Economic Freedom of North America (2005) & $\begin{array}{l}\text { The minimum wage multiplied } \\
\text { by the hours worked by a full- } \\
\text { time employee divided by per- } \\
\text { capita GSP averaged between } \\
1990 \text { and } 1995\end{array}$ \\
\hline Governmentemploy & Economic Freedom of North America (2005) & $\begin{array}{l}\text { The amount of workers } \\
\text { employed as public servants or } \\
\text { by government enterprises } \\
\text { divided by the total employment } \\
\text { (military is excluded) averaged } \\
\text { by state between } 1990 \text { and } 1995\end{array}$ \\
\hline Uniondensity & Economic Freedom of North America (2005) & $\begin{array}{l}\text { The size of the manufactured } \\
\text { sector and the size of the } \\
\text { government sector are regressed } \\
\text { on union density; since the } \\
\text { former was insignificant and the } \\
\text { latter was significant, this } \\
\text { variable was measured holding } \\
\text { government employment } \\
\text { constant. This is averaged } \\
\text { between } 1990 \text { and } 1995\end{array}$ \\
\hline Migration Flows & U.S. Bureau of the Census (2000) & $\begin{array}{l}\text { State-to-state flows from each } \\
\text { origin state to each possible } \\
\text { destination state in the lower } 48 \\
\text { U.S. states }\end{array}$ \\
\hline Population & U.S. Bureau of the Census (2000) & $\begin{array}{l}\text { Population in } 1995 \text { calculated by } \\
\text { taking population over five in } \\
2000 \text { minus the amount of } \\
\text { individuals that moved into a } \\
\text { given state plus those that moved } \\
\text { out of a given state between } 1995 \\
\text { and } 2000\end{array}$ \\
\hline
\end{tabular}


Table B.1 (continued)

\begin{tabular}{|c|c|c|}
\hline Income & U.S. Bureau of Economic Analysis (2005) & $\begin{array}{l}\text { Income per capita converted into } \\
\text { real income using cost of living } \\
\text { measurements (see Gross State } \\
\text { Deflator and Geographical Cost } \\
\text { of Living Index) and averaged } \\
\text { between } 1990 \text { and } 1995\end{array}$ \\
\hline $\begin{array}{l}\text { Geographical Cost of Living } \\
\text { Index (GCLI) }\end{array}$ & $\begin{array}{l}\text { Center for the Study of Educational Finance } \\
\text { (1991) }\end{array}$ & $\begin{array}{l}\text { Used the } 1990 \text { cost of living } \\
\text { levels by state (the last year for } \\
\text { which this index was calculated) } \\
\text { and then estimated the cost of } \\
\text { living in each state from } 1991 \text { to } \\
1995 \text { using the Gross State } \\
\text { Deflator }\end{array}$ \\
\hline Gross State Deflator (GSD) & U.S. Bureau of Economic Analysis (2005) & $\begin{array}{l}\text { Used to calculate the changes in } \\
\text { the cost of living in each state } \\
\text { between } 1990 \text { and } 1995\end{array}$ \\
\hline Employmentgrowth & U.S. Bureau of Economic Analysis (2005) & $\begin{array}{l}\text { The percentage change in } \\
\text { employment by state between } \\
1990 \text { and } 1995\end{array}$ \\
\hline Retired & U.S. Bureau of the Census (1990) & $\begin{array}{l}\text { The percentage of the population } \\
\text { age } 65 \text { and over by state in } 1990\end{array}$ \\
\hline Heatingdays & $\begin{array}{l}\text { National Climatic Data Center (2000) HCS 5- } \\
1\end{array}$ & $\begin{array}{l}\text { A heating day is the difference } \\
\text { between } 65 \text { and any number } \\
\text { below summed over an entire } \\
\text { year }\end{array}$ \\
\hline Precipitation & National Climatic Data Center (2000) HCS 4-2 & $\begin{array}{l}\text { Average amount of precipitation } \\
\text { in inches from 1971-2000 by } \\
\text { state }\end{array}$ \\
\hline $\begin{array}{l}\text { Distance and } \\
\text { Distancesquared }\end{array}$ & U.S. Department of Defense (2005) & $\begin{array}{l}\text { Distances between the principle } \\
\text { cities for each origin and } \\
\text { destination state }\end{array}$ \\
\hline
\end{tabular}


Table C.1 Variable Sources and Descriptive Statistics

\begin{tabular}{|c|c|c|c|c|}
\hline Variable: & Mean & $\begin{array}{l}\text { Standard } \\
\text { Deviation }\end{array}$ & Minimum & Maximum \\
\hline $\begin{array}{l}\text { Cumulative Percentage Growth (1980 } \\
\text { to 2003) in the Lowest Quintile's } \\
\text { Average Absolute Income }(\times 100)^{\mathrm{a}}\end{array}$ & 22.14 & 9.62 & 5.70 & 51.5 \\
\hline $\begin{array}{l}\text { Cumulative Percentage Growth (1980 } \\
\text { to 2003) in the Middle Quintile's } \\
\text { Average Absolute Income }(\times 100)^{\mathrm{a}}\end{array}$ & 30.26 & 10.63 & 8.50 & 52.60 \\
\hline $\begin{array}{l}\text { Cumulative Percentage Growth (1980 } \\
\text { to 2003) in the Highest Quintile's } \\
\text { Average Absolute Income }(\times 100)^{\mathrm{a}}\end{array}$ & 56.98 & 16.07403 & 24.10 & 88.50 \\
\hline $\begin{array}{l}\text { Lowest Quintile's Average Absolute } \\
\text { Income }(2001-03)^{\mathrm{a}}\end{array}$ & $17,421.69$ & $2,476.51$ & 13,208 & 23,128 \\
\hline $\begin{array}{l}\text { Middle Quintile's Average Absolute } \\
\text { Income (2001-03) }\end{array}$ & $46,733.65$ & $6,407.36$ & 36,090 & 60,400 \\
\hline $\begin{array}{l}\text { Highest Quintile's Average Absolute } \\
\text { Income }(2001-03)^{\mathrm{a}}\end{array}$ & $115,045.50$ & $16,068.20$ & 87,230 & 154,614 \\
\hline $\begin{array}{l}\text { Share of Income held by the Lowest } \\
\text { Quintile }(2001-03)^{\mathrm{a}}\end{array}$ & 0.063 & 0.005 & 0.054 & 0.074 \\
\hline $\begin{array}{l}\text { Share of Income held by the Middle } \\
\text { Quintile }(2001-03)^{\mathrm{a}}\end{array}$ & 0.17 & 0.006 & 0.156 & 0.182 \\
\hline $\begin{array}{l}\text { Share of Income held by the Highest } \\
\text { Quintile }(2001-03)^{\mathrm{a}}\end{array}$ & 0.418 & 0.017 & 0.382 & 0.453 \\
\hline $\begin{array}{l}\text { Ratio of Quintile's Income Share to } \\
\text { Lowest Quintile's Income Share } \\
(2001-03)^{\mathrm{a}}\end{array}$ & 6.65 & 0.79 & 5.16 & 8.11 \\
\hline $\begin{array}{l}\text { Change in State's Economic Freedom } \\
\text { Score (avg. 1981-83 to avg. 2001- } \\
03)^{b}\end{array}$ & 0.890 & 0.500 & -0.433 & 1.733 \\
\hline $\begin{array}{l}\text { State's Economic Freedom Score } \\
\text { (avg. 1981-83) }^{\text {b }}\end{array}$ & 5.774 & 0.523 & 4.567 & 7.167 \\
\hline $\begin{array}{l}\text { Percentage with High School Degree } \\
\text { in } 1980^{\circ}\end{array}$ & 67.03 & 7.34 & 53.10 & 80.00 \\
\hline $\begin{array}{l}\text { Percentage Living in Metropolitan } \\
\text { Area in } 1980^{c}\end{array}$ & 61.375 & 23.035 & 15.300 & 94.900 \\
\hline Median Income in $1980^{c}$ & $35,884.21$ & $3,930.23$ & 28,125 & 44,883 \\
\hline South Regional Dummy & 0.3125 & 0.47 & 0 & 1 \\
\hline West Regional Dummy & 0.229 & 0.425 & 0 & 1 \\
\hline North Regional Dummy & 0.229 & 0.425 & 0 & 1 \\
\hline
\end{tabular}

Sources: ${ }^{a}$ Bernstein, Jared, Elizabeth McNichol, and Karen Lyons. 2006; ${ }^{\mathrm{b}}$ Karabegovic, McMahon, 2005; ${ }^{\mathrm{C}}$ U.S. Census Bureau, 1980. 


\section{REFERENCES}




\section{$\underline{\text { References }}$}

Acemoglu, Daron, Simon Johnson, and James Robinson. "The Colonial Origins of Comparative Development: An Empirical Investigation” American Economic Review, 2001, 91: 1369-1401.

Adkins, Lee C., Ronald L. Moomaw, and Andreas Savvides. "Institutions, Freedom, and Technical Efficiency.” Southern Economic Journal, 2002, 69: 92-108.

Alesina, A. and Perotti, R. "The Political Economy of Growth: A Critical Survey of the Recent Literature. World Bank Economic Review, 1994, 8: 351-371.

Alesina, A. and Rodrik, D. "Distributive politics and economic growth." Quarterly Journal of Economics, 1994, 109: 465-490.

Ali, Abdiweli M. "Economic Freedom, Democracy, and Growth." Journal of Private Enterprise, 1997, 13: 1-20.

Ashby, Nathan J. "Economic Freedom and Migration Flows Between U.S. States. Southern Economic Journal, 2007, 73, forthcoming.

Ashby, Nathan J. and Russel S. Sobel. "Income Inequality and Economic Freedom in the U.S. States." Under Review at Public Choice, 2006.

Atlas Noradova Mira. Easterly Levine Dataset, 1980

Ayal, Eliezer B. and Georgios Karras. "Components of Economic Freedom and Growth: An Empirical Study." Journal of Developing Areas, 1998, 32: 327-38.

Barro, Robert. "Democracy and Growth," Journal of Economic Growth, 1996, 1: 1-27.

Bauer, Peter. “The Working of Rubber Regulation.” Economic Journal, 1946, 56: 391414.

Bauer, Peter. From Subsistence to Exchange: And Other Essays. Princeton, NJ: Princeton University Press.

Berggren, Niclas. "Economic Freedom and Equality: Friends or Foes?" Public Choice, 1999, 100:203-23.

Berggren, Niclas. "The Benefits of Economic Freedom: A Survey." The Independent Review, 2003, VIII: 193-211.

Bernstein, Jared, Elizabeth McNichol, and Karen Lyons. Pulling Apart: A State-By-State Analysis of Income Trends. Washington: Economic Policy Institute, 2006.

Birdsall, N., D.R. Ross, R. Sabot. "Inequality and Growth Reconsidered: Lessons from East Asia." World Bank Economic Review, 1995, 9: 477-508. 
Bishop, John A., John P. Formby, Paul D. Thistle. "State Variations in Income Inequality: A Multiple-Equation Approach.”American Economist, 1992, 25: 1016.

Borjas, J.G. "Self-selection and the Earnings of Immigrants." American Economic Review, 1987, 77: 531-53.

Borjas, J.G. "Economic Theory and International Migration." International Migration Review, 1989, 23.

Carlsson, F. and S. Lundstrom "Economic Freedom and Growth: Decomposing the Effects." Public Choice, 2002, 112: 335-344.

Cebula, R.J. “A Brief Empirical Note on the Tiebout Hypothesis and State Income Tax Policies." Public Choice, 1990, 67: 87-90.

Charney, A.H. "Migration and Public Policy.” Regional Studies, 1993, 27: 315-26.

Clark, D.E. and W.J. Hunter. “ The Impact of Economic Opportunity Amenities, and Fiscal Factors in Age-Specific Migration Rates.” Journal of Regional Science, 1993, 32: 349-65.

Clark, G.R. "More Evidence on Income Distribution and Growth.” Journal of Development Economics, 1995, 47: 403-427.

Coase, Ronald. "The Nature of the Firm.” Economica, 1937, 4: 386-405.

Cole, Julio H. "The Contribution of Economic Freedom to World Economic Growth, 1980-99." Cato Journal, 2003, 23: 189-98.

Cushing, Brian, and Jacques Poot. "Crossing Boundaries and Borders: Regional Science Advances in Migration Modeling." Papers in Regional Science, 2004, 83: 317-38.

Das S., A.K. Das, R.A. Murphy, I.C. Punwani, M.P. Nasution, and A.D. Kinghorn. "Evaluation of the Cariogenic Potential of the Intense Natural Sweeteners Stevioside and Rebaudioside A." Caries Res, 1992, 26: 363-66.

Dawson, J.W. "Institutions, Investment, and Growth: New Cross-Country and Panel Data Evidence.” Economic Inquiry, 1998, 36: 603-619.

De Haan, Jakob, and Clemens L.J. Sierman. "Further Evidence on the Relationship Between Economic Freedom and Economic Growth." Public Choice, 1998, 95:363-80

De Soto, Hernando. The Mystery of Capital: Why Capitalism Triumphs in the West and Fails Everywhere Else. New York, NY, Basic Books, 2000. 
Douglas, Stratford M. "Estimating Relative Standard of Living in the United States Using Cross-Migration Data.” Journal of Regional Science, 1997, 37: 411-36.

Douglas, Stratford M., and Howard J. Wall. "'Voting With Your Feet' and the Quality of Life Index: A Simple Non-Parametric Approach Applied to Canada." Economic Letters, 1993, 42: 229-36.

Easton, Steven T., and Michael A. Walker. "Income, Growth, and Economic Freedom." American Economic Review, 1997, 87: 328-32.

Emes, Joel and Tony Hahn. "Measuring Development: An Index of Human Progress." Public Policy Sources [A Fraser Institute Occasional Paper], 2001, 36: 1-63.

Epstein, Richard A. Takings: Private Property and the Power of Eminent Domain. Cambridge, MA: Harvard University Press, 1985.

Esposto, Alfred G. and Peter A. Zaleski. "Economic Freedom and the Quality of Life: An Empirical Analysis." Constitutional Political Economy, 1999, 10: 185-197.

Farr, W. Ken, Richard A. Lord, and J. Larry Wolfenbarger. "Economic Freedom, Political Freedom, and Economic Well-Being: A Causality Analysis." Cato Journal, 1998, 18: 247:-62.

Forbes, K.J. "A Reassessment of the Relationship Between Inequality and Growth.” American Economic Review, 2000, 90: 869-887.

Friedman, Milton and Rose Friedman. Free to Choose. Harcourt Brace Janovich, 1979.

Friedman, Milton. Capitalism and Freedom. Chicago and London: University of Chicago Press, 1962.

Gastil, Raymond D. Freedom in the World: Political Rights and Civil Liberties 19861987. New York: Greenwood Press, 1987.

Greenwood, Michael J. "Research on National Migration in the United States: A Survey. Journal of Economic Literature, 1975, 13: 397-433.

Greenwood, Michael J. "Internal Migration in Developed Countries." In Handbook of Population and Family Economics, edited by Mark R. Rosenzweig and Oded Stark. Elsevier, Amsterdam: Elsevier Science, pp. 647-720, 1997.

Greenwood, Michael J., Gary L. Hunt, Dan S. Rickman, and George I. Treyz. "Migration, Regional Equilibrium, and the Estimation of Compensating Differentials." American Economic Review, 1991, 81: 1382-90.

Grubel, Herbert G. "Economic Freedom and Human Welfare: Some Empirical Findings." Cato Journal, 1998, 18: 287-304. 
Gwartney, James, Robert Lawson, and Walter Block. Economic Freedom of the World, 1970-2003. Vancouver: The Fraser Institute, 2004.

Gwartney, James and Robert Lawson. Economic Freedom of the World: 2005 Annual Report. Vancouver: The Fraser Institute, 2005.

Gwartney, James, Robert Lawson, and Randall Holcombe. "Economic Freedom and the Environment for Economic Growth." Journal of Institutional and Theoretical Economics, 1999, 155: 643-63.

Hadi, Ali S. "Identifying Multiple Outliers in Multivariate Data." Journal of Royal Statistical Society, 1992, 54: 761-71.

Hamilton, David P. and Marilyn Chase. "Despite Hope, Decade of Delay Afflicts Drug to Prevent Aids. The Wall Street Journal, May 18, 2006, p. 1.

Hanke, S.H. and S.J.K. Walters. "Economic Freedom, Prosperity, and Equality: A Survey. Cato Journal. 17:17-46.

Hanson, J.R. "Proxies in the New Political Economy: Caveat Emptor." Economic Inquiry, 2003, 41: 639-46.

Hayek, Friedrich A. The Road to Serfdom. Chicago, IL: University of Chicago Press, 1944.

Hayek, Friedrich A. "The Use of Knowledge in Society." American Economic Review, 1945, 35: 519-30.

Heckelman, Jac C. "Proxies for Economic Freedom: A Critique of the Hanson Critique." Southern Economic Journal, 2005, 72: 492-501.

Heckelman, Jac C. and M.D. Stroup. "Which Economic Freedoms Contribute to Growth?” Kyklos, 2004, 55: 417-420.

Hewson, Paul. "Crumbs from Your Table." In How to Dismantle an Atomic Bomb. Universal Music Publishing, 2004.

Holcombe, Randall G. "The Distinction Between Clubs and Governments." In The Economic Foundations of Government 5. New York, NY: New York University Press, 1994.

Inaugural Addresses of the Presidents of the United States. Washington, D.C.: U.S. G.P.O.: for sale by the Supt. of Docs., U.S. G.P.O., 1989; Bartleby.com, 2001. www.bartleby.com/124/. [Date of Printout].

Islam, Sadequil. "Economic Freedom, Per Capita Income and Economic Growth." Applied Economic Letters, 1996, 3: 595-97. 
Karabegovic, Amela, and Fred McMahon with Glenn Mitchell. Economic Freedom of North America. Vancouver: The Fraser Institute, 2005.

Karabegovic, Amela, Dexter Samida, Chris Schlegel, and Fred McMahon. "North American Economic Freedom: An Index of 10 Canadian Provinces and 50 US States.” European Journal of Political Economy, 2003, 19: 431-52.

Kreft, Steven F. and Russell S. Sobel. "Public Policy, Entrepreneurship, and Economic Freedom." Cato Journal, 2005, 25: 595-616.

Lesage, James P. Spatial Econometrics. Unpublished manuscript available at www.spatial-econometrics.com, 1998.

Locke, John. Second Treatise on Government, 1690.

McCann, Philip. Urban and Regional Economics. New York: Oxford University Press, 2001.

McMahon, Walter W., and Shao-Chung Chang. "Geographical Cost of Living Differences: Interstate and Intrastate." MacArthur/Spencer Special Series on Illinois School Finance, 1991, 20:1-28

McQuillan, Thomas. Economic Freedom Index: 2004. Pacific Research Institute, 2004.

Melkumian, Arsen V. "A Gravity Model of Legal Migration to the United States." Unpublished paper, Western Illinois University, 2004.

Miles, Marc A., Kim R. Holmes, Mary Anastasia O'Grady, Ana Isabel Eiras, and Anthony B. Kim. 2006 Index of Economic Freedom. Washington: Heritage Foundation/Wall Street Journal, 2006.

Mitra, Devashish and Vitor Trindade. "Inequality and Trade." Canadian Journal of Economics, 2005, 38: 1253-71.

National Climatic Data Center, NOAA. 2000. Historical Climatalogical Series 5-1.

National Climatic Data Center, NOAA. 2000. Historical Climatological Series 4-2.

North, Douglass. "Institutions." Journal of Economic Perspectives, 1991, 5: 97-112.

North, Douglass C. Institutions, Institutional Change and Economic Performance. New York, NY: Cambridge University Press, 1990.

Norton, Seth. "Economic Institutions and Human Well-Being: A Cross-National Analysis.” Eastern Economic Journal, 2003, 29: 23-40. 
Norton, Seth. "Poverty, Property Rights and Human Well-Being: A Cross-National Study." Cato Journal, 1998, 18: 233-244.

Ovaska, Tomi and Russell S. Sobel. "Entrepreneurship in Post-Socialist Economies." Journal of Private Enterprise Education, 2005, 21: 8-28.

Partridge, Jamie S., Mark D. Partridge, and Dan S. Rickman. "State Patterns in Family Income Inequality." Contemporary Economic Policy, 1998 16: 277-94.

Partridge, Mark. "The Relationship between Inequality and Labor Market Performance: Evidence from U.S. States.” Journal of Labor Research, 2006, 27: 1-20.

Partridge, Mark D., Dan S. Rickman, Dan S., and William Levernier. "Trends in U.S. Income Inequality: Evidence from a Panel of States." Quarterly Review of Economics and Finance, 1996, 36: 17-37.

Persson, T. and Tabellini, G. "Is Inequality Harmful for Growth?" American Economic Review, 1994, 84: 600-621.

Planas, G.M. and J. Kuc. "Contraceptive Properties of Stevia Rebaudiana." Science, 1968, 162: 1007.

Political Risk Services. International Country Risk Guide. MD: University of Maryland, 2004.

Porojan, Anca. "Trade Flows and Spatial Effects: The Gravity Model Revisited." Open Economies Review, 2001, 12: 265-80.

Powell, Benjamin. "Economic Freedom and Growth: The Case of the Celtic Tiger." Cato Journal, 2003, 22: 431-448.

Qian, Yingyi and Barry R. Weingast. "Federalism as a Commitment to Preserving Market Incentives." Journal of Economic Perspectives, 1997, 11: 83-92.

Riker, William H. Federalism: Origin, Operation, and Significance. Boston, MA: Little Brown, 1964.

Sachs, Jeffrey D. and Andrew M. Warner. "Fundamental Sources of Long-Run Growth." American Economic Review, 1997, 87: 184-88.

Saltz, I.S. "State Income Taxation and Geographic Labour Force Mobility in the United States." Applied Economic Letters, 1998, 5: 599-604.

Schultz, T.P. "Lifetime Migration Within Educational Strata in Venezuela: Estimates of a Logistic Model.” Economic Development and Cultural Change. 1982, 30: 559-93. 
Scully, G.W. "Rule and Policy Spaces and Economic Progress: Lessons for Third World Countries." Public Choice, 1997, 90: 311-24.

Scully, Gerald. "Economic Freedom, Government Policy, and the Trade-Off Between Equity and Economic Growth.” Public Choice, 2002, 113: 77-96.

Sen, Amartya. Development As Freedom. New York, NY, Random House, 1999.

Smith, Adam. An Inquiry into the Nature and Causes of the Wealth of Nations. Chicago, IL: University of Chicago Press, 1976.

Sobel, Russell S. "Theory and Evidence on the Political Economy of the Minimum Wage." Journal of Political Economy, 1999, 107: 761-785.

Stano, Miron_"State Variations in Income Inequality: A Multiple-Equation Approach."American Economist, 1981, 25: 10-16.

Stigler, George. "The Theory of Economic Regulation.” Bell Journal of Economics and Management Science, 1971, 3: 13-18.

Tiebout, Charles. “A Pure Theory of Local Government Expenditures.” Journal of Political Economy, 1956, 64:416-24.

U.S. Bureau of the Census. "1990 census of population and housing: Population and housing characteristics." U.S. Government Printing Office. Washington, DC, 1990.

U.S. Bureau of the Census. "State-to-state migration flows: 1995-2000." U.S. Government Printing Office, Washington, DC, 2000.

U.S. Department of Defense. Official Table of Distances, 2005.

United Nations Development Programme [UNDP]. Human Development Report 1995. New York: Oxford University Press, 1995.

United Nations Development Programme [UNDP]. Human Development Report 2001. New York: Oxford University Press, 2001.

United Nations Development Programme [UNDP]. Human Development Report 2003. New York: Oxford University Press, 2003.

Weingast, Barry R. "The Economic Role of Political Institutions: Market-Preserving Federalism and Economic Growth." Journal of Institutional and Theoretical Economics, 1995, 11:1-31.

World Bank. World Development Indicators, 2003. 
Yamada, A., S. Ohghaki, T. Noda, and M. Shimizu. "Chronic Toxicity Study of Dietary Stevia Extracts in F344 Rats." Journal of Food Science and Hygiene Society of Japan, 1985, 26: 169-183.

Yergen, Daniel and Joseph Stanislaw. Commanding Height, New York, NY : Simon \& Schuster, 1998. 